

\title{
Energy Savings Modeling and Inspection Guidelines for Commercial Building Federal Tax Deductions for Buildings in 2016 and Later
}

Michael Deru and Kristin Field-Macumber National Renewable Energy Laboratory

NREL is a national laboratory of the U.S. Department of Energy Office of Energy Efficiency \& Renewable Energy Operated by the Alliance for Sustainable Energy, LLC

This report is available at no cost from the National Renewable Energy Laboratory (NREL) at www.nrel.gov/publications.

Technical Report

NREL/TP-5500-66774

September 2016 


\title{
Energy Savings Modeling and Inspection Guidelines for Commercial Building Federal Tax Deductions for Buildings in 2016 and Later
}

\author{
Michael Deru and Kristin Field-Macumber \\ National Renewable Energy Laboratory
}

Prepared under Task No. BE4C.2708

NREL is a national laboratory of the U.S. Department of Energy Office of Energy Efficiency \& Renewable Energy Operated by the Alliance for Sustainable Energy, LLC

This report is available at no cost from the National Renewable Energy Laboratory (NREL) at www.nrel.gov/publications.

National Renewable Energy Laboratory 15013 Denver West Parkway Golden, CO 80401

303-275-3000 • www.nrel.gov
Technical Report

NREL/TP-5500-66774

September 2016

Contract No. DE-AC36-08G028308 


\section{NOTICE}

This report was prepared as an account of work sponsored by an agency of the United States government. Neither the United States government nor any agency thereof, nor any of their employees, makes any warranty, express or implied, or assumes any legal liability or responsibility for the accuracy, completeness, or usefulness of any information, apparatus, product, or process disclosed, or represents that its use would not infringe privately owned rights. Reference herein to any specific commercial product, process, or service by trade name, trademark, manufacturer, or otherwise does not necessarily constitute or imply its endorsement, recommendation, or favoring by the United States government or any agency thereof. The views and opinions of authors expressed herein do not necessarily state or reflect those of the United States government or any agency thereof.

This report is available at no cost from the National Renewable Energy Laboratory (NREL) at www.nrel.gov/publications.

Available electronically at SciTech Connect http:/www.osti.gov/scitech

Available for a processing fee to U.S. Department of Energy and its contractors, in paper, from:

U.S. Department of Energy

Office of Scientific and Technical Information

P.O. Box 62

Oak Ridge, TN 37831-0062

OSTI http://www.osti.gov

Phone: 865.576.8401

Fax: 865.576.5728

Email: reports@osti.gov

Available for sale to the public, in paper, from:

U.S. Department of Commerce

National Technical Information Service

5301 Shawnee Road

Alexandria, VA 22312

NTIS http://www.ntis.gov

Phone: 800.553 .6847 or 703.605 .6000

Fax: 703.605.6900

Email: orders@ntis.gov 


\section{Acknowledgments}

This work was funded through the U.S. Department of Energy Building Technologies Office. The authors would like to thank the following individuals for reviewing this and previous versions of this document: Drury Crawley (formerly of the U.S. Department of Energy); Ron Judkoff, Paul Torcellini, Dennis Barley (formerly of NREL), Shanti Pless, Otto Van Geet, Ramin Faramarzi, and James Salasovich of NREL; Brent Griffith (formerly of NREL); Jennifer Bernardini of the Internal Revenue Service; and Philip Fairey and Muthusamy Swami of the Florida Solar Energy Center. 


\section{Executive Summary}

The Internal Revenue Code $\S 179 \mathrm{D}$ provides for a federal tax deduction of $\$ 1.80$ per square foot for installation of energy-efficient technologies in new or existing buildings. The tax deduction is available to building owners for installation of (1) interior lighting; (2) building envelope, or (3) heating, cooling, ventilating, or hot water systems that reduce the building's total energy and power costs equal to the levels presented in Table ES-1 in comparison to a building meeting minimum requirements set by ASHRAE Standard 90.1-2007. The energy and power cost savings must be calculated following the guidance provided in this document using qualified software as determined by the U.S Department of Energy.

This document provides updated guidance for modeling and inspecting energy-efficient property in commercial buildings as enacted by the Protecting Americans from Tax Hikes (PATH) Act of 2015. This document applies to buildings placed in service on or after January 1, 2016.

Table ES-1. Summary of Savings Requirements and Tax Deductions

\begin{tabular}{|c|c|c|c|c|c|}
\hline & \multirow{2}{*}{$\begin{array}{l}\text { Fully } \\
\text { Qualifying } \\
\text { Property }\end{array}$} & \multicolumn{4}{|c|}{ Partially Qualifying Property } \\
\hline & & Envelope & $\begin{array}{l}\text { HVAC and } \\
\text { SHW }\end{array}$ & Lighting & $\begin{array}{c}\text { Interim Lighting } \\
\text { Rule }\end{array}$ \\
\hline $\begin{array}{l}\text { Savings } \\
\text { Requirements }\end{array}$ & $\begin{array}{l}50 \% \text { energy } \\
\text { and power } \\
\text { cost savings }\end{array}$ & $\begin{array}{l}10 \% \text { energy } \\
\text { and power } \\
\text { cost savings }\end{array}$ & $\begin{array}{l}15 \% \text { energy } \\
\text { and power cost } \\
\text { savings }\end{array}$ & $\begin{array}{l}25 \% \text { energy } \\
\text { and power cost } \\
\text { savings }\end{array}$ & $\begin{array}{l}25 \%-40 \% \text { lower } \\
\text { LPD (50\% for } \\
\text { warehouses) }\end{array}$ \\
\hline Tax Deduction & $\begin{array}{l}\text { Cost of } \\
\text { qualifying } \\
\text { property up } \\
\text { to } \$ 1.80 / \mathrm{ft}^{2}\end{array}$ & $\begin{array}{l}\text { Cost of } \\
\text { qualifying } \\
\text { property up } \\
\text { to } \$ 0.60 / \mathrm{ft}^{2}\end{array}$ & $\begin{array}{l}\text { Cost of } \\
\text { qualifying } \\
\text { property up to } \\
\$ 0.60 / \mathrm{ft}^{2}\end{array}$ & $\begin{array}{l}\text { Cost of } \\
\text { qualifying } \\
\text { property up to } \\
\$ 0.60 / \mathrm{ft}^{2}\end{array}$ & $\begin{array}{l}\text { Cost of qualifying } \\
\text { property up to } \\
\$ 0.60 / \mathrm{ft}^{2} \text { times } \\
\text { applicable } \\
\text { percentage }^{\mathrm{b}}\end{array}$ \\
\hline
\end{tabular}

a Savings refer to the reduction in the energy and power costs of the combined energy for only the interior lighting, HVAC, and SHW systems as compared to those of a reference building that meets the minimum requirements of Standard 90.1-2007.

b The tax deduction varies linearly from $\$ 0.30 / \mathrm{ft}^{2}$ to $\$ 0.60 / \mathrm{ft}^{2}$ with the reduction in LPD from $25 \%$ to $40 \%$. See IRS Notice 2006-52 (IRS 2006) for the definition of "applicable percentage." 


\section{Table of Contents}

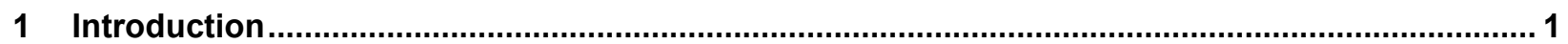

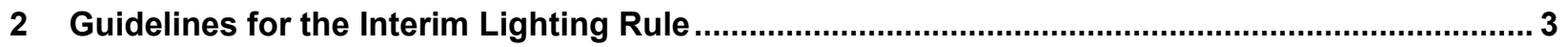

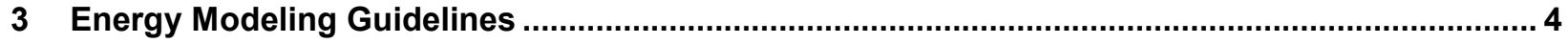

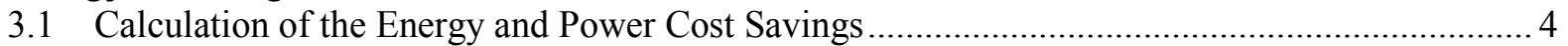

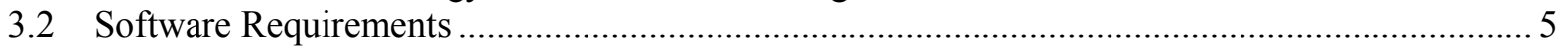



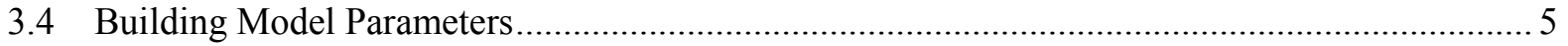

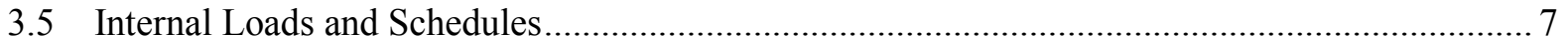



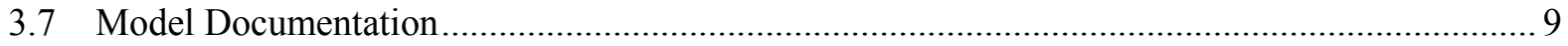

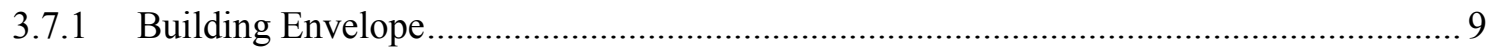

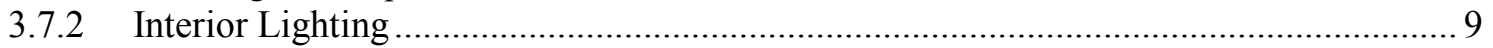





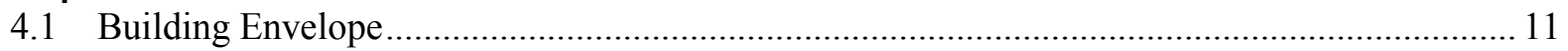

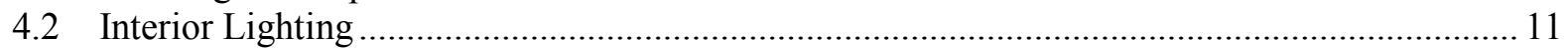

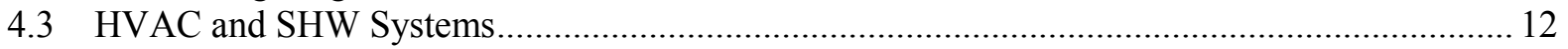

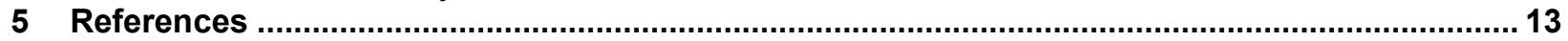

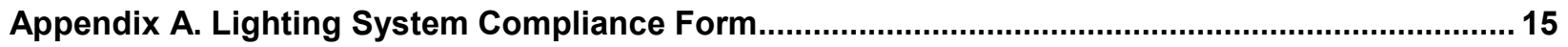

Appendix B. Infiltration Modeling Rules from the 2005 California Nonresidential ACM Approval

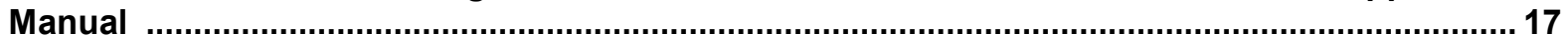
Appendix C. Internal Loads and Schedules from the 2005 California Nonresidential ACM Approval

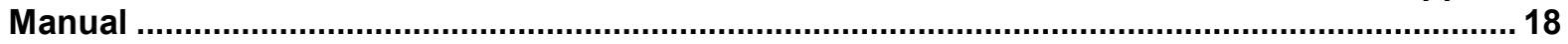

Appendix D. Illuminance Categories and Luminaire Power from the 2005 California Nonresidential

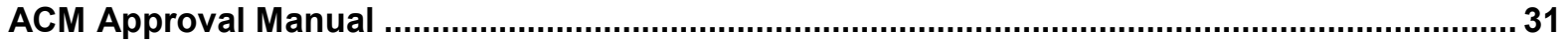




\section{List of Tables}

Table ES-1. Summary of Savings Requirements and Tax Deductions ............................................. iv

Table 1. Summary of Savings Requirements and Tax Deductions ................................................ 2

Table 2. Building and Model Descriptions.................................................................................... 4

Table 3. Summary of Building Modeling Parameters for a Fully Qualifying Building ......................... 6

Table A-1. Illuminance Levels (Table LF1 from Deru 2007) ............................................................. 16

Table A-2. Lighting Controls Description in the Proposed Building Energy Model (Table LF2 from



Table A-3. Lighting Controls Description in the Taxpayer's Building (Table LF3 from Deru 2007) . 16

Table A-4. Additional Lighting Systems Mandatory Provisions Checklist for the Interim



Table B-1. Insert Table Caption Here ............................................................................................ 17

Table C-1. Occupancy Assumptions When Lighting Plans are Submitted for the Entire Building or When Lighting Compliance Is Not Performed (Table N2-2 from CEC 2004) .............................. 18

Table C-2. Area Occupancy Assumptions When Lighting Plans are Submitted for Portions or for the Entire Building or When Lighting Compliance is Not Performed (Table N2-3 from CEC 2004)

Table C-3. Schedule Types of Occupancies and Sub-Occupancies (Table N2-4 from CEC 2004) ... 24

Table C-4 (CEC 2004, Table C-4. Nonresidential Occupancy Schedules (Other than Retail) (Table N2-5 from CEC 2004)

Table C-5. Hotel Function Occupancy Schedules (Table N2-6 from CEC 2004)............................... 27

Table C-6. Residential Occupancy Schedules (Including Hotel/Motel Guest Rooms) with Setback Thermostat for Heating (Table N2-7 from CEC 2004).................................................................. 28

Table C-7. Residential Occupancy Schedules (Including Hotel/Motel Guest Rooms) without Setback Thermostat (Table N2-8 from CEC 2004)

Table C-8. Retail Occupancy Schedules (Table N2-9 from CEC 2004) ........................................... 30 


\section{Introduction}

This document provides guidance for modeling and inspecting energy-efficient property in commercial buildings for determining the energy and power cost savings related to $\S 179 \mathrm{D}$ of the Internal Revenue Code (IRC). The tax deduction was enacted in $\S 1331$ of the 2005 Energy Policy Act (EPAct) of 2005, noted in Internal Revenue Service (IRS) Notices 2006-52 (IRS 2006), 2008-40 (IRS 2008) and 2012-26 (IRS 2012), and updated by the Protecting Americans from Tax Hikes (PATH) Act of 2015. Specifically, § 179D provides federal tax deductions for energy-efficient property related to a commercial building's envelope; interior lighting; heating, ventilating, and air conditioning (HVAC); and service hot water (SHW) systems. This document applies to buildings placed in service on or after January 1, 2016. See the Energy Savings Modeling and Inspection Guidelines for Commercial Building Federal Tax Deductions, Second Edition (Deru 2007) for modeling the energy and power cost savings of buildings placed in service before January 1, 2016.

The qualification levels and tax deductions under $\S 179 \mathrm{D}$ are summarized in Table 1. A fully qualifying property saves at least $50 \%$ in energy and power costs for improvements in the envelope, lighting, HVAC, and SHW systems compared to a reference building that meets the minimum requirements of ANSI/ASHRAE/IESNA ${ }^{1}$ Standard 90.1-2007. The PATH Act of 2015 expresses Standard 90.1-2007 as "Standard 90.1-2007 of ASHRAE and IESNA (as in effect on the day before the date of the adoption of Standard 90.1-2010 of such Societies)." This definition includes 90.1-2007 and the Addenda Supplement Package (Addenda a, b, c, g, h, i, j, k, 1, m, n, p, $\mathrm{q}, \mathrm{s}, \mathrm{t}, \mathrm{u}, \mathrm{w}, \mathrm{y}, \mathrm{ad}$, and aw) and Addendum r, plus all published errata. A partially qualifying property saves at least the percentages shown in Table 1 for energy and power costs through efficiency improvements in any one of envelope, lighting, or HVAC and SHW. The energy and power cost savings are determined for the energy use in only the interior lighting, HVAC, and SHW systems (e.g., not for miscellaneous or process equipment savings). An alternative option for partially qualifying buildings is the interim lighting rule, which allows the tax deduction to be based on reductions in the interior lighting power density (LPD).

Additions to existing buildings or alterations to existing buildings can qualify for tax deductions in the new or retrofitted areas of the building only. The savings requirements are relative to a reference building that meets the minimum requirements of Standard 90.1-2007, and they are not relative to the performance of the existing building.

The taxpayer must obtain certification of the savings from the energy-efficient property to qualify for the federal tax deductions. The certification requirements are defined in Section 4 of IRS Notice 2006-52 (IRS 2006). The certification process includes calculation of the energy and power cost savings and inspection of the energy-efficient property by a qualified individual, as defined in Notice 2006-52 (IRS 2006). Use the Performance Rating Method from Appendix G of Standard 90.1-2007 with the additional guidance presented in Section 3 of this document to compute the energy and power cost savings. Section 4 of this document provides guidance for the inspection of the energy-efficient property.

\footnotetext{
${ }^{1}$ ANSI= American National Standards Institute, IESNA = Illuminating Engineering Society of North America
} 
Table 2. Summary of Savings Requirements and Tax Deductions

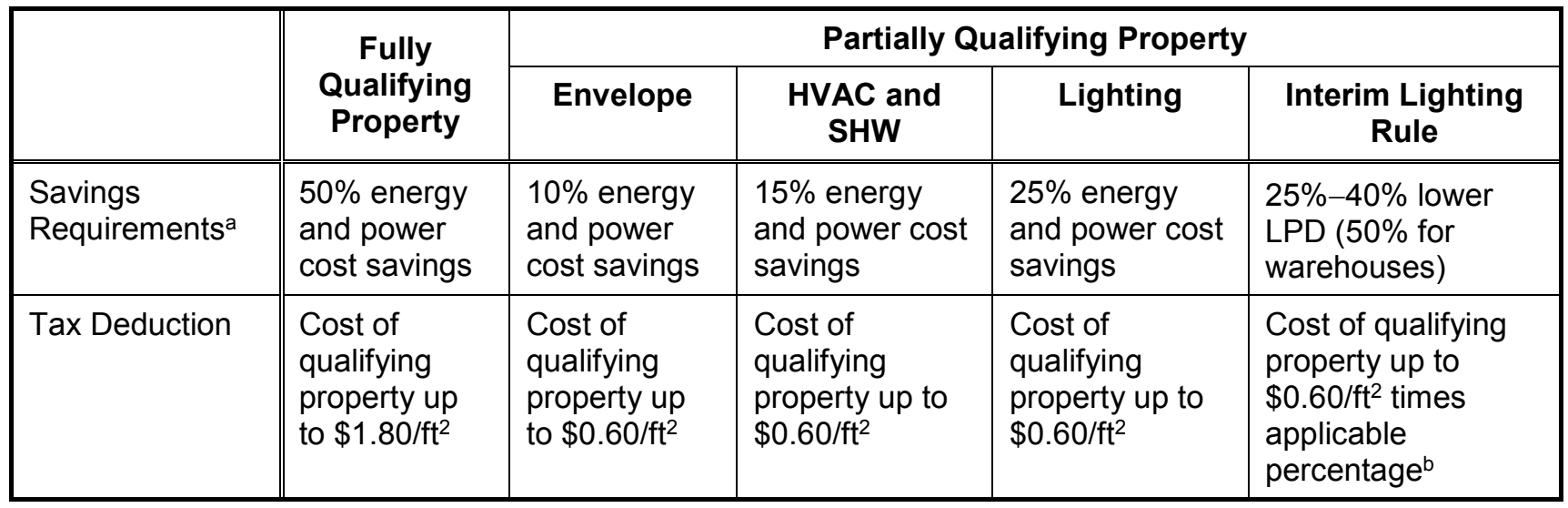

a Savings refer to the reduction in the energy and power costs of the combined energy for only the interior lighting, HVAC, and SHW systems as compared to those of a reference building that meets the minimum requirements of Standard 90.1-2007.

b The tax deduction varies linearly from $\$ 0.30 / \mathrm{ft}^{2}$ to $\$ 0.60 / \mathrm{ft}^{2}$ with the reduction in LPD from $25 \%$ to $40 \%$. See IRS Notice 2006-52 (IRS 2006) for the definition of "applicable percentage." 


\section{Guidelines for the Interim Lighting Rule}

This section provides guidance for the tax deduction under the interim lighting rule in $\S$ 179D of the IRC. The interim rule states that the LPD must be reduced at least $25 \%$ ( $50 \%$ for warehouses) from the values in Standard 90.1-2007, Tables 9.5.1 or 9.6.1. The building-area method or the space-by-space method can be used to determine the LPD reduction in accordance with Standard 90.1-2007 Sections 9.5 or 9.6. The bi-level switching requirement from EPAct 2005 applies to both new and existing building projects. ${ }^{2}$

To qualify for the tax deduction using the interim lighting rule, document the reduction in LPD for each building area and/or space and conduct a physical inspection of the taxpayer's building. The documentation may be completed on any form, spreadsheet, or other software that shows the Standard 90.1-2007 requirements and the reduced LPDs. The mandatory control and minimum illuminance requirements must be documented upon physical inspecting the taxpayer's building following these steps:

1. Document that the taxpayer's building meets or exceeds the mandatory provisions of the Standard 90.1-2007 using the Standard 90.1-2007 Lighting Compliance form or an equivalent form. The Standard 90.1-2007 compliance forms can be downloaded from ASHRAE Standards Forms website (ASHRAE 2016).

2. Document the installed LPD on the Standard 90.1-2007 Lighting Compliance form or equivalent form and ensure the documented LPD is equal to or lower than the allowable LPD per Standard 90.1-2007.

3. Document the IESNA minimum illuminance levels for horizontal surfaces (25-65 years old) from the Illuminating Engineering Society of North America (IESNA) Lighting Handbook Tenth Edition (IESNA 2011) and measured illuminance levels either (1) in Table A-1 (Appendix A), which is reproduced in Appendix A of this document or (2) on an equivalent form. Record the average of measurements taken on the working surfaces or at the locations listed in the IESNA handbook (IESNA 2011). The measured average values must equal or exceed the IESNA-recommended minimum illuminance levels. In addition, no more than $2.5 \%$ of the measurements may be below one-third of the IESNArecommended minimum illuminance levels; this latter requirement assumes a normal distribution of data points, with two standard deviations from the measurements equal to one-third of the recommended illuminance level. Measurements need be completed only once for each unique space and lighting arrangement.

4. Verify that the bi-level switching requirement under the interim rule for lighting systems is met and documented in Table A-4 (Appendix A) or on an equivalent form.

\footnotetext{
${ }^{2}$ Bi-level switching is defined as some combination of manual control, automatic control, or combination of the two that provides two levels of lighting power (not including off) in a space. Occupancy sensors that turn all the lights off in a space do not qualify as bi-level switching. Occupancy sensors that dim or turn off only some lights in a space do satisfy the bi-level switching requirement.
} 


\section{Energy Modeling Guidelines}

For tax deductions not using the interim lighting rule, the energy and power cost savings of the taxpayer's building are determined from annual hourly energy simulations of a proposed building model and a reference building model. Table 2 provides descriptions of the building models. The energy modeling must be completed in accordance with the Performance Rating Method presented in Appendix G of ANSI/ASHRAE/IESNA Standard 90.1-2007 with the exception noted in this section.

For additions or alterations to existing buildings, model just the portions of the building affected by the changes with appropriate modeling methods to account for connections to the unaltered portions of the building. The envelope, interior lighting, HVAC, and SHW in the reference building model shall meet the minimum requirements of Standard 90.1-2007.

Table 3. Building and Model Descriptions

\begin{tabular}{|l|l|}
\hline Building/ Model & Description \\
\hline \hline Taxpayer's building & Physical building used for the tax deduction \\
\hline Reference building model & $\begin{array}{l}\text { Computer simulation model that matches the taxpayer's building except } \\
\text { that the interior lighting systems, HVAC, SHW, and building envelope } \\
\text { comply with the minimum requirements of Standard 90.1-2007 }\end{array}$ \\
\hline Proposed building model & $\begin{array}{l}\text { Computer simulation model that is identical to the reference building } \\
\text { model except for the systems that are qualifying for the tax deduction }\end{array}$ \\
\hline
\end{tabular}

a The systems qualifying for the tax deduction shall match the systems in the taxpayer's building. This model might not represent the taxpayer's building exactly because the systems not qualifying for the tax deduction will be compliant with the minimum requirements in Standard 90.1-2007.

\subsection{Calculation of the Energy and Power Cost Savings}

The energy and peak demand for the interior lighting, HVAC, and SHW systems, as calculated from the hourly annual energy simulations, are used to determine the energy and power cost savings. Receptacle, process, and other loads are included in the energy simulations, but the energy and power costs associated with these loads are not included in the savings calculation. Determining the power cost savings requires knowing the power consumption for the whole building and for the interior lighting, HVAC, and SHW systems at the time of the building peak demand for each month. Power costs are defined as the monthly peak demand charges and associated taxes and fees.

To calculate the annual energy and power costs:

- Use the same utility rate structure for the proposed building and the reference building models.

- Use the utility rate structure that applies to the taxpayer's building or the state average commercial building utility rates published by the Energy Information Administration (EIA 2016). If energy is provided to the building at no cost or the building does not have its own utility billing, use the utility tariffs that would apply if the building were billed independently. 
- Include all utility costs in the calculations. Monthly fixed fees should be divided between the energy and power cost totals, based on the ratio of these costs.

- Do not include on-site renewable energy generation of electricity that is connected to the building electrical system in the energy simulations or in the energy and power cost calculations.

- Solar hot water systems can be included as part of the HVAC or the SHW systems. However, if the solar hot water system was used for a different federal tax deduction, it cannot be used again for a tax deduction under $\S 179 \mathrm{D}$ of the IRC.

- If possible, set up the simulation software to calculate energy and power costs for just the interior lighting, HVAC, and SHW systems for all energy types (e.g., electricity and gas) to determine savings.

- If the simulation software cannot calculate energy and power costs separately from the whole building, record the monthly energy and peak demand totals by end use and calculate the energy and power costs for each month. Be sure to include all energy and demand charges that occur due to seasonal rates, ratcheting, block charges, time-of-use rates, or other pricing structures.

\subsection{Software Requirements}

The same software and version number must be used to model the reference building and the proposed building, and the software must be included (at the time the certification is given) on the list of qualified software published by the U.S. Department of Energy (DOE n.d.). Use the qualified versions of software for buildings placed in service on or after January 1, 2016.

\subsection{Weather Data}

The energy simulations of the reference building and the proposed building models must use the same annual hourly weather file and the same design day weather conditions. The annual weather file must represent a typical meteorological year (TMY) for the taxpayer's building location. The weather file should be selected from the climate zone that most closely represents the typical weather conditions at the location of the taxpayer's building; this may or may not be the weather file for the location closest to the taxpayer's building. Many simulation programs provide specially formatted versions of the TMY2, TMY3, or other similar weather files for use with their programs. The TMY and California climate zone (CTZ2) weather files are available from the EnergyPlus website (EnergyPlus n.d.).

The design day weather data used for sizing equipment shall represent the $99.6 \%$ annual cumulative frequency dry-bulb temperature for heating conditions and the $1 \%$ annual cumulative frequency dry-bulb and wet-bulb temperatures for cooling conditions. Design day weather data is available in ANSI/ASHRAE Standard 169-2013 (ASHARE 2013a) and ASHRAE Handbook of Fundamentals 2013 (ASHRAE 2013b).

\subsection{Building Model Parameters}

As defined in Table 2, the reference building model represents the taxpayer's building except that the envelope, interior lighting, HVAC, and SHW must comply with the minimum 
requirements of Standard 90.1-2007. And, the proposed building model is identical to the reference building model, except that the building systems used for the tax deduction must match the taxpayer's building. Table 3 shows the main energy modeling parameters of the two models.

Table 4. Summary of Building Modeling Parameters for a Fully Qualifying Building

\begin{tabular}{|c|c|c|}
\hline Parameter & Reference Building Model & $\begin{array}{l}\text { Proposed Building } \\
\text { Model }\end{array}$ \\
\hline Location & Same as taxpayer's building & $\begin{array}{l}\text { Same as reference } \\
\text { building model }\end{array}$ \\
\hline Utility rate structure & $\begin{array}{l}\text { Same as taxpayer's building (see Section } 3.1 \text { of this } \\
\text { document) }\end{array}$ & $\begin{array}{l}\text { Same as reference } \\
\text { building model }\end{array}$ \\
\hline $\begin{array}{l}\text { Annual weather } \\
\text { data }\end{array}$ & $\begin{array}{l}\text { Typical year weather file (see Section } 3.3 \text { of this } \\
\text { document) }\end{array}$ & $\begin{array}{l}\text { Same as reference } \\
\text { building model }\end{array}$ \\
\hline $\begin{array}{l}\text { Design day } \\
\text { weather data }\end{array}$ & See Section 3.3 of this document. & $\begin{array}{l}\text { Same as reference } \\
\text { building model }\end{array}$ \\
\hline $\begin{array}{l}\text { Form (area, shape, } \\
\text { floors) }\end{array}$ & Same as taxpayer's building & $\begin{array}{l}\text { Same as reference } \\
\text { building model }\end{array}$ \\
\hline Envelope & 90.1-2007 minimum requirements & $\begin{array}{l}\text { Same as taxpayer's } \\
\text { building }\end{array}$ \\
\hline Interior lighting & 90.1-2007 minimum requirements & $\begin{array}{l}\text { Same as taxpayer's } \\
\text { building }\end{array}$ \\
\hline HVAC systems & 90.1-2007 minimum requirements & $\begin{array}{l}\text { Same as taxpayer's } \\
\text { buildinga }^{\text {a }}\end{array}$ \\
\hline SHW systems & 90.1-2007 minimum requirements & $\begin{array}{l}\text { Same as taxpayer's } \\
\text { building }^{\text {a }}\end{array}$ \\
\hline $\begin{array}{l}\text { Ventilation } \\
\text { requirements }\end{array}$ & Standard 62.1-2004 & $\begin{array}{l}\text { Same as taxpayer's } \\
\text { buildinga }\end{array}$ \\
\hline Receptacle loads & $\begin{array}{l}\text { Taxpayer's building or the California Nonresidential } \\
\text { ACM }^{\mathrm{b}} \text { Approval Manual Tables N2-2 and N2-3 }\end{array}$ & $\begin{array}{l}\text { Same as reference } \\
\text { building model }\end{array}$ \\
\hline Process loads & $\begin{array}{l}\text { Taxpayer's building or the California Nonresidential ACM } \\
\text { Approval Manual } \S 2.4 .1 .5\end{array}$ & $\begin{array}{l}\text { Same as reference } \\
\text { building model }\end{array}$ \\
\hline Exterior lighting & Exclude from the simulations & $\begin{array}{l}\text { Exclude from the } \\
\text { simulations }\end{array}$ \\
\hline Schedules & $\begin{array}{l}\text { Taxpayer's building or the California Nonresidential ACM } \\
\text { Approval Manual Tables N2-2 and N2-3 }\end{array}$ & $\begin{array}{l}\text { Same as reference } \\
\text { building model }\end{array}$ \\
\hline Infiltration & $\begin{array}{l}\text { California Nonresidential ACM Approval Manual } \\
\S 2.4 .1 .6 \text { (See Appendix B) }\end{array}$ & $\begin{array}{l}\text { Same as taxpayer's } \\
\text { buildinga }^{\text {a }}\end{array}$ \\
\hline
\end{tabular}

a For a partially qualifying property, the nonqualifying systems in the proposed building model must match the corresponding systems in the reference building model.

${ }^{\mathrm{b}} \mathrm{ACM}=$ alternative calculation method 


\subsection{Internal Loads and Schedules}

The internal loads and operating schedules used in the energy simulations shall be the same for the reference building and the proposed building models. Use the internal loads and schedules from the taxpayer's building if they are known or from the California Nonresidential ACM Approval Manual listed in Table 4 and included in Appendix C of this document. The schedules include schedules for occupancy, heating, cooling, fans, lights, equipment, infiltration, and hot water. Document the schedules used in the simulations.

Table 5. Internal Loads and Schedules (Included as Appendix C)

\begin{tabular}{|l|l|}
\hline Load/Schedule & Source \\
\hline \hline Occupancy rates & California Nonresidential ACM Approval Manual Tables N2-2 and N2-3 \\
\hline Occupant loads & California Nonresidential ACM Approval Manual Tables N2-2 and N2-3 \\
\hline Hot water loads & California Nonresidential ACM Approval Manual Tables N2-2 and N2-3 \\
\hline Receptacle loads & California Nonresidential ACM Approval Manual Tables N2-2 and N2-3 \\
\hline Process loads & California Nonresidential ACM Approval Manual Section 2.4.1.5 \\
\hline Occupancy schedules & California Nonresidential ACM Approval Manual Tables N2-4 to N2-9 \\
\hline
\end{tabular}

\subsection{Use of Standard 90.1-2007 Appendix G}

The Performance Rating Method in Appendix G of Standard 90.1-2007 provides an approach for rating the performance of building designs that exceed the requirements of the standard. IRS Notice 2006-52 (IRS 2006) states that this method shall be used to estimate the energy and power cost savings of the taxpayer's building. However, differences do exist between the Performance Rating Method as stated in Standard 90.1-2007 Appendix G and the requirements for the tax deduction. Table 5 lists these differences. 
Table 6. Differences between the Performance Rating Method from Appendix $\mathbf{G}$ of Standard 90.1-2007 and the Requirements for the 179D Tax Deduction

\begin{tabular}{|c|c|}
\hline Section of Appendix G & Requirement for Tax Deduction \\
\hline G1.2 Performance Rating & $\begin{array}{l}\text { The reference building model shall meet the mandatory provisions of } \\
\S 5.4,6.4,7.4 \text {, and } 9.4 \text { in Standard } 90.1-2007 \text {. The proposed building } \\
\text { model shall meet the same mandatory provisions, except for the systems } \\
\text { applying for the tax deductions, which shall match the taxpayer's building. }\end{array}$ \\
\hline G1.2 Performance Rating & $\begin{array}{l}\text { Energy performance savings include only the energy and power costs } \\
\text { from the interior lighting, HVAC, and SHW systems (see Section } 3.1 \text { of } \\
\text { this document). }\end{array}$ \\
\hline $\begin{array}{l}\text { G1.4 Documentation } \\
\text { Requirements }\end{array}$ & $\begin{array}{l}\text { The documentation requirements for the tax deductions are defined in } \\
\text { IRS Notice 2006-52a Section } 4 .\end{array}$ \\
\hline G2.2 Simulation Program & $\begin{array}{l}\text { The simulation program must be on DOE's list of qualified software } \\
\text { (see Section } 3.2 \text { of this document). }\end{array}$ \\
\hline G2.3 Climate Data & The design day data are defined in Section 3.3 of this document. \\
\hline G2.4 Energy Rates & $\begin{array}{l}\text { On-site renewable electricity production shall not be included in the } \\
\text { reference building or in the proposed building models. Site-recovered } \\
\text { energy is allowed in the models. }\end{array}$ \\
\hline $\begin{array}{l}\text { G2.5 Exceptional } \\
\text { Calculation Methods }\end{array}$ & $\begin{array}{l}\text { Exceptional calculation methods are not allowed per IRS Notice 2006-52 } \\
6.01(5)(\mathrm{b})(\mathrm{ii}) .^{\text {a }}\end{array}$ \\
\hline Table G3.1(4) Schedules & $\begin{array}{l}\text { Use California Nonresidential ACM Approval Manual or the taxpayer's } \\
\text { building if they are known (see Section } 3.6 \text { of this document). }\end{array}$ \\
\hline Table G3.1(6) Lighting & $\begin{array}{l}\text { For a fully qualifying property or a partially qualifying lighting property, the } \\
\text { proposed building model shall match the taxpayer's building with the } \\
\text { following changes: } \\
\text { (1) For lighting systems that have been designed, the lighting power shall } \\
\text { be determined using luminaire power values from the California } \\
\text { Nonresidential ACM Approval Manual Appendix NB (CEC } 2004 \text { and } \\
\text { Appendix D of this document) or manufacturer's data. } \\
\text { (2) Credit may be taken for the use of automatic controls for daylight } \\
\text { utilization only if their operation is modeled in the energy simulation } \\
\text { software. }\end{array}$ \\
\hline $\begin{array}{l}\text { Table G3.1(10) HVAC } \\
\text { Systems }\end{array}$ & $\begin{array}{l}\text { For a fully qualifying property or a partially qualifying HVAC and SHW } \\
\text { property, the proposed building model may use the standard rating } \\
\text { conditions in } \S 6.4 .1 .1 \text { in Standard } 90.1-2007 \text {. }\end{array}$ \\
\hline $\begin{array}{l}\text { Table G3.1(12) } \\
\text { Receptacle and Other } \\
\text { Loads }\end{array}$ & $\begin{array}{l}\text { The receptacle and other loads for both building models shall be identical } \\
\text { (see Section } 3.5 \text { of this document). }\end{array}$ \\
\hline $\begin{array}{l}\text { Table G3.1(13) Modeling } \\
\text { Limitations to the } \\
\text { Simulation Program }\end{array}$ & $\begin{array}{l}\text { The simulation program must contain calculation methodologies for } \\
\text { the building components being modeled per IRS Notice } 2006-52 \\
6.01(5)(\mathrm{b})(\mathrm{ii})^{\mathrm{a}}\end{array}$ \\
\hline
\end{tabular}

a IRS 2006 


\subsection{Model Documentation}

The reference building and the proposed building models shall be documented to show that:

1. The reference building model meets the minimum requirements of Standard 90.1-2007.

2. The proposed building model matches the reference building model except for the systems qualifying for the tax deduction, which must match the taxpayer's building.

The models can be documented by (1) using reports generated by the modeling software, (2) manually completing the compliance forms from the Standard 90.1-2007 User's Manual, or (3) using equivalent forms. The list of approved software is available from DOE (n.d.). The Standard 90.1-2007 User's Manual compliance forms can be downloaded from ASHRAE Standards Forms website (ASHRAE 2016). Specific guidance for each system is provided in Sections 3.7.1 through 3.7.3.

\subsubsection{Building Envelope}

Document that the reference building model meets the Standard 90.1-2007 envelope performance requirements. For a partially qualifying lighting or HVAC and SHW property, document that the proposed building model matches the reference building model. For a fully qualifying property or a partially qualifying envelope property, document that the proposed building model matches the taxpayer's building, which must also meet the mandatory requirements according to the requirements of Section 4.2 of Standard 90.1-2007.

\subsubsection{Interior Lighting}

1. Document that the lighting power for the reference building model meets the allowable lighting power per Standard 90.1-2007.

2. Document that the lighting power for the proposed building model matches the reference building model for partially qualifying envelope or HVAC and SHW properties. Or, document that the lighting power for the proposed building model matches the taxpayer's building for partially qualifying lighting or fully qualifying properties.

3. Document the lighting controls specified for the proposed building model in Table A-2 in Appendix A or with copies of the building plans and specifications. Include a short description of the controls and set points for each lighting system.

\subsubsection{HVAC and SHW Systems}

1. Document that the HVAC and SHW systems for the reference building model meets the minimum requirements of Standard 90.1-2007.

2. Document that the HVAC and SHW system for the proposed building model matches the reference building model for partially qualifying envelope or lighting properties. Or, document that the HVAC and SHW system for the proposed building model matches the taxpayer's building for partially qualifying HVAC and SHW or fully qualifying properties, which must also meet the mandatory requirements according to the requirements of Section 4.2 of Standard 90.1-2007. 
3. Document systems in the proposed building model that are not covered in the Standard 90.1-2007 mandatory provisions. Include fans and pumps with capacity greater than or equal to 5 horsepower (hp), economizer operation, thermal energy storage systems, energy recovery systems, natural ventilation, demand controlled ventilation, desiccant systems, combined heat and power systems, and other energy systems associated with the HVAC and SHW systems. Also include in the documentation the equipment type, manufacturer model (if available), size, operating conditions, efficiencies, and control sequences. This information can be documented by including copies of the appropriate pages from the building plans and specifications. 


\section{Inspection Guidelines}

This section provides guidelines for inspecting the systems in the taxpayer's building. The inspection must be completed by a qualified individual ${ }^{3}$ as defined in IRS Notice 2006-52 (IRS 2006) after the building has been placed in service. Only the systems being used for the tax deductions need to be inspected. There are two objectives for the inspection:

- Verify that the taxpayer's building meets the necessary mandatory provisions of Standard 90.1-2007.

- Verify that the specifications of the energy systems installed in the taxpayer's building used for the tax deductions meet or exceed the performance specifications of the energy systems used in the proposed building model.

The qualified individual shall use the Standard 90.1-2007 compliance forms from the Standard 90.1-2007 User's Manual or equivalent forms to document that the necessary mandatory provisions required by Section 4.2 of Standard 90.1-2007 have been met in the taxpayer's building. Make necessary adjustments to the forms allowed by Section 4.2 of Standard 90.1-2007 for additions or alterations to existing buildings. These forms can be downloaded from ASHRAE Standards Forms website (ASHRAE 2016). The results of the inspection shall be compared with the proposed building model documentation to ensure the systems used for tax deductions in the taxpayer's building meet or exceed the proposed building model performance specifications. Specific guidance for each system is provided in Sections 4.1 through 4.3.

\subsection{Building Envelope}

For partially qualifying envelope or fully qualifying properties, complete the Standard 90.1-2007 building envelope compliance form or equivalent form to ensure the taxpayer's building meets or exceeds the Standard 90.1-2007 mandatory provisions according to the requirements in Section 4.2 in Standard 90.1-2007 and meets or exceeds the performance of the proposed building model.

\subsection{Interior Lighting}

For partially qualifying lighting or fully qualifying properties:

1. Complete the mandatory provision checklist on the Standard 90.1-2007 lighting compliance form or an equivalent form to ensure the taxpayer's building meets or exceeds the Standard 90.1-2007 mandatory provisions according to the requirements in Section 4.2 in Standard 90.1-2007.

2. Complete all the connected lighting power tables on the Standard 90.1-2007 lighting compliance form or equivalent form and ensure the total lighting power is less than or equal to the lighting power in the proposed building model.

3. Record the IESNA-recommended minimum and the measured illuminance for each space in Table A-1 (Appendix A) or an equivalent table for the taxpayer's building. Record the average of measurements taken on the working surfaces or at the locations listed by the

\footnotetext{
${ }^{3}$ A qualified individual is defined as a licensed contractor or engineer in the jurisdiction where the building is located.
} 
IESNA handbook (IESNA 2011). The average shall equal or exceed the IESNArecommended minimum illuminance levels. In addition, no more than $2.5 \%$ of the measurements may be below one-third of the IESNA-recommended minimum illuminance levels; the latter requirement assumes a normal distribution of data points, with two standard deviations from the measurements equal to one-third of the recommended illuminance level. Measurements need to be completed only once for each unique space and lighting arrangement.

4. Verify that the lighting controls match the performance of the controls specified in the proposed building energy model in Table A-2 (Appendix A) or equivalent documentation. If the controls in the taxpayer's building are different from those in the proposed building model, the proposed building model should be changed to match the taxpayer's building and resimulated to ensure the correct energy and power cost savings are achieved.

\subsection{HVAC and SHW Systems}

For partially qualifying HVAC and SHW or fully qualifying properties:

1. Compete the Standard 90.1-2007 compliance form for HVAC and SHW systems or an equivalent form to ensure the taxpayer's building design meets or exceeds the Standard 90.1-2007 mandatory provisions and the proposed building model according to the requirements in Section 4.2 in Standard 90.1-2007.

2. Verify against the documentation completed during the energy modeling of other systems not covered in the Standard 90.1-2007 mandatory provisions. This verification includes fans and pumps greater than or equal to $5 \mathrm{hp}$, economizer operation, thermal energy storage systems, energy recovery systems, natural ventilation, demand controlled ventilation, desiccant systems, combined heat and power systems, and other energy systems. Include in the inspection the equipment type, manufacturer model (if available), size, operating conditions, efficiencies, and control sequences.

3. Verify that the HVAC and SHW controls match the performance specifications of the controls specified in the proposed building energy model. If the systems in the taxpayer's building are less efficient than they are in the proposed building model, the proposed building model should be changed to match the taxpayer's building and resimulated to ensure the correct energy and power cost savings are achieved. 


\section{References}

ASHRAE. 2001. ASHRAE Handbook of Fundamentals. Atlanta, GA: American Society of Heating, Refrigerating and Air-Conditioning Engineers, Inc.

- 2007. ANSI/ASHRAE/IESNA Standard 90.1-2007 Energy Standard for Buildings Except Low-Rise Residential Buildings. Atlanta, GA: American Society of Heating, Refrigerating and Air-Conditioning Engineers, Inc.

- 2013a. ASHRAE Standard 169-2013 Weather Data for Building Design Standards. Atlanta, GA: American Society of Heating, Refrigerating and Air-Conditioning Engineers, Inc.

- 2013b. ASHRAE Handbook of Fundamentals. Atlanta, GA: American Society of Heating, Refrigerating and Air-Conditioning Engineers, Inc.

- 2016. ASHRAE Standards Forms and Procedures. Atlanta, GA: American Society of Heating, Refrigerating and Air-Conditioning Engineers, Inc. https://www.ashrae.org/standardsresearch--technology/standards-forms--procedures.

CEC. 2004. Nonresidential Alternative Calculation Method (ACM) Approval Manual for the 2005 Building Energy Efficiency Standards for Residential and Nonresidential Buildings. P40003-004F. Sacramento, CA: California Energy Commission.

http://www.energy.ca.gov/title24/2005standards/nonresidential_acm/2005_NONRES_ACM_M ANUAL.PDF.

CEC. 2006. 2005 Building Energy Efficiency Standards for Residential and Nonresidential Buildings. CEC-400-2006-015. Sacramento, CA: California Energy Commission. http://www.energy.ca.gov/title24/2005standards/.

Deru, M. 2007. Energy Savings Modeling and Inspection Guidelines for Commercial Building Federal Tax Deductions: Second Edition. Golden, CO: National Renewable Energy Laboratory. NREL/TP-550-40467. http://www.nrel.gov/docs/fy07osti/40467.pdf.

DOE (U.S. Department of Energy). n.d. Qualified Software for Calculating Commercial Building Tax Deductions. http://energy.gov/eere/buildings/qualified-software-calculatingcommercial-building-tax-deductions.

EIA (U.S. Energy Information Administration). 2016. Average Retail Price of Electricity. Washington, DC: U.S. Energy Information Administration. http://www.eia.doe.gov/

EnergyPlus. n.d. Weather Data. https://energyplus.net/weather.

IESNA (Illuminating Engineering Society of North America). 2011. The Lighting Handbook Tenth Edition. New York, NY: Illuminating Engineering Society of North America.

IRS (Internal Revenue Service). 2006. Notice 2006-52. Washington, DC: Internal Revenue Service. https://www.irs.gov/pub/irs-drop/n-06-52.pdf. 
. 2008. Notice 2008-40. Washington, DC: Internal Revenue Service. https://www.irs.gov/irb/2008-14_IRB/ar12.html.

2012. Notice 2012-26. Washington, DC: Internal Revenue Service. https://www.irs.gov/pub/irs-irbs/irb12-17.pdf. 


\section{Appendix A. Lighting System Compliance Form}

Appendix A provides example tables that can be used to document the lighting systems and controls for lighting systems. These tables do not need to be used, but the information contained in these tables must be documented in some form for the lighting portion of the 179D tax deduction.

\begin{tabular}{|l|l|}
\hline Project Name: & Date: \\
\hline Project Address: & \\
\hline $\begin{array}{l}\text { Building Owner (name and address of all taxpayers claiming a tax } \\
\text { deduction): }\end{array}$ & Telephone: \\
\hline Energy Modeler (name and address): & \\
\hline Energy Inspector (name and address): & Telephone: \\
\hline
\end{tabular}

Telephone:

Tables A-1 through A-4 are Tables LF1 through LF4 from Deru (2007). 
Table A-1. Illuminance Levels (Table LF1 from Deru 2007)

\begin{tabular}{|l|l|l|}
\hline Building/Space & $\begin{array}{c}\text { IESNA 2000 } \\
\text { Minimum } \\
\text { (lux) }\end{array}$ & $\begin{array}{c}\text { Taxpayer's } \\
\text { Building } \\
\text { Measured } \\
\text { (lux) }\end{array}$ \\
\hline \hline & & \\
\hline & & \\
\hline & & \\
\hline & & \\
\hline & & \\
\hline
\end{tabular}

Table A-2. Lighting Controls Description in the Proposed Building Energy Model (Table LF2 from Deru 2007)

\begin{tabular}{|l|l|}
\hline Building/Space & $\begin{array}{c}\text { Proposed Building Model } \\
\text { Control System and Set Points }\end{array}$ \\
\hline \hline & \\
\hline & \\
\hline & \\
\hline & \\
\hline & \\
\hline & \\
\hline
\end{tabular}

Table A-3. Lighting Controls Description in the Taxpayer's Building (Table LF3 from Deru 2007)

\begin{tabular}{|l|l|}
\hline Building/Space & $\begin{array}{c}\text { Taxpayer's Building } \\
\text { Control System and Set Points }\end{array}$ \\
\hline \hline & \\
\hline & \\
\hline & \\
\hline & \\
\hline & \\
\hline & \\
\hline
\end{tabular}

Table A-4. Additional Lighting Systems Mandatory Provisions Checklist for the Interim Lighting Rule (Table LF4 from Deru 2007)

\begin{tabular}{|l|c|}
\hline \multicolumn{1}{|c|}{ Provision } & $\begin{array}{c}\text { Taxpayer's } \\
\text { Building }\end{array}$ \\
\hline \hline Include provision for bi-level switching in all occupancies & \\
\hline Exception: hotel and motel guest rooms, store rooms, restrooms, and public lobbies & \\
\hline
\end{tabular}




\section{Appendix B. Infiltration Modeling Rules}

Table B-1 lists the modeling rules from the 2005 California Nonresidential ACM Approval Manual for including infiltration in both the reference building model and the proposed building model unless there is an envelope measure that reduces infiltration in the taxpayer's building and the project team is applying for the whole building or envelope tax deduction (CEC 2004).

Table B-1. Insert Table Caption Here

\begin{tabular}{|c|c|}
\hline Design Type & Modeling Rules \\
\hline \multirow[t]{4}{*}{ Proposed Design } & $\begin{array}{l}\text { Infiltration shall be modeled as either "ON" or "OFF" for each zone, } \\
\text { according to the following: }\end{array}$ \\
\hline & $\begin{array}{l}\text { "OFF" if fans are ON and zone supply air quantity (including transfer air) is } \\
\text { greater than zone exhaust air quantity. }\end{array}$ \\
\hline & "ON" if fans are OFF. \\
\hline & $\begin{array}{l}\text { When infiltration is "ON," the reference method calculates the infiltration } \\
\text { rate as } 0.038 \text { cubic feet per minute (CFM) per square foot of gross exterior } \\
\text { partition (walls and windows) area for the zone. }\end{array}$ \\
\hline Standard Design (All) & $\begin{array}{l}\text { ACMs shall model infiltration for the standard design exactly the same as } \\
\text { the proposed design. }\end{array}$ \\
\hline
\end{tabular}




\section{Appendix C. Internal Loads and Schedules}

Tables C-1 through C-8 are Tables N2-2 through Table N2-9 from the 2005 California Nonresidential ACM Approval Manual (CEC 2004).

Table C-1. Occupancy Assumptions When Lighting Plans are Submitted for the Entire Building or When Lighting Compliance Is Not Performed (Table N2-2 from CEC 2004)

\begin{tabular}{|c|c|c|c|c|c|c|c|}
\hline Occupancy Type & $\begin{array}{l}\text { People per } \\
1,000 \mathrm{ft}^{\mathrm{a}}\end{array}$ & $\begin{array}{l}\text { Sensible Heat } \\
\text { per Person }^{b}\end{array}$ & \begin{tabular}{|l|} 
Latent Heat \\
per Person
\end{tabular} & $\begin{array}{l}\text { Receptacle } \\
\text { Load }\left(\mathbf{W} / \mathrm{ft}^{2}\right)^{\mathrm{c}}\end{array}$ & $\begin{array}{l}\text { Hot Water } \\
\text { (Btu/h per } \\
\text { Person) }\end{array}$ & $\begin{array}{l}\text { Lighting } \\
(\text { W/ftt })^{d}\end{array}$ & $\begin{array}{l}\text { Ventilation } \\
(\text { CFM/ft' })^{\mathrm{e}}\end{array}$ \\
\hline Auditoriums ${ }^{h}$ & 143 & 245 & 105 & 1.0 & 60 & 1.5 & 1.07 \\
\hline Convention Centers ${ }^{\mathrm{h}}$ & 136 & 245 & 112 & 0.96 & 57 & 1.3 & 1.02 \\
\hline Financial Institutions & 10 & 250 & 250 & 1.5 & 120 & 1.1 & 0.15 \\
\hline $\begin{array}{l}\text { General Commercial } \\
\text { and Industrial Work } \\
\text { Buildings, High Bay }\end{array}$ & 7 & 375 & 625 & 1.0 & 120 & 1.1 & 0.15 \\
\hline $\begin{array}{l}\text { General Commercial } \\
\text { and Industrial Work } \\
\text { Buildings, Low Bay }\end{array}$ & 7 & 375 & 625 & 1.0 & 120 & 1.0 & 0.15 \\
\hline Grocery Stores $^{h}$ & 29 & 252 & 225 & 0.91 & 113 & 1.5 & 0.22 \\
\hline Hotels $^{f}$ & 20 & 250 & 200 & 0.5 & 60 & 1.4 & 0.15 \\
\hline $\begin{array}{l}\text { Industrial and } \\
\text { Commercial Storage } \\
\text { Buildings }\end{array}$ & 5 & 268 & 403 & 0.43 & 108 & 0.7 & 0.15 \\
\hline $\begin{array}{l}\text { Medical Buildings } \\
\text { and Clinics }\end{array}$ & 10 & 250 & 213 & 1.18 & 110 & 1.1 & 0.15 \\
\hline Office Buildings & 10 & 250 & 206 & 1.34 & 106 & 1.1 & 0.15 \\
\hline Religious Facilities $^{\text {h }}$ & 136 & 245 & 112 & 0.96 & 57 & 1.6 & 1.03 \\
\hline Restaurants $^{\mathrm{h}}$ & 45 & 274 & 334 & 0.79 & 366 & 1.2 & 0.38 \\
\hline $\begin{array}{l}\text { Retail and Wholesale } \\
\text { Stores }^{g}\end{array}$ & 29 & 252 & 224 & 0.94 & 116 & 1.5 & 0.22 \\
\hline
\end{tabular}




\begin{tabular}{|c|c|c|c|c|c|c|c|}
\hline Occupancy Type & $\begin{array}{l}\text { People per } \\
1,000 \mathrm{ft}^{\mathrm{a}}\end{array}$ & $\begin{array}{l}\text { Sensible Heat } \\
\text { per Person }^{\text {b }}\end{array}$ & $\begin{array}{l}\text { Latent Heat } \\
\text { per Person }\end{array}$ & \begin{tabular}{|l|} 
Receptacle \\
Load $\left(\mathrm{W} / \mathrm{ft}^{2}\right)^{\mathrm{c}}$
\end{tabular} & $\begin{array}{l}\text { Hot Water } \\
\text { (Btu/h per } \\
\text { Person) }\end{array}$ & $\begin{array}{l}\text { Lighting } \\
\left.(\text { W/ft })^{2}\right)^{d}\end{array}$ & $\begin{array}{l}\text { Ventilation } \\
\left(\text { CFM/ft }{ }^{2}\right)^{\mathrm{e}}\end{array}$ \\
\hline Schools ${ }^{h}$ & 40 & 246 & 171 & 1.0 & 108 & 1.2 & 0.32 \\
\hline Theaters $^{h}$ & 130 & 268 & 403 & 0.54 & 60 & 1.3 & 0.98 \\
\hline All Others & 10 & 250 & 200 & 1.0 & 120 & 0.6 & 0.15 \\
\hline
\end{tabular}

a Most occupancy values are based on an assumed mix of sub-occupancies within the area. These values were based on one-half the maximum occupant load for exiting purposes in the California Building Code (CBC). Use full values for design conditions. Full year operational schedules reduce these values by up to $50 \%$ for compliance simulations and full-year test simulations.

b From Table 1, p. 29.4, ASHRAE 2001Handbook of Fundamentals (ASHRAE 2001)

c From Lawrence Berkeley Laboratory study; this value is fixed and includes all equipment plugged into receptacle outlets.

${ }^{d}$ From Table 146-B of the California 2005 Building Energy Efficiency Standards for the applicable occupancy; the LPD of the standard building for areas where no lighting plans or specifications are submitted for permit and the occupancy of the building is not known is $1.2 \mathrm{~W} / \mathrm{ft}^{2}$ (CEC 2006)

e Developed from Section 121 and Table 121-A of the California 2005 Building Energy Efficiency Standards (CEC 2006).

f Hotel uses values for Hotel Function Area from Table N2-3.

${ }^{g}$ For retail and wholesale stores, the complete building method may only be used when the sales area is $70 \%$ or greater of the building area.

${ }^{\mathrm{h}}$ For these occupancies, when the proposed design is required to have demand control ventilation by Section 121 (c) 3 , the ventilation rate is the minimum that would occur at any time during occupied hours. Additional ventilation would be provided through demand-controlled ventilation to maintain carbon dioxide $\left(\mathrm{CO}_{2}\right)$ levels according to Section 121 of the California 2005 Building Energy Efficiency Standards (CEC 2006). 
Table C-2. Area Occupancy Assumptions When Lighting Plans are Submitted for Portions or for the Entire Building or When Lighting Compliance is Not Performed (Table N2-3 from CEC 2004)

\begin{tabular}{|c|c|c|c|c|c|c|c|}
\hline $\begin{array}{l}\text { Sub-Occupancy } \\
\text { Type }^{\text {a }}\end{array}$ & $\begin{array}{l}\text { People } \\
\text { per } 1,000 \\
\mathrm{ft}^{\mathrm{b}}\end{array}$ & $\begin{array}{l}\text { Sensible } \\
\text { Heat per } \\
\text { Personc }\end{array}$ & $\begin{array}{l}\text { Latent } \\
\text { Heat per } \\
\text { Personc }\end{array}$ & $\begin{array}{l}\text { Receptacle } \\
\text { Load } \\
(W / f t 2)^{d}\end{array}$ & $\begin{array}{l}\text { Hot Water } \\
\text { (Btu/h per } \\
\text { Person) }\end{array}$ & $\begin{array}{l}\text { Lighting } \\
(\mathrm{W} / \mathrm{ft} 25)^{\mathrm{e}}\end{array}$ & $\begin{array}{l}\text { Ventilation } \\
\text { (CFM/ft2) }^{f}\end{array}$ \\
\hline Auditorium ${ }^{g}$ & 143 & 245 & 105 & 1.0 & 60 & 1.5 & 1.07 \\
\hline Auto Repair & 10 & 275 & 475 & 1.0 & 120 & 1.1 & 1.50 \\
\hline $\begin{array}{l}\text { Bar, Cocktail Lounge } \\
\text { and Casinog }\end{array}$ & 67 & 275 & 275 & 1.0 & 120 & 1.1 & 0.50 \\
\hline $\begin{array}{l}\text { Barber and Beauty } \\
\text { Shop }\end{array}$ & 10 & 250 & 200 & 2.0 & 120 & 1.0 & 0.40 \\
\hline $\begin{array}{l}\text { Classrooms, Lecture, } \\
\text { Training, Vocational } \\
\text { Room }\end{array}$ & 50 & 245 & 155 & 1.0 & 120 & 1.2 & 0.38 \\
\hline Civic Meeting Spaceg & 25 & 250 & 200 & 1.5 & 120 & 1.3 & 0.19 \\
\hline $\begin{array}{l}\text { Commercial and } \\
\text { Industrial Storage }\end{array}$ & 3 & 275 & 475 & 0.2 & 120 & 0.6 & 0.15 \\
\hline $\begin{array}{l}\text { Convention, } \\
\text { Conference, Multi- } \\
\text { purpose and } \\
\text { Meeting Centers }\end{array}$ & 67 & 245 & 155 & 1.0 & 60 & 1.4 & 0.50 \\
\hline $\begin{array}{l}\text { Corridors, Restrooms, } \\
\text { Stairs, and Support } \\
\text { Areas }\end{array}$ & 10 & 250 & 250 & 0.2 & 0 & 0.6 & 0.15 \\
\hline Dining $^{9}$ & 67 & 275 & 275 & 0.5 & 385 & 1.1 & 0.50 \\
\hline $\begin{array}{l}\text { Electrical, Mechanical } \\
\text { Room }\end{array}$ & 3 & 250 & 250 & 0.2 & 0 & 0.7 & 0.15 \\
\hline $\begin{array}{l}\text { Exercise, Center, } \\
\text { Gymnasium }\end{array}$ & 20 & 255 & 875 & 0.5 & 120 & 1.0 & 0.15 \\
\hline Exhibit, Museum ${ }^{g}$ & 67 & 250 & 250 & 1.5 & 60 & 2.0 & 0.50 \\
\hline
\end{tabular}




\begin{tabular}{|c|c|c|c|c|c|c|c|}
\hline $\begin{array}{l}\text { Sub-Occupancy } \\
\text { Type }^{\text {a }}\end{array}$ & $\begin{array}{l}\text { People } \\
\text { per } 1,000 \\
\mathrm{ft}^{\mathrm{b}}\end{array}$ & $\begin{array}{l}\text { Sensible } \\
\text { Heat per } \\
\text { Personc }\end{array}$ & $\begin{array}{l}\text { Latent } \\
\text { Heat per } \\
\text { Personc }\end{array}$ & $\begin{array}{l}\text { Receptacle } \\
\text { Load } \\
(\mathrm{W} / \mathrm{ft} 2)^{\mathrm{d}}\end{array}$ & $\begin{array}{l}\text { Hot Water } \\
\text { (Btu/h per } \\
\text { Person) }\end{array}$ & $\begin{array}{l}\text { Lighting } \\
(\mathrm{W} / \mathrm{ft} 25)^{\mathrm{e}}\end{array}$ & $\begin{array}{l}\text { Ventilation } \\
\text { (CFM/ft2) }^{f}\end{array}$ \\
\hline Financial Transaction & 10 & 250 & 250 & 1.5 & 120 & 1.2 & 0.15 \\
\hline $\begin{array}{l}\text { Dry Cleaning (Coin } \\
\text { Operated) }\end{array}$ & 10 & 250 & 250 & 3.0 & 120 & 0.9 & 0.30 \\
\hline $\begin{array}{l}\text { Dry Cleaning (Full } \\
\text { Service Commercial) }\end{array}$ & 10 & 250 & 250 & 3.0 & 120 & 0.9 & 0.45 \\
\hline $\begin{array}{l}\text { General Commercial } \\
\text { and Industrial Work, } \\
\text { High Bay }\end{array}$ & 10 & 275 & 475 & 1.0 & 120 & 1.1 & 0.15 \\
\hline $\begin{array}{l}\text { General Commercial } \\
\text { and Industrial Work, } \\
\text { Low Bay }\end{array}$ & 10 & 275 & 475 & 1.0 & 120 & 1.0 & 0.15 \\
\hline $\begin{array}{l}\text { General Commercial } \\
\text { and Industrial Work, } \\
\text { Precision }\end{array}$ & 10 & 250 & 200 & 1.0 & 120 & 1. 3 & 0.15 \\
\hline Grocery Salesg & 33 & 250 & 200 & 1.0 & 120 & 1.6 & 0.25 \\
\hline $\begin{array}{l}\text { High-Rise Residential } \\
\text { Living Spaces }^{\mathrm{h}}\end{array}$ & 5 & 245 & 155 & 0.5 & $一^{i}$ & 0.5 & 0.15 \\
\hline Hotel Function Areag & 67 & 250 & 200 & 0.5 & 60 & 1.5 & 0.50 \\
\hline $\begin{array}{l}\text { Hotel/Motel Guest } \\
\text { Room }^{\mathrm{h}}\end{array}$ & 5 & 245 & 155 & 0.5 & 2800 & 0.5 & 0.15 \\
\hline $\begin{array}{l}\text { Housing, Public and } \\
\text { Common Areas, Multi- } \\
\text { family }\end{array}$ & 10 & 250 & 250 & 0.5 & 120 & 1.0 & 0.15 \\
\hline $\begin{array}{l}\text { Housing, Public and } \\
\text { Common Areas, } \\
\text { Dormitory, } \\
\text { Senior Housing }\end{array}$ & 10 & 250 & 250 & 0.5 & 120 & 1.5 & 0.15 \\
\hline Kitchen, Food & 5 & 275 & 475 & 1.5 & 385 & 1.6 & 0.15 \\
\hline
\end{tabular}




\begin{tabular}{|c|c|c|c|c|c|c|c|}
\hline $\begin{array}{l}\text { Sub-Occupancy } \\
\text { Type }\end{array}$ & $\begin{array}{l}\text { People } \\
\text { per } 1,000 \\
f t 2^{\text {b }}\end{array}$ & $\begin{array}{l}\text { Sensible } \\
\text { Heat per } \\
\text { Personc }\end{array}$ & $\begin{array}{l}\text { Latent } \\
\text { Heat per } \\
\text { Personc }\end{array}$ & $\begin{array}{l}\text { Receptacle } \\
\text { Load } \\
(\mathrm{W} / \mathrm{ft} 2)^{\mathrm{d}}\end{array}$ & $\begin{array}{l}\text { Hot Water } \\
\text { (Btu/h per } \\
\text { Person) }\end{array}$ & $\begin{array}{l}\text { Lighting } \\
(\mathrm{W} / \mathrm{ft} 25)^{\mathrm{e}}\end{array}$ & $\begin{array}{l}\text { Ventilation } \\
(\text { CFM/ft2) }\end{array}$ \\
\hline \multicolumn{8}{|l|}{ Preparation } \\
\hline Laundry & 10 & 250 & 250 & 3.0 & 385 & 0.9 & 0.15 \\
\hline $\begin{array}{l}\text { Library, Reading } \\
\text { Areas }\end{array}$ & 20 & 250 & 200 & 1.5 & 120 & 1.2 & 0.15 \\
\hline Library, Stacks & 10 & 250 & 200 & 1.5 & 120 & 1.5 & 0.15 \\
\hline Lobby, Hotel & 10 & 250 & 250 & 0.5 & 120 & 1.1 & 0.15 \\
\hline Lobby, Main Entry & 10 & 250 & 250 & 0.5 & 60 & 1.5 & 0.15 \\
\hline $\begin{array}{l}\text { Locker/Dressing } \\
\text { Room }\end{array}$ & 20 & 255 & 475 & 0.5 & 385 & 0.8 & 0.15 \\
\hline Lounge, Recreationg & 67 & 275 & 275 & 1.0 & 60 & 1.1 & 0.50 \\
\hline Malls and Atriag & 33 & 250 & 250 & 0.5 & 120 & 1.2 & 0.25 \\
\hline $\begin{array}{l}\text { Medical and Clinical } \\
\text { Care }\end{array}$ & 10 & 250 & 200 & 1.5 & 160 & 1.2 & 0.15 \\
\hline Office & 10 & 250 & 200 & 1.5 & 120 & 1.2 & 0.15 \\
\hline $\begin{array}{l}\text { Police Station and } \\
\text { Fire Station }\end{array}$ & 10 & 250 & 200 & 1.5 & 120 & 0.9 & 0.15 \\
\hline Religious Worshipg & 143 & 245 & 105 & 0.5 & 60 & 1.5 & 1.07 \\
\hline $\begin{array}{l}\text { Retail Merchandise } \\
\text { Sales, Wholesale } \\
\text { Showroom }\end{array}$ & 33 & 250 & 200 & 1.0 & 120 & 1.7 & 0.25 \\
\hline Tenant Lease Space & 10 & 250 & 200 & 1.5 & 120 & 1.0 & 0.15 \\
\hline $\begin{array}{l}\text { Theater, Motion } \\
\text { Picture }^{g}\end{array}$ & 143 & 245 & 105 & 0.5 & 60 & 0.9 & 1.07 \\
\hline $\begin{array}{l}\text { Theater, } \\
\text { Performanceg }\end{array}$ & 143 & 245 & 105 & 0.5 & 60 & 1.4 & 1.07 \\
\hline
\end{tabular}




\begin{tabular}{|c|c|c|c|c|c|c|c|}
\hline $\begin{array}{l}\text { Sub-Occupancy } \\
\text { Type }^{\text {a }}\end{array}$ & $\begin{array}{l}\text { People } \\
\text { per 1,000 } \\
\mathrm{ft2}{ }^{\mathrm{b}}\end{array}$ & $\begin{array}{l}\text { Sensible } \\
\text { Heat per } \\
\text { Personc }\end{array}$ & $\begin{array}{l}\text { Latent } \\
\text { Heat per } \\
\text { Personc }\end{array}$ & $\begin{array}{l}\text { Receptacle } \\
\text { Load } \\
(\mathrm{W} / \mathrm{ft} 2)^{\mathrm{d}}\end{array}$ & $\begin{array}{l}\text { Hot Water } \\
\text { (Btu/h per } \\
\text { Person) }\end{array}$ & $\begin{array}{l}\text { Lighting } \\
(\mathrm{W} / \mathrm{ft} 25)^{\mathrm{e}}\end{array}$ & $\begin{array}{l}\text { Ventilation } \\
\text { (CFM/ft2) }^{\mathrm{f}}\end{array}$ \\
\hline $\begin{array}{l}\text { Transportation } \\
\text { Functiong }\end{array}$ & 33 & 250 & 250 & 0.5 & 120 & 1.2 & 0.25 \\
\hline Waiting Area & 10 & 250 & 250 & 0.5 & 120 & 1.1 & 0.15 \\
\hline All Other & 10 & 250 & 200 & 1.0 & 120 & 0.6 & 0.15 \\
\hline
\end{tabular}

a Subcategories of these suboccupancies are described in Section 2.4.1.1 (Occupancy Types) of CEC 2004.

${ }^{b}$ Values are based on one-half the maximum occupant load for exiting purposes in the CBC. Use full values for design conditions. Full-year operational schedules reduce these values by up to $50 \%$ for compliance simulations and full year test simulations.

c From Table 1, p. 29.4, ASHRAE 2001 Handbook of Fundamentals (ASHRAE 2001).

${ }^{d}$ From Lawrence Berkeley Laboratory study. This value is fixed and includes all equipment that is plugged into receptacle outlets.

e From Table 146-C of the California 2005 Building Energy Efficiency Standards for the applicable occupancy. ACMs shall use this value for the standard building design when lighting compliance is performed for the zone or area in question (CEC 2006).

f Developed from Section 121 and Table 121-A of the California 2005 Building Energy Efficiency Standards (CEC 2006).

g For these occupancies, when the proposed design is required to have demand control ventilation by Section 121 (c) 3 , the ventilation rate is the minimum that would occur at any time during occupied hours. Additional ventilation would be provided through demand-controlled ventilation to maintain $\mathrm{CO}_{2}$ levels according to Section 121 of the California 2005 Building Energy Efficiency Standards (CEC 2006).

${ }^{\mathrm{h}}$ For hotel/motel guest rooms and high-rise residential living spaces, all these values are fixed and are the same for both the proposed design and the standard design. ACMs shall ignore user inputs that modify these assumptions for these two occupancies. Spaces in high-rise residential buildings other than living spaces shall use the values for housing, public and common areas (either multi-family or senior housing). 
Table C-3. Schedule Types of Occupancies and Sub-Occupancies (Table N2-4 from CEC 2004)

\begin{tabular}{|c|c|}
\hline Occupancy or Sub-Occupancy Type & Schedule \\
\hline Atrium & Table 2-5 Nonresidential \\
\hline Auditorium & Table 2-5 Nonresidential \\
\hline Auto Repair & Table 2-5 Nonresidential \\
\hline Bar, Cocktail Lounge and Casino & Table 2-5 Nonresidential \\
\hline Barber and Beauty Shop & Table 2-5 Nonresidential \\
\hline Classrooms, Lecture, Training, Vocational Room & Table 2-5 Nonresidential \\
\hline Civic Meeting Space & Table 2-5 Nonresidential \\
\hline Commercial and Industrial Storage & Table 2-5 Nonresidential \\
\hline Convention, Conference, Multipurpose, and Meeting Centers & Table 2-5 Nonresidential \\
\hline Corridors, Restrooms, Stairs, and Support Areas & Table 2-5 Nonresidential \\
\hline Dining & Table 2-5 Nonresidential \\
\hline Electrical, Mechanical Room & Table 2-5 Nonresidential \\
\hline Exercise Center, Gymnasium & Table 2-5 Nonresidential \\
\hline Exhibit, Museum & Table 2-5 Nonresidential \\
\hline Financial Transaction & Table 2-5 Nonresidential \\
\hline Dry Cleaning (Coin Operated) & Table 2-5 Nonresidential \\
\hline Dry Cleaning (Full Service Commercial) & Table 2-5 Nonresidential \\
\hline General Commercial and Industrial Work, High Bay & Table 2-5 Nonresidential \\
\hline General Commercial and Industrial Work, Low Bay & Table 2-5 Nonresidential \\
\hline General Commercial and Industrial Work, Precision & Table 2-5 Nonresidential \\
\hline Grocery Sales & Table 2-5 Nonresidential \\
\hline High-rise Residential with Setback Thermostat & Table 2-7 Residential, with Setback \\
\hline High-rise Residential without Setback Thermostat & Table 2-8 Residential, without Setback \\
\hline Hotel Function Area & Table 2-6 Hotel Function \\
\hline Hotel/Motel Guest Room with Setback Thermostat & Table 2-7 Residential, with Setback \\
\hline Hotel/Motel Guest Room without Setback Thermostat & Table 2-8 Residential, without Setback \\
\hline
\end{tabular}




\begin{tabular}{|c|c|}
\hline Occupancy or Sub-Occupancy Type & Schedule \\
\hline Housing, Public and Commons Areas, Multi-family with Setback Thermostat & Table 2-7 Residential, with Setback \\
\hline Housing, Public and Commons Areas, Multi-family without Setback & Table 2-8 Residential, without Setback Thermostat \\
\hline Housing, Public and Common Areas, Dormitory, Senior Housing with Setback & Table 2-7 Residential, with Setback Thermostat \\
\hline Housing, Public and Commons Areas, Dormitory, Senior Housing without & Table 2-8 Residential, without Setback Thermostat \\
\hline Kitchen, Food Preparation & Table 2-5 Nonresidential \\
\hline Laundry & Table 2-5 Nonresidential \\
\hline Library, Reading Areas & Table 2-5 Nonresidential \\
\hline Library, Stacks & Table 2-5 Nonresidential \\
\hline Lobby, Hotel & Table 2-6 Hotel Function \\
\hline Lobby, Main Entry & Table 2-5 Nonresidential \\
\hline Locker/Dressing Room & Table 2-5 Nonresidential \\
\hline Lounge, Recreation & Table 2-5 Nonresidential \\
\hline Mall & Table 2-9 Retail \\
\hline Medical and Clinical Care & Table 2-5 Nonresidential \\
\hline Office & Table 2-5 Nonresidential \\
\hline Police Station and Fire Station & Table 2-5 Nonresidential \\
\hline Religious Worship & Table 2-5 Nonresidential \\
\hline Retail Merchandise Sales, Wholesale Showroom & Table 2-9 Retail \\
\hline Tenant Lease Space & Table 2-5 Nonresidential \\
\hline Theater, Motion Picture & Table 2-5 Nonresidential \\
\hline Theater, Performance & Table 2-5 Nonresidential \\
\hline Transportation Function & Table 2-5 Nonresidential \\
\hline Waiting Area & Table 2-5 Nonresidential \\
\hline All Other & Table 2-5 Nonresidential \\
\hline
\end{tabular}




\section{Table C-4 (CEC 2004, Table C-4. Nonresidential Occupancy Schedules (Other than Retail) (Table N2-5 from CEC 2004)}

\begin{tabular}{|c|c|c|c|c|c|c|c|c|c|c|c|c|c|c|c|c|c|c|c|c|c|c|c|c|c|}
\hline & & \multicolumn{24}{|c|}{ Hour } \\
\hline & & 1 & 2 & 3 & 4 & 5 & 6 & 7 & 8 & 9 & 10 & 11 & 12 & 13 & 14 & 15 & 16 & 17 & 18 & 19 & 20 & 21 & 22 & 23 & 24 \\
\hline Heating & WD & 60 & 60 & 60 & 60 & 60 & 65 & 65 & 70 & 70 & 70 & 70 & 70 & 70 & 70 & 70 & 70 & 70 & 70 & 65 & 60 & 60 & 60 & 60 & 60 \\
\hline \multirow[t]{2}{*}{$\left({ }^{\circ} \mathrm{F}\right)$} & Sat & 60 & 60 & 60 & 60 & 60 & 65 & 65 & 65 & 65 & 65 & 65 & 65 & 65 & 65 & 65 & 65 & 60 & 60 & 60 & 60 & 60 & 60 & 60 & 60 \\
\hline & Sun & 60 & 60 & 60 & 60 & 60 & 65 & 65 & 65 & 65 & 65 & 65 & 65 & 65 & 65 & 65 & 65 & 60 & 60 & 60 & 60 & 60 & 60 & 60 & 60 \\
\hline Cooling & WD & 77 & 77 & 77 & 77 & 77 & 73 & 73 & 73 & 73 & 73 & 73 & 73 & 73 & 73 & 73 & 73 & 73 & 73 & 77 & 77 & 77 & 77 & 77 & 77 \\
\hline \multirow[t]{2}{*}{$\left({ }^{\circ} \mathrm{F}\right)$} & Sat & 77 & 77 & 77 & 77 & 77 & 73 & 73 & 73 & 73 & 73 & 73 & 73 & 73 & 73 & 73 & 73 & 73 & 73 & 77 & 77 & 77 & 77 & 77 & 77 \\
\hline & Sun & 77 & 77 & 77 & 77 & 77 & 73 & 73 & 73 & 73 & 73 & 73 & 73 & 73 & 73 & 73 & 73 & 73 & 73 & 77 & 77 & 77 & 77 & 77 & 77 \\
\hline Lights & WD & 5 & 5 & 5 & 5 & 10 & 20 & 40 & 70 & 80 & 85 & 85 & 85 & 85 & 85 & 85 & 85 & 85 & 80 & 35 & 10 & 10 & 10 & 10 & 10 \\
\hline \multirow[t]{2}{*}{ (\%) } & Sat & 5 & 5 & 5 & 5 & 5 & 10 & 15 & 25 & 25 & 25 & 25 & 25 & 25 & 25 & 20 & 20 & 20 & 15 & 10 & 10 & 10 & 10 & 10 & 10 \\
\hline & Sun & 5 & 5 & 5 & 5 & 5 & 10 & 10 & 15 & 15 & 15 & 15 & 15 & 15 & 15 & 15 & 15 & 15 & 10 & 10 & 10 & 5 & 5 & 5 & 5 \\
\hline Equipment & WD & 15 & 15 & 15 & 15 & 15 & 20 & 35 & 60 & 70 & 70 & 70 & 70 & 70 & 70 & 70 & 70 & 65 & 45 & 30 & 20 & 20 & 15 & 15 & 15 \\
\hline \multirow[t]{2}{*}{ (\%) } & Sat & 15 & 15 & 15 & 15 & 15 & 15 & 15 & 20 & 25 & 25 & 25 & 25 & 25 & 25 & 20 & 20 & 20 & 15 & 15 & 15 & 15 & 15 & 15 & 15 \\
\hline & Sun & 15 & 15 & 15 & 15 & 15 & 15 & 15 & 20 & 20 & 20 & 20 & 20 & 20 & 20 & 20 & 20 & 20 & 15 & 15 & 15 & 15 & 15 & 15 & 15 \\
\hline \multirow[t]{3}{*}{ Fans } & WD & off & off & off & off & off & on & on & on & on & on & on & on & on & on & on & on & on & on & on & on & off & off & off & off \\
\hline & Sat & off & off & off & off & on & on & on & on & on & on & on & on & on & on & on & off & off & off & off & off & off & off & off & off \\
\hline & Sun & off & off & off & off & off & off & off & off & off & off & off & off & off & off & off & off & off & off & off & off & off & off & off & off \\
\hline Infiltration & WD & 100 & 100 & 100 & 100 & 100 & 0 & 0 & 0 & 0 & 0 & 0 & 0 & 0 & 0 & 0 & 0 & 0 & 0 & 0 & 0 & 100 & 100 & 100 & 100 \\
\hline \multirow[t]{2}{*}{ (\%) } & Sat & 100 & 100 & 100 & 100 & 100 & 0 & 0 & 0 & 0 & 0 & 0 & 0 & 0 & 0 & 0 & 100 & 100 & 100 & 100 & 100 & 100 & 100 & 100 & 100 \\
\hline & Sun & 100 & 100 & 100 & 100 & 100 & 100 & 100 & 100 & 100 & 100 & 100 & 100 & 100 & 100 & 100 & 100 & 100 & 100 & 100 & 100 & 100 & 100 & 100 & 100 \\
\hline People & WD & 0 & 0 & 0 & 0 & 5 & 10 & 25 & 65 & 65 & 65 & 65 & 60 & 60 & 65 & 65 & 65 & 65 & 40 & 25 & 10 & 5 & 5 & 5 & 0 \\
\hline \multirow[t]{2}{*}{ (\%) } & Sat & 0 & 0 & 0 & 0 & 0 & 0 & 5 & 15 & 15 & 15 & 15 & 15 & 15 & 15 & 15 & 15 & 15 & 5 & 5 & 5 & 0 & 0 & 0 & 0 \\
\hline & Sun & 0 & 0 & 0 & 0 & 0 & 0 & 0 & 5 & 5 & 5 & 5 & 5 & 5 & 5 & 5 & 5 & 5 & 5 & 5 & 5 & 0 & 0 & 0 & 0 \\
\hline Hot Water & WD & 0 & 0 & 0 & 0 & 10 & 10 & 50 & 50 & 50 & 50 & 70 & 90 & 90 & 50 & 50 & 70 & 50 & 50 & 50 & 10 & 10 & 10 & 10 & 0 \\
\hline \multirow[t]{2}{*}{ (\%) } & Sat & 0 & 0 & 0 & 0 & 0 & 0 & 10 & 20 & 20 & 20 & 20 & 20 & 20 & 20 & 20 & 20 & 20 & 10 & 10 & 10 & 0 & 0 & 0 & 0 \\
\hline & Sun & 0 & 0 & 0 & 0 & 0 & 0 & 0 & 10 & 10 & 10 & 10 & 10 & 10 & 10 & 10 & 10 & 10 & 10 & 10 & 10 & 0 & 0 & 0 & 0 \\
\hline
\end{tabular}


Table C-5. Hotel Function Occupancy Schedules (Table N2-6 from CEC 2004)

\begin{tabular}{|c|c|c|c|c|c|c|c|c|c|c|c|c|c|c|c|c|c|c|c|c|c|c|c|c|c|}
\hline & & \multicolumn{24}{|c|}{ Hour } \\
\hline & & 1 & 2 & 3 & 4 & 5 & 6 & 7 & 8 & 9 & 10 & 11 & 12 & 13 & 14 & 15 & 16 & 17 & 18 & 19 & 20 & 21 & 22 & 23 & 24 \\
\hline Heating & WD & 55 & 55 & 55 & 55 & 55 & 55 & 63 & 68 & 70 & 70 & 70 & 70 & 70 & 70 & 70 & 70 & 70 & 70 & 70 & 70 & 70 & 70 & 55 & 55 \\
\hline \multirow[t]{2}{*}{$\left({ }^{\circ} \mathrm{F}\right)$} & Sat & 55 & 55 & 55 & 55 & 55 & 55 & 63 & 68 & 70 & 70 & 70 & 70 & 70 & 70 & 70 & 70 & 70 & 70 & 70 & 70 & 70 & 70 & 55 & 55 \\
\hline & Sun & 55 & 55 & 55 & 55 & 55 & 55 & 63 & 68 & 70 & 70 & 70 & 70 & 70 & 70 & 70 & 70 & 70 & 70 & 70 & 70 & 70 & 70 & 55 & 55 \\
\hline Cooling & WD & 95 & 95 & 95 & 95 & 95 & 95 & 95 & 95 & 74 & 74 & 74 & 74 & 74 & 74 & 74 & 74 & 74 & 74 & 74 & 74 & 74 & 74 & 74 & 95 \\
\hline \multirow[t]{2}{*}{$\left({ }^{\circ} \mathrm{F}\right)$} & Sat & 95 & 95 & 95 & 95 & 95 & 95 & 95 & 95 & 74 & 74 & 74 & 74 & 74 & 74 & 74 & 74 & 74 & 74 & 74 & 74 & 74 & 74 & 74 & 95 \\
\hline & Sun & 95 & 95 & 95 & 95 & 95 & 95 & 95 & 95 & 74 & 74 & 74 & 74 & 74 & 74 & 74 & 74 & 74 & 74 & 74 & 74 & 74 & 74 & 74 & 95 \\
\hline Lights & WD & 5 & 5 & 5 & 5 & 5 & 5 & 5 & 5 & 25 & 50 & 90 & 90 & 90 & 90 & 90 & 90 & 75 & 50 & 50 & 50 & 50 & 10 & 5 & 5 \\
\hline \multirow[t]{2}{*}{ (\%) } & Sat & 5 & 5 & 5 & 5 & 5 & 5 & 5 & 5 & 25 & 50 & 90 & 90 & 90 & 90 & 90 & 90 & 75 & 50 & 50 & 50 & 50 & 10 & 5 & 5 \\
\hline & Sun & 5 & 5 & 5 & 5 & 5 & 5 & 5 & 5 & 25 & 50 & 90 & 90 & 90 & 90 & 90 & 90 & 75 & 50 & 50 & 50 & 50 & 10 & 5 & 5 \\
\hline Equipment & WD & 5 & 5 & 5 & 5 & 5 & 5 & 5 & 5 & 50 & 50 & 50 & 50 & 30 & 50 & 50 & 50 & 30 & 10 & 30 & 30 & 30 & 10 & 5 & 5 \\
\hline \multirow[t]{2}{*}{$(\%)$} & Sat & 5 & 5 & 5 & 5 & 5 & 5 & 5 & 5 & 50 & 50 & 50 & 50 & 30 & 50 & 50 & 50 & 30 & 10 & 30 & 30 & 30 & 10 & 5 & 5 \\
\hline & Sun & 5 & 5 & 5 & 5 & 5 & 5 & 5 & 5 & 50 & 50 & 50 & 50 & 30 & 50 & 50 & 50 & 30 & 10 & 30 & 30 & 30 & 10 & 5 & 5 \\
\hline \multirow[t]{3}{*}{ Fans } & WD & off & off & off & off & off & off & on & on & on & on & on & on & on & on & on & on & on & on & on & on & on & on & on & off \\
\hline & Sat & off & off & off & off & off & off & on & on & on & on & on & on & on & on & on & on & on & on & on & on & on & on & on & off \\
\hline & Sun & off & off & off & off & off & off & on & on & on & on & on & on & on & on & on & on & on & on & on & on & on & on & on & off \\
\hline Infiltration & WD & 100 & 100 & 100 & 100 & 100 & 100 & 0 & 0 & 0 & 0 & 0 & 0 & 0 & 0 & 0 & 0 & 0 & 0 & 0 & 0 & 0 & 0 & 0 & 100 \\
\hline \multirow[t]{2}{*}{ (\%) } & Sat & 100 & 100 & 100 & 100 & 100 & 100 & 0 & 0 & 0 & 0 & 0 & 0 & 0 & 0 & 0 & 0 & 0 & 0 & 0 & 0 & 0 & 0 & 0 & 100 \\
\hline & Sun & 100 & 100 & 100 & 100 & 100 & 100 & 0 & 0 & 0 & 0 & 0 & 0 & 0 & 0 & 0 & 0 & 0 & 0 & 0 & 0 & 0 & 0 & 0 & 100 \\
\hline People & WD & 0 & 0 & 0 & 0 & 0 & 0 & 0 & 5 & 35 & 90 & 90 & 90 & 25 & 90 & 90 & 90 & 50 & 25 & 50 & 50 & 50 & 10 & 0 & 0 \\
\hline \multirow[t]{2}{*}{ (\%) } & Sat & 0 & 0 & 0 & 0 & 0 & 0 & 0 & 5 & 35 & 90 & 90 & 90 & 25 & 90 & 90 & 90 & 50 & 25 & 50 & 50 & 50 & 10 & 0 & 0 \\
\hline & Sun & 0 & 0 & 0 & 0 & 0 & 0 & 0 & 5 & 35 & 90 & 90 & 90 & 25 & 90 & 90 & 90 & 50 & 25 & 50 & 50 & 50 & 10 & 0 & 0 \\
\hline Hot Water & WD & 0 & 0 & 0 & 0 & 0 & 0 & 0 & 5 & 35 & 90 & 90 & 90 & 25 & 90 & 90 & 90 & 50 & 25 & 50 & 50 & 50 & 10 & 0 & 0 \\
\hline \multirow[t]{2}{*}{$(\%)$} & Sat & 0 & 0 & 0 & 0 & 0 & 0 & 0 & 5 & 35 & 90 & 90 & 90 & 25 & 90 & 90 & 90 & 50 & 25 & 50 & 50 & 50 & 10 & 0 & 0 \\
\hline & Sun & 0 & 0 & 0 & 0 & 0 & 0 & 0 & 5 & 35 & 90 & 90 & 90 & 25 & 90 & 90 & 90 & 50 & 25 & 50 & 50 & 50 & 10 & 0 & 0 \\
\hline
\end{tabular}


Table C-6. Residential Occupancy Schedules (Including Hotel/Motel Guest Rooms) with Setback Thermostat for Heating (Table N2-7 from CEC 2004)

\begin{tabular}{|c|c|c|c|c|c|c|c|c|c|c|c|c|c|c|c|c|c|c|c|c|c|c|c|c|c|}
\hline & & \multicolumn{24}{|c|}{ Hour } \\
\hline & & 1 & 2 & 3 & 4 & 5 & 6 & 7 & 8 & 9 & 10 & 11 & 12 & 13 & 14 & 15 & 16 & 17 & 18 & 19 & 20 & 21 & 22 & 23 & 24 \\
\hline Heating & WD & 60 & 60 & 60 & 60 & 60 & 60 & 68 & 68 & 68 & 68 & 68 & 68 & 68 & 68 & 68 & 68 & 68 & 68 & 68 & 68 & 68 & 68 & 60 & 60 \\
\hline \multirow[t]{2}{*}{$\left({ }^{\circ} \mathrm{F}\right)$} & Sat & 60 & 60 & 60 & 60 & 60 & 60 & 68 & 68 & 68 & 68 & 68 & 68 & 68 & 68 & 68 & 68 & 68 & 68 & 68 & 68 & 68 & 68 & 60 & 60 \\
\hline & Sun & 60 & 60 & 60 & 60 & 60 & 60 & 68 & 68 & 68 & 68 & 68 & 68 & 68 & 68 & 68 & 68 & 68 & 68 & 68 & 68 & 68 & 68 & 60 & 60 \\
\hline Cooling & WD & 78 & 78 & 78 & 78 & 78 & 78 & 78 & 78 & 78 & 78 & 78 & 78 & 78 & 78 & 78 & 78 & 78 & 78 & 78 & 78 & 78 & 78 & 78 & 78 \\
\hline \multirow[t]{2}{*}{$\left({ }^{\circ} \mathrm{F}\right)$} & Sat & 78 & 78 & 78 & 78 & 78 & 78 & 78 & 78 & 78 & 78 & 78 & 78 & 78 & 78 & 78 & 78 & 78 & 78 & 78 & 78 & 78 & 78 & 78 & 78 \\
\hline & Sun & 78 & 78 & 78 & 78 & 78 & 78 & 78 & 78 & 78 & 78 & 78 & 78 & 78 & 78 & 78 & 78 & 78 & 78 & 78 & 78 & 78 & 78 & 78 & 78 \\
\hline Lights & WD & 10 & 10 & 10 & 10 & 10 & 30 & 45 & 45 & 45 & 45 & 30 & 30 & 30 & 30 & 30 & 30 & 30 & 30 & 60 & 80 & 90 & 80 & 60 & 30 \\
\hline \multirow[t]{2}{*}{$(\%)$} & Sat & 10 & 10 & 10 & 10 & 10 & 30 & 45 & 45 & 45 & 45 & 30 & 30 & 30 & 30 & 30 & 30 & 30 & 30 & 60 & 80 & 90 & 80 & 60 & 30 \\
\hline & Sun & 10 & 10 & 10 & 10 & 10 & 30 & 45 & 45 & 45 & 45 & 30 & 30 & 30 & 30 & 30 & 30 & 30 & 30 & 60 & 80 & 90 & 80 & 60 & 30 \\
\hline Equipment & WD & 10 & 10 & 10 & 10 & 10 & 30 & 45 & 45 & 45 & 45 & 30 & 30 & 30 & 30 & 30 & 30 & 30 & 30 & 60 & 80 & 90 & 80 & 60 & 30 \\
\hline \multirow[t]{2}{*}{ (\%) } & Sat & 10 & 10 & 10 & 10 & 10 & 30 & 45 & 45 & 45 & 45 & 30 & 30 & 30 & 30 & 30 & 30 & 30 & 30 & 60 & 80 & 90 & 80 & 60 & 30 \\
\hline & Sun & 10 & 10 & 10 & 10 & 10 & 30 & 45 & 45 & 45 & 45 & 30 & 30 & 30 & 30 & 30 & 30 & 30 & 30 & 60 & 80 & 90 & 80 & 60 & 30 \\
\hline \multirow[t]{3}{*}{ Fans } & WD & on & on & on & on & on & on & on & on & on & on & on & on & on & on & on & on & on & on & on & on & on & on & on & on \\
\hline & Sat & on & on & on & on & on & on & on & on & on & on & on & on & on & on & on & on & on & on & on & on & on & on & on & on \\
\hline & Sun & on & on & on & on & on & on & on & on & on & on & on & on & on & on & on & on & on & on & on & on & on & on & on & on \\
\hline Infiltration & WD & 100 & 100 & 100 & 100 & 100 & 100 & 100 & 100 & 100 & 100 & 100 & 100 & 100 & 100 & 100 & 100 & 100 & 100 & 100 & 100 & 100 & 100 & 100 & 100 \\
\hline \multirow[t]{2}{*}{$(\%)$} & Sat & 100 & 100 & 100 & 100 & 100 & 100 & 100 & 100 & 100 & 100 & 100 & 100 & 100 & 100 & 100 & 100 & 100 & 100 & 100 & 100 & 100 & 100 & 100 & 100 \\
\hline & Sun & 100 & 100 & 100 & 100 & 100 & 100 & 100 & 100 & 100 & 100 & 100 & 100 & 100 & 100 & 100 & 100 & 100 & 100 & 100 & 100 & 100 & 100 & 100 & 100 \\
\hline People & WD & 90 & 90 & 90 & 90 & 90 & 90 & 70 & 40 & 40 & 20 & 20 & 20 & 20 & 20 & 20 & 30 & 50 & 50 & 50 & 70 & 70 & 80 & 90 & 90 \\
\hline \multirow[t]{2}{*}{ (\%) } & Sat & 90 & 90 & 90 & 90 & 90 & 90 & 70 & 40 & 40 & 20 & 20 & 20 & 20 & 20 & 20 & 30 & 50 & 50 & 50 & 70 & 70 & 80 & 90 & 90 \\
\hline & Sun & 90 & 90 & 90 & 90 & 90 & 90 & 70 & 40 & 40 & 20 & 20 & 20 & 20 & 20 & 20 & 30 & 50 & 50 & 50 & 70 & 70 & 80 & 90 & 90 \\
\hline Hot Water & WD & 0 & 0 & 0 & 5 & 5 & 5 & 80 & 70 & 50 & 40 & 25 & 25 & 25 & 25 & 50 & 60 & 70 & 70 & 40 & 25 & 20 & 20 & 5 & 5 \\
\hline \multirow[t]{2}{*}{$(\%)$} & Sat & 0 & 0 & 0 & 5 & 5 & 5 & 80 & 70 & 50 & 40 & 25 & 25 & 25 & 25 & 50 & 60 & 70 & 70 & 40 & 25 & 20 & 20 & 5 & 5 \\
\hline & Sun & 0 & 0 & 0 & 5 & 5 & 5 & 80 & 70 & 50 & 40 & 25 & 25 & 25 & 25 & 50 & 60 & 70 & 70 & 40 & 25 & 20 & 20 & 5 & 5 \\
\hline
\end{tabular}


Table C-7. Residential Occupancy Schedules (Including Hotel/Motel Guest Rooms) without Setback Thermostat (Table N2-8 from CEC 2004)

\begin{tabular}{|c|c|c|c|c|c|c|c|c|c|c|c|c|c|c|c|c|c|c|c|c|c|c|c|c|c|}
\hline & & \multicolumn{24}{|c|}{ Hour } \\
\hline & & 1 & 2 & 3 & 4 & 5 & 6 & 7 & 8 & 9 & 10 & 11 & 12 & 13 & 14 & 15 & 16 & 17 & 18 & 19 & 20 & 21 & 22 & 23 & 24 \\
\hline eating & WD & 68 & 68 & 68 & 68 & 68 & 68 & 68 & 68 & 68 & 68 & 68 & 68 & 68 & 68 & 68 & 68 & 68 & 68 & 68 & 68 & 68 & 68 & 68 & 68 \\
\hline \multirow[t]{2}{*}{$\left({ }^{\circ} \mathrm{F}\right)$} & Sat & 68 & 68 & 68 & 68 & 68 & 68 & 68 & 68 & 68 & 68 & 68 & 68 & 68 & 68 & 68 & 68 & 68 & 68 & 68 & 68 & 68 & 68 & 68 & 68 \\
\hline & Sun & 68 & 68 & 68 & 68 & 68 & 68 & 68 & 68 & 68 & 68 & 68 & 68 & 68 & 68 & 68 & 68 & 68 & 68 & 68 & 68 & 68 & 68 & 68 & 68 \\
\hline Cooling & WD & 78 & 78 & 78 & 78 & 78 & 78 & 78 & 78 & 78 & 78 & 78 & 78 & 78 & 78 & 78 & 78 & 78 & 78 & 78 & 78 & 78 & 78 & 78 & 78 \\
\hline \multirow[t]{2}{*}{$\left({ }^{\circ} \mathrm{F}\right)$} & Sat & 78 & 78 & 78 & 78 & 78 & 78 & 78 & 78 & 78 & 78 & 78 & 78 & 78 & 78 & 78 & 78 & 78 & 78 & 78 & 78 & 78 & 78 & 78 & 78 \\
\hline & Sun & 78 & 78 & 78 & 78 & 78 & 78 & 78 & 78 & 78 & 78 & 78 & 78 & 78 & 78 & 78 & 78 & 78 & 78 & 78 & 78 & 78 & 78 & 78 & 78 \\
\hline Lights & WD & 10 & 10 & 10 & 10 & 10 & 30 & 45 & 45 & 45 & 45 & 30 & 30 & 30 & 30 & 30 & 30 & 30 & 30 & 60 & 80 & 90 & 80 & 60 & 30 \\
\hline \multirow[t]{2}{*}{ (\%) } & Sat & 10 & 10 & 10 & 10 & 10 & 30 & 45 & 45 & 45 & 45 & 30 & 30 & 30 & 30 & 30 & 30 & 30 & 30 & 60 & 80 & 90 & 80 & 60 & 30 \\
\hline & Sun & 10 & 10 & 10 & 10 & 10 & 30 & 45 & 45 & 45 & 45 & 30 & 30 & 30 & 30 & 30 & 30 & 30 & 30 & 60 & 80 & 90 & 80 & 60 & 30 \\
\hline quipmer & WD & 10 & 10 & 10 & 10 & 10 & 30 & 45 & 45 & 45 & 45 & 30 & 30 & 30 & 30 & 30 & 30 & 30 & 30 & 60 & 80 & 90 & 80 & 60 & 30 \\
\hline \multirow[t]{2}{*}{ (\%) } & Sat & 10 & 10 & 10 & 10 & 10 & 30 & 45 & 45 & 45 & 45 & 30 & 30 & 30 & 30 & 30 & 30 & 30 & 30 & 60 & 80 & 90 & 80 & 60 & 30 \\
\hline & Sun & 10 & 10 & 10 & 10 & 10 & 30 & 45 & 45 & 45 & 45 & 30 & 30 & 30 & 30 & 30 & 30 & 30 & 30 & 60 & 80 & 90 & 80 & 60 & 30 \\
\hline \multirow[t]{3}{*}{ Fans } & WD & on & on & on & on & on & on & on & on & on & on & on & on & on & on & on & on & on & on & on & on & on & on & on & on \\
\hline & Sat & on & on & on & on & on & on & on & on & on & on & on & on & on & on & on & on & on & on & on & on & on & on & on & on \\
\hline & Sun & on & on & on & on & on & on & on & on & on & on & on & on & on & on & on & on & on & on & on & on & on & on & on & on \\
\hline Infiltration & WD & 100 & 100 & 100 & 100 & 100 & 100 & 100 & 100 & 100 & 100 & 100 & 100 & 100 & 100 & 100 & 100 & 100 & 100 & 100 & 100 & 100 & 100 & 100 & 100 \\
\hline \multirow[t]{2}{*}{ (\%) } & Sat & 100 & 100 & 100 & 100 & 100 & 100 & 100 & 100 & 100 & 100 & 100 & 100 & 100 & 100 & 100 & 100 & 100 & 100 & 100 & 100 & 100 & 100 & 100 & 100 \\
\hline & Sun & 100 & 100 & 100 & 100 & 100 & 100 & 100 & 100 & 100 & 100 & 100 & 100 & 100 & 100 & 100 & 100 & 100 & 100 & 100 & 100 & 100 & 100 & 100 & 100 \\
\hline People & WD & 90 & 90 & 90 & 90 & 90 & 90 & 70 & 40 & 40 & 20 & 20 & 20 & 20 & 20 & 20 & 30 & 50 & 50 & 50 & 70 & 70 & 80 & 90 & 90 \\
\hline \multirow[t]{2}{*}{ (\%) } & Sat & 90 & 90 & 90 & 90 & 90 & 90 & 70 & 40 & 40 & 20 & 20 & 20 & 20 & 20 & 20 & 30 & 50 & 50 & 50 & 70 & 70 & 80 & 90 & 90 \\
\hline & Sun & 90 & 90 & 90 & 90 & 90 & 90 & 70 & 40 & 40 & 20 & 20 & 20 & 20 & 20 & 20 & 30 & 50 & 50 & 50 & 70 & 70 & 80 & 90 & 90 \\
\hline Hot Water & WD & 0 & 0 & 0 & 5 & 5 & 5 & 80 & 70 & 50 & 40 & 25 & 25 & 25 & 25 & 50 & 60 & 70 & 70 & 40 & 25 & 20 & 20 & 5 & 5 \\
\hline \multirow[t]{2}{*}{$(\%)$} & Sat & 0 & 0 & 0 & 5 & 5 & 5 & 80 & 70 & 50 & 40 & 25 & 25 & 25 & 25 & 50 & 60 & 70 & 70 & 40 & 25 & 20 & 20 & 5 & 5 \\
\hline & Sun & 0 & 0 & 0 & 5 & 5 & 5 & 80 & 70 & 50 & 40 & 25 & 25 & 25 & 25 & 50 & 60 & 70 & 70 & 40 & 25 & 20 & 20 & 5 & 5 \\
\hline
\end{tabular}


Table C-8. Retail Occupancy Schedules (Table N2-9 from CEC 2004)

\begin{tabular}{|c|c|c|c|c|c|c|c|c|c|c|c|c|c|c|c|c|c|c|c|c|c|c|c|c|c|}
\hline & & \multicolumn{24}{|c|}{ Hour } \\
\hline & & 1 & 2 & 3 & 4 & 5 & 6 & 7 & 8 & 9 & 10 & 11 & 12 & 13 & 14 & 15 & 16 & 17 & 18 & 19 & 20 & 21 & 22 & 23 & 24 \\
\hline Heating & WD & 60 & 60 & 60 & 60 & 60 & 63 & 65 & 68 & 70 & 70 & 70 & 70 & 70 & 70 & 70 & 70 & 70 & 70 & 70 & 65 & 65 & 65 & 65 & 60 \\
\hline \multirow[t]{2}{*}{$\left({ }^{\circ} \mathrm{F}\right)$} & Sat & 60 & 60 & 60 & 60 & 60 & 63 & 65 & 68 & 70 & 70 & 70 & 70 & 70 & 70 & 70 & 70 & 70 & 70 & 70 & 65 & 65 & 65 & 65 & 60 \\
\hline & Sun & 60 & 60 & 60 & 60 & 60 & 63 & 65 & 68 & 70 & 70 & 70 & 70 & 70 & 70 & 70 & 70 & 70 & 70 & 70 & 65 & 65 & 65 & 65 & 60 \\
\hline Cooling & WD & 80 & 80 & 80 & 80 & 80 & 74 & 74 & 74 & 74 & 74 & 74 & 74 & 74 & 74 & 74 & 74 & 74 & 74 & 74 & 74 & 74 & 74 & 80 & 80 \\
\hline \multirow[t]{2}{*}{$\left({ }^{\circ} \mathrm{F}\right)$} & Sat & 80 & 80 & 80 & 80 & 80 & 74 & 74 & 74 & 74 & 74 & 74 & 74 & 74 & 74 & 74 & 74 & 74 & 74 & 74 & 74 & 74 & 74 & 80 & 80 \\
\hline & Sun & 80 & 80 & 80 & 80 & 80 & 74 & 74 & 74 & 74 & 74 & 74 & 74 & 74 & 74 & 74 & 74 & 74 & 74 & 74 & 74 & 74 & 74 & 80 & 80 \\
\hline Lights & WD & 20 & 20 & 20 & 20 & 20 & 30 & 40 & 65 & 90 & 90 & 90 & 90 & 90 & 90 & 90 & 90 & 90 & 90 & 90 & 80 & 65 & 50 & 35 & 25 \\
\hline \multirow[t]{2}{*}{ (\%) } & Sat & 20 & 20 & 20 & 20 & 20 & 30 & 40 & 65 & 90 & 90 & 90 & 90 & 90 & 90 & 90 & 90 & 90 & 90 & 90 & 80 & 65 & 50 & 35 & 25 \\
\hline & Sun & 20 & 20 & 20 & 20 & 20 & 30 & 40 & 65 & 90 & 90 & 90 & 90 & 90 & 90 & 90 & 90 & 90 & 90 & 90 & 80 & 65 & 50 & 35 & 25 \\
\hline Equipment & WD & 20 & 20 & 20 & 20 & 20 & 25 & 30 & 45 & 60 & 75 & 75 & 75 & 70 & 75 & 75 & 75 & 75 & 75 & 65 & 55 & 45 & 35 & 25 & 20 \\
\hline \multirow[t]{2}{*}{ (\%) } & Sat & 20 & 20 & 20 & 20 & 20 & 25 & 30 & 45 & 60 & 75 & 75 & 75 & 70 & 75 & 75 & 75 & 75 & 75 & 65 & 55 & 45 & 35 & 25 & 20 \\
\hline & Sun & 20 & 20 & 20 & 20 & 20 & 25 & 30 & 45 & 60 & 75 & 75 & 75 & 70 & 75 & 75 & 75 & 75 & 75 & 65 & 55 & 45 & 35 & 25 & 20 \\
\hline \multirow[t]{3}{*}{ Fans } & WD & off & off & off & off & off & on & on & on & on & on & on & on & on & on & on & on & on & on & on & on & on & off & off & off \\
\hline & Sat & off & off & off & off & off & on & on & on & on & on & on & on & on & on & on & on & on & on & on & on & on & off & off & off \\
\hline & Sun & off & off & off & off & off & on & on & on & on & on & on & on & on & on & on & on & on & on & on & on & on & off & off & off \\
\hline Infiltration & WD & 100 & 100 & 100 & 100 & 100 & 0 & 0 & 0 & 0 & 0 & 0 & 0 & 0 & 0 & 0 & 0 & 0 & 0 & 0 & 0 & 0 & 100 & 100 & 100 \\
\hline \multirow[t]{2}{*}{$(\%)$} & Sat & 100 & 100 & 100 & 100 & 100 & 0 & 0 & 0 & 0 & 0 & 0 & 0 & 0 & 0 & 0 & 0 & 0 & 0 & 0 & 0 & 0 & 100 & 100 & 100 \\
\hline & Sun & 100 & 100 & 100 & 100 & 100 & 0 & 0 & 0 & 0 & 0 & 0 & 0 & 0 & 0 & 0 & 0 & 0 & 0 & 0 & 0 & 0 & 100 & 100 & 100 \\
\hline People & WD & 5 & 5 & 5 & 5 & 5 & 5 & 15 & 25 & 40 & 55 & 75 & 75 & 75 & 75 & 75 & 75 & 75 & 75 & 65 & 50 & 35 & 20 & 10 & 5 \\
\hline \multirow[t]{2}{*}{ (\%) } & Sat & 5 & 5 & 5 & 5 & 5 & 5 & 15 & 25 & 40 & 55 & 75 & 75 & 75 & 75 & 75 & 75 & 75 & 75 & 65 & 50 & 35 & 20 & 10 & 5 \\
\hline & Sun & 5 & 5 & 5 & 5 & 5 & 5 & 15 & 25 & 40 & 55 & 75 & 75 & 75 & 75 & 75 & 75 & 75 & 75 & 65 & 50 & 35 & 20 & 10 & 5 \\
\hline Hot Water & WD & 0 & 0 & 0 & 0 & 0 & 0 & 10 & 10 & 50 & 50 & 70 & 90 & 90 & 50 & 50 & 70 & 50 & 50 & 50 & 10 & 10 & 0 & 0 & 0 \\
\hline \multirow[t]{2}{*}{$(\%)$} & Sat & 0 & 0 & 0 & 0 & 0 & 0 & 10 & 10 & 50 & 50 & 70 & 90 & 90 & 50 & 50 & 70 & 50 & 50 & 50 & 10 & 10 & 0 & 0 & 0 \\
\hline & Sun & 0 & 0 & 0 & 0 & 0 & 0 & 10 & 10 & 50 & 50 & 70 & 90 & 90 & 50 & 50 & 70 & 50 & 50 & 50 & 10 & 10 & 0 & 0 & 0 \\
\hline
\end{tabular}




\section{Appendix D. Illuminance Categories and Luminaire Power from the 2005 California Nonresidential ACM Approval Manual}

\section{NONRESIDENTIAL ACM MANUAL APPENDIX NB}

\section{Appendix NB - Illuminance Categories and Luminaire Power}

\section{IIluminance Categories}

Please see Chapter 10 in the IESNA Lighting Handbook, Ninth Edition.

\section{Illuminance Categories and Luminaire Power}

Luminaire power shall be taken from the following tables.

Table NB-1 - Fluorescent Circline

Table NB-2 - Compact Fluorescent 2D

Table NB-3 - Compact Fluorescent

Table NB-4 -Long Compact Fluorescent

Table NB-5 - Fluorescent U-Tubes

Table NB-6 - Fluorescent Linear Lamps - Preheat

Table NB-7 - Fluorescent Linear Lamps T5

Table NB-8 - Fluorescent Rapid Start T-8

Table NB-9 - Fluorescent Rapid Start T-12

Table NB-10 - Fluorescent Rapid Start High Output (HO) T8 \& T12, 8 ft

Table NB-11 - Fluorescent Instant Start (single pin base "Slimline") T12, 4 ft

Table NB-12 - Fluorescent Instant Start (single pin base "Slimline") T8 \& T12, $8 \mathrm{ft}$.

Table NB-13 - High Intensity Discharge

Table NB-14 - 12 Volt Tungsten Halogen Lamps Including MR16, Bi-pin, AR70, AR111, PAR36

Appendix NB - Illuminance Categories and Luminaire Power 
Table NB-1 - Fluorescent Circline

\begin{tabular}{|c|c|c|c|c|c|c|c|}
\hline \multirow[b]{2}{*}{ Type } & \multirow[b]{2}{*}{ Number } & \multicolumn{2}{|l|}{ Lamps } & \multicolumn{2}{|c|}{ Ballasts } & \multirow{2}{*}{$\begin{array}{l}\text { - System } \\
\text { Watts }\end{array}$} & \multirow[b]{2}{*}{ Comment } \\
\hline & & Designation & Number & Designation & Description & & \\
\hline Rapid Start (22 W) & 1 & FC8T9 & 1 & MAG STAND. & Mag. Stand. & 27 & $8 " \mathrm{OD}$ \\
\hline \multirow[t]{2}{*}{ T5 Program Start (22 W) } & 1 & FC9T5 & 1 & ELECTNO & Electronic Normal Light & 28 & $8 " \mathrm{OD}$ \\
\hline & 2 & FC9T5 & 1 & ELECTNO & Electronic Normal Light & 53 & \\
\hline \multirow[t]{2}{*}{ T5 Program Start (40 W) } & 1 & FC12T5 & 1 & ELECT NO & Electronic Normal Light & 41 & $12^{\prime \prime} \mathrm{OD}$ \\
\hline & 2 & FC12T5 & 1 & ELECT NO & Electronic Normal Light & 80 & \\
\hline \multirow[t]{4}{*}{ T5 Rapid Start (55 W) } & 1 & $\mathrm{FC} 12 \mathrm{~T} 5 \mathrm{HO}$ & 1 & ELECT NO & Electronic Normal Light & 55 & $12^{\prime \prime} \mathrm{OD}$ \\
\hline & 2 & FC12Tag5HO & 1 & ELECT NO & Electronic Normal Light & 103 & \\
\hline & 1 & $\mathrm{FC} 12 \mathrm{~T} 5 \mathrm{HO}$ & 1 & ELECT DIM & Electronic Dimming & $12 \sim 59$ & \\
\hline & 2 & $\mathrm{FC} 12 \mathrm{~T} 5 \mathrm{HO}$ & 1 & ELECT DIM & Electronic Dimming & $24 \sim 114$ & \\
\hline T5 Rapid Start $(40+22$ & $1+1$ & FC12T5/FC9T5 & 1 & ELECT NO & Electronic Normal Light & 68 & $8^{\prime \prime} \& 12^{\prime}$ \\
\hline
\end{tabular}
W)

$\mathrm{RO}=$ ballast factor 70 to $85 \% \quad \mathrm{NO}=$ ballast factor 85 to $100 \% \quad \mathrm{HO}=$ ballast factor $>100 \%$

Table NB-2 - Compact Fluorescent 2D

\begin{tabular}{|c|c|c|c|c|c|c|c|}
\hline \multirow[b]{2}{*}{ Type } & \multicolumn{3}{|c|}{ Lamps } & \multicolumn{2}{|c|}{ Ballasts } & \multirow{2}{*}{$\begin{array}{l}\text {-System } \\
\text { Watts }\end{array}$} & \multirow[b]{2}{*}{ Comment } \\
\hline & Number & Designation & Number & Designation & Description & & \\
\hline \multirow{3}{*}{$\begin{array}{l}\text { 10W, } \\
\text { GR10q-4 Four Pin Base }\end{array}$} & 1 & CFS10W/GR10q & 1 & MAG STD & Mag. Stand. & 16 & $3.6^{\prime \prime}$ across \\
\hline & 1 & CFS10W/GR10q & 1 & ELECT & Electronic & 13 & \\
\hline & 2 & CFS10W/GR10q & 1 & ELECT & Electronic & 26 & \\
\hline \multirow{3}{*}{$\begin{array}{l}\text { 16W, } \\
\text { GR10q-4 Four Pin Base }\end{array}$} & 1 & CFS16W/GR10q & 1 & MAG STD & Mag. Stand. & 23 & $5.5^{\prime \prime}$ across \\
\hline & 1 & CFS16W/GR10q & 1 & EEECT & Electronic & 15 & \\
\hline & 2 & CFS16W/GR10q & 1 & ELECT & Electronic & 30 & \\
\hline \multirow{3}{*}{$\begin{array}{l}21 W, \\
\text { GR10q-4 Four Pin Base }\end{array}$} & 1 & CFS21W/GR10q & 1 & MAG STD & Mag. Stand. & 31 & $5.5^{\prime \prime}$ across \\
\hline & 1 & CFS21W/GR10q & 1 & ELECT & Electronic & 21 & \\
\hline & 2 & CFS21W/GR10q & 1 & ELECT & Electronic & 42 & \\
\hline \multirow{3}{*}{$\begin{array}{l}28 W, \\
\text { GR10q-4 Four Pin Base }\end{array}$} & 1 & CFS28W/GR10q & 1 & MAG STD & Mag. Stand. & 38 & 8.1" across \\
\hline & 1 & CFS28W/GR10q & 1 & ELECT & Electronic & 28 & \\
\hline & 2 & CFS28W/GR10q & 1 & EEECT & Electronic & 56 & \\
\hline \multirow{2}{*}{$\begin{array}{l}38 \mathrm{~W}, \\
\text { GR10q-4 Four Pin Base }\end{array}$} & 1 & CFS38W/GR10q & 1 & ELECT & Electronic & 37 & 8.1" across \\
\hline & 2 & CFS38W/GR10q & 1 & ELECT & Electronic & 74 & \\
\hline
\end{tabular}

$\mathrm{RO}=$ ballast factor 70 to $85 \% \quad \mathrm{NO}=$ ballast factor 85 to $100 \% \quad \mathrm{HO}=$ ballast factor $>100 \%$ 
Table NB-3 - Compact Fluorescent

\begin{tabular}{|c|c|c|c|c|c|c|c|}
\hline \multirow[b]{2}{*}{ Type } & \multicolumn{3}{|c|}{ Lamps } & \multicolumn{2}{|c|}{ Ballasts } & \multirow{2}{*}{$\begin{array}{l}\text { System } \\
\text { Watts }\end{array}$} & \multirow[b]{2}{*}{ Comment } \\
\hline & Number & Designation & Number & Designation & Description & & \\
\hline \multirow{2}{*}{$\begin{array}{l}\text { Twin ( } 5 \mathrm{~W} \text {, } \\
\text { G23 Two Pin Base - } \\
\text { F5TT Lamp) }\end{array}$} & 1 & CFT5W/G23 & 1 & MAG STD & Mag. Stand. & 9 & 4.1" MOL \\
\hline & 2 & CFT5W/G23 & 2 & MAG STD & Mag. Stand. & 18 & \\
\hline \multirow{2}{*}{$\begin{array}{l}\text { Twin ( } 7 \mathrm{~W} \text {, } \\
\text { G23 Two Pin Base - } \\
\text { F7TT Lamp) }\end{array}$} & 1 & CFT7W/G23 & 1 & MAG STD & Mag. Stand. & 11 & 5.3" MOL \\
\hline & 2 & CFT7W/G23 & 2 & MAG STD & Mag. Stand. & 22 & \\
\hline \multirow{2}{*}{$\begin{array}{l}\text { Twin }(7 \mathrm{~W} \text {, } \\
2 \mathrm{G} 7 \text { Four Pin Base - } \\
\text { F7TT Lamp) }\end{array}$} & 1 & CFT7W/2G7 & 1 & ELECT & Electronic & 8 & $5.3^{\prime \prime} \mathrm{MOL}$ \\
\hline & 2 & CFT7W/2G7 & 2 & ELECT & Electronic & 16 & \\
\hline \multirow{2}{*}{$\begin{array}{l}\text { Twin ( } 9 \mathrm{~W} \text {, } \\
\text { G23 Two Pin Base - } \\
\text { F9TT Lamp) }\end{array}$} & 1 & CFT9W/G23 & 1 & MAG STD & Mag. Stand. & 13 & $6.5^{\prime \prime} \mathrm{MOL}$ \\
\hline & 2 & CFT9W/G23 & 2 & MAG STD & Mag. Stand. & 26 & \\
\hline \multirow{2}{*}{$\begin{array}{l}\text { Twin ( } 9 \mathrm{~W} \text {, } \\
\text { 2G7 Four Pin Base - } \\
\text { F9TT Lamp) }\end{array}$} & 1 & CFT9W/2G7 & 1 & ELECT & Electronic & 10 & $6.5^{\prime \prime} \mathrm{MOL}$ \\
\hline & 2 & CFT9W/2G7 & 2 & ELECT & Electronic & 20 & \\
\hline \multirow{2}{*}{$\begin{array}{l}\text { Twin }(13 \text { W, } \\
\text { GX23 Two Pin Base - } \\
\text { F13TT) }\end{array}$} & 1 & CFT13W/GX23 & 1 & MAG STD & Mag. Stand. & 17 & 7.5" MOL \\
\hline & 2 & CFT13W/GX23 & 2 & MAG STD & Mag. Stand. & 34 & \\
\hline \multirow{2}{*}{$\begin{array}{l}\text { Twin ( } 13 \text { W, } \\
\text { 2GX7 Four Pin Base - } \\
\text { F13TT) }\end{array}$} & 1 & CFT13W/2GX7 & 1 & ELECT & Electronic & 17 & $7.5^{\mathrm{n}} \mathrm{MOL}$ \\
\hline & 2 & CFT13W/2GX7 & 2 & ELECT & Electronic & 34 & \\
\hline \multirow{2}{*}{$\begin{array}{l}\text { Quad ( } 9 \mathrm{~W} \text {, } \\
\text { G23-2 Two Pin Base - } \\
\text { F9DTT Lamp) }\end{array}$} & 1 & CFQ9W/G23-2 & 1 & MAG STD 120 & 120 V Mag. Stand. & 13 & 4.4" MOL \\
\hline & 2 & CFQ9WIG23-2 & 2 & MAG STD 120 & 120 V Mag. Stand. & 26 & \\
\hline \multirow{4}{*}{$\begin{array}{l}\text { Quad ( } 13 \text { W, } \\
\text { G24d-1 Two Pin Base - } \\
\text { F13DTT Lamp) }\end{array}$} & 1 & $\begin{array}{l}\text { CFQ13W/G24d } \\
-1\end{array}$ & & MAG STD 120 & 120 V Mag. Stand. & 18 & $6.0^{\prime \prime} \mathrm{MOL}$ \\
\hline & 2 & $\begin{array}{l}\text { CFQ13W/G24d } \\
-1\end{array}$ & & MAG STD 120 & 120 V Mag. Stand. & 36 & \\
\hline & 1 & $\begin{array}{l}\text { CFQ13W/G24d } \\
-1\end{array}$ & & MAG STD 277 & 277 V Mag. Stand. & 16 & \\
\hline & 2 & $\begin{array}{l}\text { CFQ13W/G24d } \\
-1\end{array}$ & & MAG STD 277 & 227 V Mag. Stand. & 32 & \\
\hline \multirow[t]{2}{*}{$\begin{array}{l}\text { Quad (13 W, } \\
\text { GX23-2 Two Pin Base) }\end{array}$} & 1 & $\begin{array}{l}\text { CFQ13W/GX2 } \\
3-2\end{array}$ & 1 & MAG STD & Mag. Stand. & 17 & $4.8^{\prime \prime} \mathrm{MOL}$ \\
\hline & 2 & $\begin{array}{l}\text { CFQ13W/GX2 } \\
3-2\end{array}$ & 2 & MAG STD & Mag. Stand. & 34 & \\
\hline \multirow[t]{2}{*}{$\begin{array}{l}\text { Quad (16W } \\
\text { GX32d-1 Two Pin Base) }\end{array}$} & 1 & $\begin{array}{l}\text { CFQ16W/GX3 } \\
\text { 2d-1 }\end{array}$ & 1 & MAG STD & Mag. Stand. & 20 & $5.5^{\prime \prime} \mathrm{MOL}$ \\
\hline & 2 & $\begin{array}{l}\text { CFQ16W/GX3 } \\
\text { 2d-1 }\end{array}$ & 2 & MAG STD & Mag. Stand. & 40 & \\
\hline \multirow{3}{*}{$\begin{array}{l}\text { Quad ( } 18 \text { W, } \\
\text { G24d-2 Two Pin Base - } \\
\text { F18DTT Lamp) }\end{array}$} & 1 & $\begin{array}{l}\text { CFQ18W/G24d } \\
-2\end{array}$ & & MAG STD 120 & 120 V Mag. Stand. & 25 & $6.8^{\prime \prime} \mathrm{MOL}$ \\
\hline & 2 & $\begin{array}{l}\text { CFQ18W/G24d } \\
-2\end{array}$ & & MAG STD 120 & $120 \mathrm{~V}$ Mag. Stand. & 50 & \\
\hline & 1 & $\begin{array}{l}\text { CFQ18W/G24d } \\
-2\end{array}$ & 1 & MAG STD 277 & 227 V Mag. Stand. & 22 & \\
\hline
\end{tabular}

Appendix NB - Illuminance Categories and Luminaire Power 


\begin{tabular}{|c|c|c|c|c|c|c|c|}
\hline \multirow{4}{*}{ Type } & \multicolumn{2}{|r|}{ Lamps } & \multicolumn{3}{|c|}{ Ballasts } & \multirow{2}{*}{$\begin{array}{l}\text { System } \\
\text { Watts }\end{array}$} & \multirow[b]{2}{*}{ Comment } \\
\hline & Number & Designation & Number & Designation & Description & & \\
\hline & 2 & $\begin{array}{l}\text { CFQ18W/G24d } \\
-2\end{array}$ & & MAG STD 277 & 227 V Mag. Stand. & 44 & \\
\hline & 1 & $\begin{array}{l}\text { CFQ22W/GX3 } \\
2 \mathrm{~d}-2\end{array}$ & 1 & MAG STD & Mag. Stand. & 27 & 6.0" MOL \\
\hline $\begin{array}{l}\text { Quad (22W, } \\
\text { GX32d Two Pin Base) }\end{array}$ & 2 & $\begin{array}{l}\text { CFQ22W/GX3 } \\
2 \mathrm{~d}-2\end{array}$ & 2 & MAG STD & Mag. Stand. & 54 & \\
\hline \multirow{6}{*}{$\begin{array}{l}\text { Quad ( } 26 \text { W, } \\
\text { G24d-3 Two Pin Base - } \\
\text { F26DTT Lamp) }\end{array}$} & 1 & $\begin{array}{l}\text { CFQ26W/G24d } \\
-3\end{array}$ & & MAG STD 120 & 120 V Mag. Stand. & 37 & $7.6^{\prime \prime} \mathrm{MOL}$ \\
\hline & 2 & $\begin{array}{l}\text { CFQ26W/G24d } \\
-3\end{array}$ & & MAG STD 120 & 120 V Mag. Stand. & 74 & \\
\hline & 1 & $\begin{array}{l}\text { CFQ26W/G24d } \\
-3\end{array}$ & & MAG STD 277 & 227 V Mag. Stand. & 33 & \\
\hline & 2 & $\begin{array}{l}\text { CFQ26W/G24d } \\
-3\end{array}$ & & MAG STD 277 & 227 V Mag. Stand. & 66 & \\
\hline & 1 & $\begin{array}{l}\text { CFQ26W/G24d } \\
-3\end{array}$ & & ELECT $277 \mathrm{~V}$ & 277 V Electronic & 27 & \\
\hline & 2 & $\begin{array}{l}\text { CFQ26W/G24d } \\
-3\end{array}$ & & ELECT $277 \mathrm{~V}$ & 277 V Electronic & 54 & \\
\hline \multirow[t]{2}{*}{$\begin{array}{l}\text { Quad ( } 28 W \\
\text { GX32d Two Pin Base) }\end{array}$} & 1 & $\begin{array}{l}\text { CFQ28W/GX3 } \\
2 \mathrm{~d}-3\end{array}$ & 1 & MAG STD & Mag. Stand. & 34 & $6.8^{\prime \prime} \mathrm{MOL}$ \\
\hline & 2 & $\begin{array}{l}\text { CFQ28W/GX3 } \\
2 \mathrm{~d}-3\end{array}$ & 2 & MAG STD & Mag. Stand. & 68 & \\
\hline \multirow[t]{4}{*}{$\begin{array}{l}\text { Quad (10 W, } \\
\text { G24q-1 Four Pin Base) }\end{array}$} & 1 & $\begin{array}{l}\text { CFQ10W/G24q } \\
-1\end{array}$ & & MAG STD 120 & 120 V Mag. Stand. & 16 & 4.6" MOL \\
\hline & 2 & $\begin{array}{l}\text { CFQ10W/G24q } \\
-1\end{array}$ & & MAG STD 120 & 120 V Mag. Stand. & 32 & \\
\hline & 1 & $\begin{array}{l}\text { CFQ10W/G24q } \\
-1\end{array}$ & & MAG STD 277 & 227 V Mag. Stand. & 13 & \\
\hline & 2 & $\begin{array}{l}\text { CFQ10W/G24q } \\
-1\end{array}$ & & MAG STD 277 & 227 V Mag. Stand. & 26 & \\
\hline \multirow[t]{6}{*}{$\begin{array}{l}\text { Quad ( } 13 \mathrm{~W}, \\
\text { G24q-1 Four Pin Base) }\end{array}$} & 1 & $\begin{array}{l}\text { CFQ13W/G24q } \\
-1\end{array}$ & & MAG STD 120 & 120 V Mag. Stand. & 18 & $6.0^{\prime \prime} \mathrm{MOL}$ \\
\hline & 2 & $\begin{array}{l}\text { CFQ13W/G24q } \\
-1\end{array}$ & & MAG STD 120 & 120 V Mag. Stand. & 36 & \\
\hline & 1 & $\begin{array}{l}\text { CFQ13W/G24q } \\
-1\end{array}$ & & MAG STD 277 & 227 V Mag. Stand. & 16 & \\
\hline & 2 & $\begin{array}{l}\text { CFQ13W/G24q } \\
-1\end{array}$ & & MAG STD 277 & 227 V Mag. Stand. & 32 & \\
\hline & 1 & $\begin{array}{l}\text { CFQ13W/G24q } \\
-1\end{array}$ & & ELECT & Electronic & 14 & \\
\hline & 2 & $\begin{array}{l}\text { CFQ13W/G24q } \\
-1\end{array}$ & & ELECT & Electronic & 25 & \\
\hline \multirow{2}{*}{$\begin{array}{l}\text { Quad (13 W, } \\
\text { GX7 Four Pin Base) }\end{array}$} & 1 & CFQ13W/GX7 & 1 & MAG STD & Mag. Stand. & 17 & 4.8" MOL \\
\hline & 2 & CFQ13W/GX7 & 2 & MAG STD & Mag. Stand. & 34 & \\
\hline $\begin{array}{l}\text { Quad (18 W, } \\
\text { G24q-2 Four Pin Base) }\end{array}$ & 1 & $\begin{array}{l}\text { CFQ18W/G24q } \\
-2\end{array}$ & & MAG STD 120 & 120 V Mag. Stand. & 25 & $6.8^{\prime \prime} \mathrm{MOL}$ \\
\hline
\end{tabular}

Appendix NB - Illuminance Categories and Luminaire Power 


\begin{tabular}{|c|c|c|c|c|c|c|c|}
\hline \multirow{7}{*}{ Type } & \multicolumn{2}{|r|}{ Lamps } & \multicolumn{3}{|c|}{ Ballasts } & \multirow{2}{*}{$\begin{array}{l}\text { System } \\
\text { Watts }\end{array}$} & \multirow[b]{2}{*}{ Comment } \\
\hline & Number & Designation & Number & Designation & Description & & \\
\hline & 2 & $\begin{array}{l}\text { CFQ18W/G24q } \\
-2\end{array}$ & & MAG STD 120 & $120 \mathrm{~V}$ Mag. Stand. & 50 & \\
\hline & 1 & $\begin{array}{l}\text { CFQ18W/G24q } \\
-2\end{array}$ & & MAG STD 277 & 227 V Mag. Stand. & 22 & \\
\hline & 2 & $\begin{array}{l}\text { CFQ18W/G24q } \\
-2\end{array}$ & & MAG STD 277 & 227 V Mag. Stand. & 44 & \\
\hline & 1 & $\begin{array}{l}\text { CFQ18W/G24q } \\
-2\end{array}$ & & ELECT & Electronic & 21 & \\
\hline & 2 & $\begin{array}{l}\text { CFQ18W/G24q } \\
-2\end{array}$ & & ELECT & Electronic & 38 & \\
\hline \multirow{4}{*}{$\begin{array}{l}\text { Triple (13 W, } \\
\text { GX24q-1 Four Pin } \\
\text { Base) }\end{array}$} & 1 & $\begin{array}{l}\text { CFM } \\
13 W / G \times 24 q-1\end{array}$ & 1 & MAG STD & Mag. Stand. & 18 & $4.2^{1 "} \mathrm{MOL}$ \\
\hline & 2 & $\begin{array}{l}\text { CFM } \\
13 W / G \times 24 q-1\end{array}$ & 2 & MAG STD & Mag. Stand. & 36 & \\
\hline & 1 & $\begin{array}{l}\text { CFM } \\
13 W / G \times 24 q-1\end{array}$ & 1 & ELECT & Electronic & 14 & \\
\hline & 2 & $\begin{array}{l}\text { CFM } \\
13 W / G \times 24 q-1\end{array}$ & 2 & ELECT & Electronic & 25 & \\
\hline \multirow{4}{*}{$\begin{array}{l}\text { Triple ( } 18 \mathrm{~W}, \\
\text { GX24q-2 Four Pin } \\
\text { Base) }\end{array}$} & 1 & $\begin{array}{l}\text { CFM } \\
18 W / G \times 24 q-2\end{array}$ & 1 & MAG STD & Mag. Stand. & 25 & 5.0" MOL \\
\hline & 2 & $\begin{array}{l}\text { CFM } \\
18 W / G \times 24 q-2\end{array}$ & 2 & MAG STD & Mag. Stand. & 50 & \\
\hline & 1 & $\begin{array}{l}\text { CFM } \\
18 W / G \times 24 q-2\end{array}$ & 1 & ELECT & Electronic & 21 & \\
\hline & 2 & $\begin{array}{l}\text { CFM } \\
18 W / G \times 24 q-2\end{array}$ & 2 & ELECT & Electronic & 38 & \\
\hline \multirow{6}{*}{$\begin{array}{l}\text { Triple ( } 26 \mathrm{~W} \text {, } \\
\text { GX24q-3 Four Pin } \\
\text { Base) }\end{array}$} & 1 & $\begin{array}{l}\text { CFIR } \\
26 W / G X 24 q-3\end{array}$ & 1 & MAG STD & Mag. Stand. & 37 & $\begin{array}{l}4.9 \text { to } 5.4^{\prime \prime} \\
\text { MOL }\end{array}$ \\
\hline & 2 & $\begin{array}{l}\text { CFIR } \\
26 W / G \times 24 q-3\end{array}$ & 2 & MAG STD & Mag. Stand. & 74 & \\
\hline & 1 & $\begin{array}{l}\text { CFIR } \\
26 W / G \times 24 q-3\end{array}$ & 1 & ELECT & Electronic & 28 & \\
\hline & 2 & $\begin{array}{l}\text { CFIR } \\
26 W / G \times 24 q-3\end{array}$ & 1 & ELECT & Electronic & 55 & \\
\hline & 1 & $\begin{array}{l}\text { CFIR } \\
26 \text { W/GX24q-3 }\end{array}$ & 1 & ELECT DIM & Electronic DImming & $8 \sim 29$ & BF .05 1.0 \\
\hline & 2 & $\begin{array}{l}\text { CFIR } \\
26 W / G \times 24 q-3\end{array}$ & 1 & ELECT DIM & Eectronic Dimming & $12 \sim 57$ & BF .05 1.0 \\
\hline \multirow{4}{*}{$\begin{array}{l}\text { Triple ( } 32 \text { W, } \\
\text { GX24q-3 Four Pin } \\
\text { Base) }\end{array}$} & 1 & $\begin{array}{l}\text { CFTR32WGX2 } \\
4 \mathrm{q}-3\end{array}$ & 1 & ELECT & Electronic & 35 & \\
\hline & 2 & $\begin{array}{l}\text { CFTR32WGX2 } \\
4 q-3\end{array}$ & 1 & ELECT & Electronic & 69 & \\
\hline & 1 & $\begin{array}{l}\text { CFTR32WGX2 } \\
4 q-3\end{array}$ & 1 & ELECT DIM & Electronic DImming & $9 \sim 38$ & BF .05 1.05 \\
\hline & 2 & $\begin{array}{l}\text { CFTR32WGX2 } \\
4 q-3\end{array}$ & 1 & ELECT DIM & Eectronic Dimming & $20 \sim 76$ & BF .05 1.05 \\
\hline
\end{tabular}

Appendix NB - Illuminance Categories and Luminaire Power 


\begin{tabular}{|c|c|c|c|c|c|c|c|}
\hline \multirow[b]{2}{*}{ Type } & \multicolumn{2}{|r|}{ Lamps } & \multicolumn{3}{|c|}{ Ballasts } & \multirow{2}{*}{$\begin{array}{l}\text { System } \\
\text { Watts }\end{array}$} & \multirow[b]{2}{*}{ Comment } \\
\hline & Number & Designation & Number & Designation & Description & & \\
\hline \multirow{4}{*}{$\begin{array}{l}\text { Triple or Quad ( } 42 W \text {, } \\
\text { GX24q-4 Four Pin } \\
\text { Base) }\end{array}$} & 1 & $\begin{array}{l}\text { CFTR42WGX2 } \\
4 q-4\end{array}$ & 1 & ELECT & Electronic & 46 & \\
\hline & 2 & $\begin{array}{l}\text { CFTR42WGX2 } \\
4 q-4\end{array}$ & 1 & ELECT & Electronic & 94 & \\
\hline & 1 & $\begin{array}{l}\text { CFTR42WGX2 } \\
4 q-4\end{array}$ & 1 & ELECT DIM & Electronic DImming & $10 \sim 49$ & BF $.05 \sim 1.05$ \\
\hline & 2 & $\begin{array}{l}\text { CFTR42WGX2 } \\
4 q-4\end{array}$ & 1 & ELECT DIM & Electronic Dimming & $20 \sim 98$ & BF $.05 \sim 1.05$ \\
\hline \multirow{2}{*}{$\begin{array}{l}\text { Triple or Quad ( } 57 \text { W, } \\
\text { GX24q-5 Four Pin } \\
\text { Base) }\end{array}$} & 1 & $\begin{array}{l}\text { CFTR57WGX2 } \\
4 q-5\end{array}$ & 1 & ELECT & Electronic & 62 & \\
\hline & 1 & $\begin{array}{l}\text { CFTR57WGX2 } \\
4 \mathrm{q}-5\end{array}$ & 1 & ELECT DIM & Electronic Dimming & $18 \sim 66$ & BF $.05 \sim 1.05$ \\
\hline \multirow{2}{*}{$\begin{array}{l}\text { Triple or Quad (70W, } \\
\text { GX24q-6 Four Pin } \\
\text { Base) }\end{array}$} & 1 & $\begin{array}{l}\text { CFTR70WGX2 } \\
4 q-6\end{array}$ & 1 & ELECT & Electronic & 75 & \\
\hline & 1 & $\begin{array}{l}\text { CFTR70WGX2 } \\
4 \mathrm{q}-6\end{array}$ & 1 & ELECT DIM & Electronic Dimming & $18 \sim 80$ & BF $.05 \sim 1.00$ \\
\hline
\end{tabular}

$\mathrm{RO}=$ ballast factor 70 to $85 \% \quad \mathrm{NO}=$ ballast factor 85 to $100 \% \quad \mathrm{HO}=$ ballast factor $>100 \%$ 
Table NB-4 -Long Compact Fluorescent

\begin{tabular}{|c|c|c|c|c|c|c|c|}
\hline \multirow[b]{2}{*}{ Type } & \multicolumn{3}{|c|}{ Lamps } & \multicolumn{2}{|c|}{ Ballasts } & \multirow{2}{*}{$\begin{array}{l}\text {-System } \\
\text { Watts }\end{array}$} & \multirow[b]{2}{*}{ Comment } \\
\hline & Number & Designation & Number & Designation & Description & & \\
\hline \multirow{6}{*}{$\begin{array}{l}\text { T5 Twin (18W - F18TT } \\
\text { Lamp) }\end{array}$} & 1 & FT18W/2G11 & 1 & MAG. & Mag. Energy Efficient & 23 & $\mathrm{BF} \sim 1.0$ \\
\hline & 2 & FT18W/2G11 & 1 & MAG. & Mag. Energy Efficient & 46 & $\mathrm{BF} \sim 1.0$ \\
\hline & 3 & FT18W/2G11 & 1 & MAG. & Mag. Energy Efficient & 69 & \\
\hline & 1 & FT18W/2G11 & 1 & ELECT & Electronic & 24 & \\
\hline & 2 & FT18W/2G11 & 1 & ELECT & Electronic & 35 & \\
\hline & 3 & FT18W/2G11 & 1 & ELECT & Electronic & 52 & \\
\hline \multirow{5}{*}{$\begin{array}{l}\text { T5 Twin (24-27W- } \\
\text { F24TT or F27TT Lamp) }\end{array}$} & 1 & FT24W/2G11 & 1 & MAG. & Mag. Energy Efficient & 32 & \\
\hline & 2 & FT24W/2G11 & 1 & MAG. & Mag. Energy Efficient & 66 & \\
\hline & 3 & FT24W/2G11 & 1 & MAG. & Mag. Energy Efficient & 98 & \\
\hline & 1 & FT24W/2G11 & 1 & ELECT & Electronic & 27 & $\mathrm{BF} \sim 1.0$ \\
\hline & 2 & FT24W/2G11 & 1 & ELECT & Electronic & 52 & $\mathrm{BF} \sim 1.0$ \\
\hline \multirow{7}{*}{$\begin{array}{l}\text { T5 Twin (36-39W - } \\
\text { F36TT or F39TT Lamp) }\end{array}$} & 1 & FT36W/2G11 & 1 & MAG. & Mag. Energy Efficient & 51 & \\
\hline & 2 & FT36W/2G11 & 1 & MAG. & Mag. Energy Efficient & 66 & \\
\hline & 3 & FT36W/2G11 & 2 & MAG. & Mag. Energy Efficient & 117 & \\
\hline & 1 & FT36W/2G11 & 1 & ELECT & Electronic & 37 & \\
\hline & 2 & FT36W/2G11 & 1 & ELECT & Electronic & 70 & \\
\hline & 1 & FT36W/2G11 & 1 & ELECTHO & Electronic High Output & 46 & $\mathrm{BF}=1.22$ \\
\hline & 2 & FT36W/2G11 & 1 & ELECTHO & Eectronic High Output & 86 & $\mathrm{BF}=1.20$ \\
\hline \multirow{3}{*}{$\begin{array}{l}\text { T5 Twin ( } 40 \text { W - F40TT } \\
\text { Lamp) }\end{array}$} & 1 & FT40W/2G11 & 1 & MAG. & Mag. Energy Efficient & 43 & \\
\hline & 2 & FT40W/2G11 & 1 & MAG. & Mag. Energy Efficient & 86 & \\
\hline & 3 & FT40W/2G11 & 2 & MAG. & Mag. Energy Efficient & 130 & \\
\hline \multirow[t]{9}{*}{ Electronic Ballasts } & 1 & FT40W/2G11 & 1 & ELECT NO & Electronic & 41 & $\mathrm{BF} \sim .90$ \\
\hline & 2 & FT40W/2G11 & 1 & ELECT NO1 & Electronic & 72 & $\mathrm{BF} \sim .88$ \\
\hline & 2 & FT40W/2G11 & 1 & ELECT NO2 & Electronic & 78 & $\mathrm{BF} \sim .97$ \\
\hline & 3 & FT40W/2G11 & 1 & ELECT NO & Electronic & 103 & $\mathrm{BF} \sim .86$ \\
\hline & 1 & FT40W/2G11 & 1 & ELECT HO & Electronic High Output & 50 & $\mathrm{BF} \sim 1.1$ \\
\hline & 1 & FT40W/2G11 & 1 & EEECT DIM1 & Electronic Dimming & $10-41$ & BF .05 1.0 \\
\hline & 2 & FT40W/2G11 & 1 & EEECT DIM1 & Electronic Dimming & $17-80$ & BF .05 1.0 \\
\hline & 1 & FT40W/2G11 & 1 & EEECT DIM2 & Electronic Dimming & $11-38$ & BF .05 .88 \\
\hline & 2 & FT40W/2G11 & 1 & ELECT DIM2 & Electronic Dimming & $16-76$ & BF .05 .88 \\
\hline \multirow[t]{5}{*}{$\begin{array}{l}\text { T5 Twin (50 W - F50TT } \\
\text { Lamp) }\end{array}$} & 1 & FT50W/2G11 & 1 & ELECT NO & $\begin{array}{l}\text { Electronic Normal } \\
\text { Output }\end{array}$ & 54 & $\mathrm{BF} \sim .98$ \\
\hline & 2 & FT50W/2G11 & 1 & ELECT NO & $\begin{array}{l}\text { Electronic Normal } \\
\text { Output }\end{array}$ & 106 & $\mathrm{BF} \sim .98$ \\
\hline & 1 & FT50W/2G11 & 1 & ELECT HO & Electronic High Output & 61 & $\mathrm{BF} \sim 1.12$ \\
\hline & 2 & FT50W/2G11 & 1 & ELECT HO & Electronic High Output & 115 & $\mathrm{BF} \sim 1.10$ \\
\hline & 1 & FT50W/2G11 & 1 & EECT DIM & Electronic Dimming & 51 & \\
\hline
\end{tabular}




\begin{tabular}{|c|c|c|c|c|c|c|c|}
\hline \multirow{3}{*}{ Type } & \multicolumn{3}{|c|}{ Lamps } & \multicolumn{2}{|c|}{ Ballasts } & \multirow{2}{*}{$\begin{array}{l}\text {-System } \\
\text { Watts }\end{array}$} & \multirow[b]{2}{*}{ Comment } \\
\hline & Number & Designation & Number & Designation & Description & & \\
\hline & 2 & FT50W/2G11 & 1 & 트ECT DIM & Electronic Dimming & 92 & \\
\hline \multirow[t]{4}{*}{$\begin{array}{l}\text { T5 Twin (55 W - F55TT } \\
\text { Lamp) }\end{array}$} & 1 & FT55W/2G11 & 1 & ELECT NO & $\begin{array}{l}\text { Electronic Normal } \\
\text { Output }\end{array}$ & 58 & $\mathrm{BF} \sim .92$ \\
\hline & 2 & FT55W/2G11 & 1 & ELECT NO & $\begin{array}{l}\text { Electronic Normal } \\
\text { Output }\end{array}$ & 109 & $\mathrm{BF} \sim .90$ \\
\hline & 1 & FT55W/2G11 & 1 & ELECT DIM & Electronic Dimming & $13-59$ & BF .03 .90 \\
\hline & 2 & FT55W/2G11 & 1 & 트ECT DIM & Electronic Dimming & $24-114$ & BF .03 .90 \\
\hline $\begin{array}{l}\text { T5 Twin (80 W- } \\
\text { F80TT Lamp) }\end{array}$ & 1 & FT80W/2G11 & 1 & ELECT NO & Electronic & 91 & $\mathrm{BF} \sim 1.00$ \\
\hline
\end{tabular}

$\mathrm{RO}=$ ballast factor 70 to $85 \% \quad \mathrm{NO}=$ ballast factor 85 to $100 \% \quad \mathrm{HO}=$ ballast factor $>100 \%$ 
Table NB-5 - Fluorescent U-Tubes

\begin{tabular}{|c|c|c|c|c|c|c|c|}
\hline \multirow[t]{2}{*}{ Type } & \multicolumn{2}{|r|}{ Lamps } & \multicolumn{3}{|c|}{ Ballasts } & \multirow{2}{*}{$\begin{array}{l}\text { System } \\
\text { Watts }\end{array}$} & \multirow[t]{2}{*}{ Comment } \\
\hline & Number & Designation & Number & Designation & Description & & \\
\hline \multirow{13}{*}{$\begin{array}{l}2 \text { ft. Fluorescent U-Tube } \\
\text { T8 (32W - FBO31T8 or } \\
\text { F32T8/U/6 Lamp) }\end{array}$} & 1 & FB31T8/F32T8U & 0.5 & MAG. & Mag. Energy Efficient & 35 & Tandem wired \\
\hline & 1 & FB31T8/F32T8U & 1 & MAG. & Mag. Energy Efficient & 36 & \\
\hline & 2 & FB31T8/F32T8U & 1 & MAG. & Mag. Energy Efficient & 69 & \\
\hline & 3 & FB31T8/F32T8U & 1.5 & MAG. & Mag. Energy Efficient & 104 & Tandem wired \\
\hline & 3 & FB31T8/F32T8U & 2 & MAG. & Mag. Energy Efficient & 105 & \\
\hline & 1 & FB31T8/F32T8U & 1 & ELECT NO & $\begin{array}{l}\text { Electronic Normal } \\
\text { Output }\end{array}$ & 39 & \\
\hline & 2 & FB31T8/F32T8U & 1 & ELECT NO & $\begin{array}{l}\text { Electronic Normal } \\
\text { Output }\end{array}$ & 62 & \\
\hline & 3 & FB31T8/F32T8U & 1 & ELECT NO & $\begin{array}{l}\text { Electronic Normal } \\
\text { Output }\end{array}$ & 92 & \\
\hline & 4 & FB31T8/F32T8U & 1 & ELECT NO & $\begin{array}{l}\text { Electronic Normal } \\
\text { Output }\end{array}$ & & \\
\hline & 1 & FB31T8/F32T8U & 1 & ELECT DIM & Electronic DImming & $9 \sim 33$ & BF $.05 \sim .88$ \\
\hline & 2 & FB31T8/F32T8U & 1 & ELECT DIM & Electronic DImming & $14 \sim 64$ & BF .05 .88 \\
\hline & 3 & FB31T8/F32T8U & 1 & ELECT DIM & Electronic Dimming & $18 \sim 93$ & BF $.05 \sim .88$ \\
\hline & 4 & FB31T8/F32T8U & 1 & ELECT DIM & Electronic Dimming & $25 \sim 116$ & BF .05 .88 \\
\hline \multirow{12}{*}{$\begin{array}{l}2 \text { ft. Fluorescent U-Tube } \\
\text { T12 ("Energy Saving" } \\
34 \mathrm{~W} \text { ) }\end{array}$} & 1 & FB40T12/ES & 0.5 & MAG. & Mag. Energy Efficient & 36 & Tandem wired \\
\hline & 1 & FB40T12/ES & 1 & MAG. & Mag. Energy Efficient & 43 & \\
\hline & 2 & FB40T12/ES & 1 & MAG. & Mag. Energy Efficient & 72 & \\
\hline & 3 & FB40T12/ES & 1 & MAG. & Mag. Energy Efficient & 105 & \\
\hline & 3 & FB40T12/ES & 1.5 & MAG. & Mag. Energy Efficient & 108 & Tandem wired \\
\hline & 3 & FB40T12/ES & 2 & MAG. & Mag. Energy Efficient & 115 & \\
\hline & 1 & FB40T12/ES & 0.5 & ELECT & Electronic & 30 & Tandem wired \\
\hline & 1 & FB40T12/ES & 1 & ELECT & Electronic & 31 & \\
\hline & 2 & FB40T12/ES & 1 & ELECT & Electronic & 59 & \\
\hline & 3 & FB40T12/ES & 1 & ELECT & Electronic & 90 & \\
\hline & 3 & FB40T12/ES & 1.5 & ELECT & Electronic & 88 & Tandem wired \\
\hline & 3 & FB40T12/ES & 2 & ELECT & Electronic & 90 & \\
\hline
\end{tabular}

$\mathrm{RO}=$ ballast factor 70 to $85 \% \quad \mathrm{NO}=$ ballast factor 85 to $100 \% \quad \mathrm{HO}=$ ballast factor $>100 \%$ 
Table NB-6 - Fluorescent Linear Lamps - Preheat

\begin{tabular}{|c|c|c|c|c|c|c|c|}
\hline \multirow[t]{2}{*}{ Type } & \multicolumn{2}{|r|}{ Lamps } & \multicolumn{3}{|c|}{ Ballasts } & \multirow{2}{*}{$\begin{array}{l}\text { System } \\
\text { Watts }\end{array}$} & \multirow[t]{2}{*}{ Comment } \\
\hline & $\mathrm{Nmbr}$ & Designation & $\mathrm{Nmbr}$ & Designation & Description & & \\
\hline $\begin{array}{l}\text { Fluorescent Preheat T5 } \\
(8 \mathrm{~W})\end{array}$ & 1 & F8T5 & 1 & MAG STD & Mag. Stand. & 12 & $12 " \mathrm{MOL}$ \\
\hline $\begin{array}{l}\text { Fluorescent Preheat T8 } \\
(15 \mathrm{~W})\end{array}$ & 1 & F15T8 & 1 & MAGSTD & Mag. Stand. & 19 & $18 " \mathrm{MOL}$ \\
\hline $\begin{array}{l}\text { Fluorescent Preheat } \\
\text { T12 }(15 \mathrm{~W})\end{array}$ & 1 & F15T12 & 1 & MAG STD & Mag. Stand. & 19 & $18^{\prime \prime} \mathrm{MOL}$ \\
\hline \multirow{2}{*}{$\begin{array}{l}\text { Fluorescent Preheat } \\
\text { T12 (20W) }\end{array}$} & 1 & F20T12 & 1 & MAG STD & Mag. Stand. & 25 & $24 " \mathrm{MOL}$ \\
\hline & 2 & F20T12 & 1 & MAG STD & Mag. Stand. & 50 & $24 " \mathrm{MOL}$ \\
\hline \multirow{2}{*}{$\begin{array}{l}\text { Fluorescent Preheat T8 } \\
(30 \mathrm{~W})\end{array}$} & 1 & F30T8 & 1 & MAG STD & Mag. Stand. & 46 & $30 " \mathrm{MOL}$ \\
\hline & 2 & F30T8 & 1 & MAG STD & Mag. Stand. & 79 & $30 " \mathrm{MOL}$ \\
\hline
\end{tabular}

$\mathrm{RO}=$ ballast factor 70 to $85 \% \quad \mathrm{NO}=$ ballast factor 85 to $100 \% \quad \mathrm{HO}=$ ballast factor $>100 \%$

Table NB-7 - Fluorescent Linear Lamps T5

\begin{tabular}{|c|c|c|c|c|c|c|}
\hline \multirow[t]{2}{*}{ Type } & \multicolumn{2}{|r|}{ Lamps } & \multicolumn{3}{|c|}{ Ballasts } & \multirow{2}{*}{$\begin{array}{l}\text { System Comment } \\
\text { - Watts }\end{array}$} \\
\hline & Number & Designation & Number & Designation & Description & \\
\hline \multirow[t]{2}{*}{$\begin{array}{l}\sim 23 " \text { Fluorescent } \\
\text { Program Start T5 }(14 W)\end{array}$} & 1 & F14T5 & 1 & ELECT & $\begin{array}{l}\text { Elect. Program Start } \\
\mathrm{BF}=1\end{array}$ & 18 \\
\hline & 2 & F14T5 & 1 & ELECT & $\begin{array}{l}\text { Elect. Program Start } \\
\mathrm{BF}=1\end{array}$ & 34 \\
\hline \multirow[t]{2}{*}{$\begin{array}{l}\sim 34.5^{\prime \prime} \text { Fluorescent } \\
\text { Program Start T5 }(21 \mathrm{~W})\end{array}$} & 1 & F21T5 & 1 & ELECT & $\begin{array}{l}\text { Elect. Program Start } \\
\mathrm{BF}=1\end{array}$ & 27 \\
\hline & 2 & F21T5 & 1 & ELECT & $\begin{array}{l}\text { Elect. Program Start } \\
\mathrm{BF}=1\end{array}$ & 50 \\
\hline \multirow[t]{2}{*}{$\begin{array}{l}\sim 46 " \text { Fluorescent } \\
\text { Program Start T5 (28W) }\end{array}$} & 1 & F28T5 & 1 & ELECT & $\begin{array}{l}\text { Elect. Program Start } \\
\mathrm{BF}=1\end{array}$ & 30 \\
\hline & 2 & F28T5 & 1 & ELECT & $\begin{array}{l}\text { Elect. Program Start } \\
\mathrm{BF}=1\end{array}$ & 60 \\
\hline \multirow[t]{2}{*}{$\begin{array}{l}\sim 58.5 \text { " Fluorescent } \\
\text { Program Start T5 }(35 \mathrm{~W})\end{array}$} & 1 & F35T5 & 1 & ELECT & $\begin{array}{l}\text { Elect. Program Start } \\
\text { BF=1 }\end{array}$ & 40 \\
\hline & 2 & F35T5 & 1 & ELECT & $\begin{array}{l}\text { Elect. Program Start } \\
\mathrm{BF}=1\end{array}$ & 78 \\
\hline \multirow{2}{*}{$\begin{array}{l}\text { 23" Fluorescent } \\
\text { Program Start T5 High } \\
\text { Output }(24 \mathrm{~W})\end{array}$} & 1 & F24T5HO & 1 & ELECT & $\begin{array}{l}\text { Elect. Program Start } \\
\mathrm{BF}=1\end{array}$ & 27 \\
\hline & 2 & $\mathrm{~F} 24 \mathrm{~T} 5 \mathrm{HO}$ & 1 & ELECT & $\begin{array}{l}\text { Elect. Program Start } \\
\mathrm{BF}=1\end{array}$ & 52 \\
\hline \multirow{2}{*}{$\begin{array}{l}\sim 34.5^{\prime \prime} \text { Fluorescent } \\
\text { Program Start T5 High } \\
\text { Output(39W) }\end{array}$} & 1 & F39T5 & 1 & ELECT & $\begin{array}{l}\text { Elect. Program Start } \\
\mathrm{BF}=1\end{array}$ & 43 \\
\hline & 2 & F39T5 & 1 & ELECT & $\begin{array}{l}\text { Elect. Program Start } \\
\mathrm{BF}=1\end{array}$ & 85 \\
\hline \multirow{2}{*}{$\begin{array}{l}\sim 46^{\prime \prime} \text { Fluorescent } \\
\text { Program Start T5 High } \\
\text { Output (54W) }\end{array}$} & 1 & F54T5 & 1 & ELECT & $\begin{array}{l}\text { Elect. Program Start } \\
\mathrm{BF}=1\end{array}$ & 62 \\
\hline & 2 & F54T5 & 1 & ELECT & $\begin{array}{l}\text { Elect. Program Start } \\
\mathrm{BF}=1\end{array}$ & 117 \\
\hline
\end{tabular}




\begin{tabular}{|c|c|c|c|c|c|c|}
\hline & 1 & F54T5 & 1 & ELECT DIM & Elect. Dimming & $12-63$ \\
\hline & 2 & F54T5 & 1 & ELECT DIM & Elect. Dimming & $24-125$ \\
\hline $\begin{array}{l}\sim 57.5^{\prime \prime} \text { Fluorescent } \\
\text { Program Start T5 High } \\
\text { Output }(80 \mathrm{~W})\end{array}$ & 1 & ${ }^{\circ} \mathrm{F} 80 \mathrm{T5}$ & 1 & ELECT & $\begin{array}{l}\text { Elect. Program Start } \\
\mathrm{BF}=1\end{array}$ & 89 \\
\hline
\end{tabular}


Table NB-8 - Fluorescent Rapid Start T-8

\begin{tabular}{|c|c|c|c|c|c|c|c|}
\hline \multirow[t]{2}{*}{ Type } & \multicolumn{2}{|r|}{ Lamps } & \multicolumn{3}{|c|}{ Ballasts } & \multirow{2}{*}{$\begin{array}{l}\text { System } \\
\text { Watts }\end{array}$} & \multirow[t]{2}{*}{ Comment } \\
\hline & Number & Designation & Number & Designation & Description & & \\
\hline \multirow{2}{*}{$\begin{array}{l}2 \text { foot Fluorescent } \\
\text { Rapid Start T8 (17W) }\end{array}$} & 1 & F17T8 & 1 & MAG. & Mag. Energy Efficient & 24 & \\
\hline & 2 & F17T8 & 1 & MAG. & Mag. Energy Efficient & 45 & \\
\hline \multirow[t]{5}{*}{ Electronic Ballasts } & 1 & F17T8 & 1 & ELECT NO & $\begin{array}{l}\text { Electronic Normal } \\
\text { Output }\end{array}$ & 22 & \\
\hline & 2 & F17T8 & 1 & ELECT NO & $\begin{array}{l}\text { Electronic Normal } \\
\text { Output }\end{array}$ & 33 & \\
\hline & 3 & F17T8 & 1 & ELECT NO & $\begin{array}{l}\text { Electronic Normal } \\
\text { Output }\end{array}$ & 53 & \\
\hline & 3 & F17T8 & 2 & ELECT NO & $\begin{array}{l}\text { Electronic Normal } \\
\text { Output }\end{array}$ & 55 & \\
\hline & 4 & F17T8 & 1 & ELECT NO & $\begin{array}{l}\text { Electronic Normal } \\
\text { Output }\end{array}$ & 63 & \\
\hline \multirow{4}{*}{$\begin{array}{l}2 \text { foot Fluorescent } \\
\text { Rapid Start T8 (17W) }\end{array}$} & 1 & F17T8 & 1 & ELECT DIM & Electronic Dimming & $8 \sim 20$ & $\mathrm{BF} .05 \sim .88$ \\
\hline & 2 & F17T8 & 1 & ELECT DIM & Electronic Dimming & $10 \sim 37$ & BF .05 . .88 \\
\hline & 3 & F17T8 & 1 & ELECT DIM & Electronic Dimming & $12 \sim 56$ & BF .05 . .88 \\
\hline & 4 & F17T8 & 1 & ELECT DIM & Electronic Dimming & $18 \sim 69$ & BF .05 . .88 \\
\hline \multirow{2}{*}{$\begin{array}{l}3 \text { foot Fluorescent } \\
\text { Rapid Start T8 (25W) }\end{array}$} & 1 & $\mathrm{~F} 25 \mathrm{~T} 8$ & 1 & MAG. & Mag. Energy Efficient & 33 & \\
\hline & 2 & $\mathrm{~F} 25 \mathrm{~T} 8$ & 1 & MAG. & Mag. Energy Efficient & 65 & \\
\hline \multirow[t]{14}{*}{ Electronic Ballasts } & 1 & F25T8 & 1 & ELECT NO & $\begin{array}{l}\text { Electronic Normal } \\
\text { Output }\end{array}$ & 27 & \\
\hline & 2 & F25T8 & 1 & ELECT NO & $\begin{array}{l}\text { Electronic Normal } \\
\text { Output }\end{array}$ & 48 & \\
\hline & 3 & $\mathrm{~F} 25 \mathrm{~T} 8$ & 1 & ELECT NO & $\begin{array}{l}\text { Electronic Normal } \\
\text { Output }\end{array}$ & 68 & \\
\hline & 4 & F25T8 & 1 & ELECT NO & $\begin{array}{l}\text { Electronic Normal } \\
\text { Output }\end{array}$ & 89 & \\
\hline & 1 & $\mathrm{~F} 25 \mathrm{~T} 8$ & 1 & ELECT RO & $\begin{array}{l}\text { Electronic Reduced } \\
\text { Output }\end{array}$ & 24 & \\
\hline & 2 & F25T8 & 1 & ELECT RO & $\begin{array}{l}\text { Electronic Reduced } \\
\text { Output }\end{array}$ & 41 & \\
\hline & 3 & $\mathrm{~F} 25 \mathrm{~T} 8$ & 1 & ELECT RO & $\begin{array}{l}\text { Electronic Reduced } \\
\text { Output }\end{array}$ & 59 & \\
\hline & 4 & $\mathrm{~F} 25 \mathrm{~T} 8$ & 1 & ELECT RO & $\begin{array}{l}\text { Electronic Reduced } \\
\text { Output }\end{array}$ & 76 & \\
\hline & 1 & F25T8 & 1 & ELECT HO & Electronic High Output & 29 & $\mathrm{BF} \sim 1.05$ \\
\hline & 2 & F25T8 & 1 & ELECT HO & Electronic High Output & 51 & $\mathrm{BF} \sim 1.05$ \\
\hline & 3 & $\mathrm{~F} 25 \mathrm{~T} 8$ & 1 & ELECT HO & Electronic High Output & 74 & $\mathrm{BF} \sim 1.05$ \\
\hline & 1 & $\mathrm{~F} 25 \mathrm{~T} 8$ & 1 & ELECT DIM & Electronic Dimming & $8 \sim 25$ & BF .05 .94 \\
\hline & 2 & F25T8 & 1 & ELECT DIM & Electronic Dimming & $13 \sim 49$ & BF .05 .94 \\
\hline & 3 & $\mathrm{~F} 25 \mathrm{~T} 8$ & 1 & ELECT DIM & Electronic Dimming & $16 \sim 76$ & BF .05 .94 \\
\hline
\end{tabular}




\begin{tabular}{|c|c|c|c|c|c|c|c|}
\hline \multirow[t]{3}{*}{ Type } & \multicolumn{2}{|r|}{ Lamps } & \multicolumn{3}{|c|}{ Ballasts } & \multirow{2}{*}{$\begin{array}{l}\text { System } \\
\text { Watts }\end{array}$} & \multirow[t]{2}{*}{ Comment } \\
\hline & Number & Designation & Number & Designation & Description & & \\
\hline & 4 & $\mathrm{~F} 25 \mathrm{~T} 8$ & 1 & ELECT DIM & Electronic Dimming & $22 \sim 96$ & BF $.05 \sim .88$ \\
\hline \multirow{4}{*}{$\begin{array}{l}4 \text { foot Fluorescent } \\
\text { Rapid Start T12 for T- } 8 \\
\text { ballasts ("Energy } \\
\text { Saving" } 25 \mathrm{~W} \text { ) }\end{array}$} & 1 & F25T12ES & 1 & ELECT NO & $\begin{array}{l}\text { Electronic Normal } \\
\text { Output }\end{array}$ & 27 & \\
\hline & 2 & F25T12ES & 1 & ELECT NO & $\begin{array}{l}\text { Electronic Normal } \\
\text { Output }\end{array}$ & 52 & \\
\hline & 3 & F25T12ES & 1 & ELECT NO & $\begin{array}{l}\text { Electronic Normal } \\
\text { Output }\end{array}$ & 77 & \\
\hline & 4 & F25T12ES & 1 & ELECT NO & $\begin{array}{l}\text { Electronic Normal } \\
\text { Output }\end{array}$ & 95 & \\
\hline \multirow{16}{*}{$\begin{array}{l}4 \text { foot Fluorescent } \\
\text { Instant Start T8 } \\
\text { ("Energy Saving" 30W) }\end{array}$} & 1 & F32T8/30ES & 1 & ELECT NO & $\begin{array}{l}\text { Electronic Normal } \\
\text { Output }\end{array}$ & 29 & \\
\hline & 2 & F32T8/30ES & 1 & EECT NO & $\begin{array}{l}\text { Electronic Normal } \\
\text { Output }\end{array}$ & 54 & \\
\hline & 3 & F32T8/30ES & 1 & ELECT NO & $\begin{array}{l}\text { Electronic Normal } \\
\text { Output }\end{array}$ & 79 & \\
\hline & 4 & F32T8/30ES & 1 & ELECT NO & $\begin{array}{l}\text { Electronic Normal } \\
\text { Output }\end{array}$ & 104 & \\
\hline & 1 & F32T8/30ES & 1 & ELECT RO & $\begin{array}{l}\text { Electronic Reduced } \\
\text { Output }\end{array}$ & 27 & \\
\hline & 2 & F32T8/30ES & 1 & ELECT RO & $\begin{array}{l}\text { Electronic Reduced } \\
\text { Output }\end{array}$ & 48 & \\
\hline & 3 & F32T8/30ES & 1 & ELECT RO & $\begin{array}{l}\text { Electronic Reduced } \\
\text { Output }\end{array}$ & 70 & \\
\hline & 4 & F32T8/30ES & 1 & ELECT RO & $\begin{array}{l}\text { Electronic Reduced } \\
\text { Output }\end{array}$ & 91 & \\
\hline & 1 & F32T8/30ES & 1 & $\begin{array}{l}\text { ELECT NO } \\
\text { EE }\end{array}$ & EE Normal Output & 33 & \\
\hline & 2 & F32T8/30ES & 1 & $\begin{array}{l}\text { ELECT NO } \\
\text { EE }\end{array}$ & $\begin{array}{l}\text { Energy efficiency } \\
\text { Normal Output }\end{array}$ & 52 & \\
\hline & 3 & F32T8/30ES & 1 & $\begin{array}{l}\text { ELECT NO } \\
\text { EE }\end{array}$ & $\begin{array}{l}\text { Energy efficiency } \\
\text { Normal Output }\end{array}$ & 77 & \\
\hline & 4 & F32T8/30ES & 1 & $\begin{array}{l}\text { ELECT NO } \\
\text { EE }\end{array}$ & $\begin{array}{l}\text { Energy efficiency } \\
\text { Normal Output }\end{array}$ & 101 & \\
\hline & 1 & F32T8/30ES & 1 & $\begin{array}{l}\text { ELECT RO } \\
\text { EE }\end{array}$ & EE Reduced Output & 28 & \\
\hline & 2 & F32T $8 / 30 \mathrm{ES}$ & 1 & $\begin{array}{l}\text { ELECT RO } \\
\text { EE }\end{array}$ & EE Reduced Output & 45 & \\
\hline & 3 & F32T8/30ES & 1 & $\begin{array}{l}\text { ELECT RO } \\
\text { EE }\end{array}$ & EE Reduced Output & 66 & \\
\hline & 4 & F32T8/30ES & 1 & $\begin{array}{l}\text { ELECT RO } \\
\text { EE }\end{array}$ & EE Reduced Output & 88 & \\
\hline \multirow[t]{3}{*}{$\begin{array}{l}4 \text { foot Fluorescent } \\
\text { Rapid Start T8 (32W) }\end{array}$} & 1 & F32T8 & 0.5 & MAG. & Mag. Energy Efficient & 35 & $\begin{array}{l}\text { Tandem } \\
\text { wired }\end{array}$ \\
\hline & 1 & F32T8 & 1 & MAG. & Mag. Energy Efficient & 39 & \\
\hline & 2 & F32T8 & 1 & MAG. & Mag. Energy Efficient & 70 & \\
\hline
\end{tabular}




\begin{tabular}{|c|c|c|c|c|c|c|c|}
\hline \multirow[t]{5}{*}{ Type } & \multicolumn{2}{|r|}{ Lamps } & \multicolumn{3}{|c|}{ Ballasts } & \multirow{2}{*}{$\begin{array}{l}\text { System } \\
\text { Watts }\end{array}$} & \multirow[t]{2}{*}{ Comment } \\
\hline & Number & Designation & Number & Designation & Description & & \\
\hline & 3 & F32T8 & 1.5 & MAG. & Mag. Energy Efficient & 105 & $\begin{array}{l}\text { Tandem } \\
\text { wired }\end{array}$ \\
\hline & 3 & F32T8 & 2 & MAG. & Mag. Energy Efficient & 109 & \\
\hline & 4 & F32T8 & 2 & MAG. & Mag. Energy Efficient & 140 & $\begin{array}{l}(2) \text { two-lamp } \\
\text { ballasts }\end{array}$ \\
\hline \multirow[t]{26}{*}{$\begin{array}{l}4 \text { foot Fluorescent } \\
\text { Rapid Start T8 (32W) }\end{array}$} & 1 & $\mathrm{~F} 32 \mathrm{~T} 8$ & 1 & ELECT NO & $\begin{array}{l}\text { Electronic Normal } \\
\text { Output }\end{array}$ & 32 & \\
\hline & 2 & F32T8 & 1 & ELECT NO & $\begin{array}{l}\text { Electronic Normal } \\
\text { Output }\end{array}$ & 62 & \\
\hline & 3 & F32T8 & 1 & ELECT NO & $\begin{array}{l}\text { Electronic Normal } \\
\text { Output }\end{array}$ & 93 & \\
\hline & 4 & F32T8 & 1 & ELECT NO & $\begin{array}{l}\text { Electronic Normal } \\
\text { Output }\end{array}$ & 114 & \\
\hline & 1 & F32T8 & 1 & EENO & EE Normal Output & 35 & \\
\hline & 2 & F32T8 & 1 & EENO & EE Normal Output & 55 & \\
\hline & 3 & F32T8 & 1 & EENO & EE Normal Output & 82 & \\
\hline & 4 & F32T8 & 1 & EENO & EE Normal Output & 107 & \\
\hline & 1 & F32T8 & 1 & ELECT RO & $\begin{array}{l}\text { Electronic Reduced } \\
\text { Output }\end{array}$ & 29 & \\
\hline & 2 & $\mathrm{~F} 32 \mathrm{~T} 8$ & 1 & ELECT RO & $\begin{array}{l}\text { Electronic Reduced } \\
\text { Output }\end{array}$ & 51 & \\
\hline & 3 & $\mathrm{~F} 32 \mathrm{~T} 8$ & 1 & ELECT RO & $\begin{array}{l}\text { Electronic Reduced } \\
\text { Output }\end{array}$ & 76 & \\
\hline & 4 & F32T8 & 1 & ELECT RO & $\begin{array}{l}\text { Electronic Reduced } \\
\text { Output }\end{array}$ & 98 & \\
\hline & 2 & F32T8 & 1 & ELECT HO & Electronic High Output & 77 & $\mathrm{BF} \sim 1.13$ \\
\hline & 3 & F32T8 & 1 & ELECT HO & Electronic High Output & 112 & $\mathrm{BF} \sim 1.18$ \\
\hline & 1 & F32T8 & 1 & EE RO & EE Reduced Output & 30 & \\
\hline & 2 & F32T8 & 1 & EE RO & EE Reduced Output & 48 & \\
\hline & 3 & F32T8 & 1 & EE RO & EE Reduced Output & 73 & \\
\hline & 4 & F32T8 & 1 & EE RO & EE Reduced Output & 96 & \\
\hline & 2 & F32T8 & 1 & ELECT TL & $\begin{array}{l}\text { Electronic Two Level } \\
(50 \& 100 \%)\end{array}$ & 65 & \\
\hline & 1 & F32T8 & 1 & ELECT DIM1 & Electronic Dimming & $9 \sim 35$ & BF $.05 \sim 1.0$ \\
\hline & 2 & $\mathrm{~F} 32 \mathrm{~T} 8$ & 1 & ELECT DIM1 & Electronic Dimming & $15 \sim 68$ & BF $.05 \sim 1.0$ \\
\hline & 3 & F32T8 & 1 & ELECT DIM1 & Electronic Dimming & $20 \sim 102$ & BF $.05 \sim 1.0$ \\
\hline & 1 & F32T8 & 1 & ELECT DIMR & Eectronic Dimming & $9 \sim 33$ & BF .05 .88 \\
\hline & 2 & $\mathrm{~F} 32 \mathrm{~T} 8$ & 1 & ELECT DIMR & Electronic Dimming & $14 \sim 64$ & BF .05 .88 \\
\hline & 3 & F32T8 & 1 & ELECT DIM2 & Electronic Dimming & $18 \sim 93$ & BF $.05 \sim .88$ \\
\hline & 4 & F32T8 & 1 & ELECT DIM2 & Electronic Dimming & $25 \sim 116$ & BF .05 .88 \\
\hline 5 foot Fluorescent & 1 & F40T8 & 1 & MAG. & Mag. Energy Efficient & 50 & \\
\hline
\end{tabular}




\begin{tabular}{|c|c|c|c|c|c|c|c|}
\hline \multirow{6}{*}{$\begin{array}{l}\text { Type } \\
\text { Rapid Start T8 (40W) }\end{array}$} & \multicolumn{2}{|r|}{ Lamps } & \multicolumn{3}{|c|}{ Ballasts } & \multirow{2}{*}{$\begin{array}{l}\text { System } \\
\text { Watts }\end{array}$} & \multirow[t]{2}{*}{ Comment } \\
\hline & Number & Designation & Number & Designation & Description & & \\
\hline & 2 & F40T8 & 1 & MAG. & Mag. Energy Efficient & 92 & \\
\hline & 1 & F40T8 & 1 & ELECT & Electronic & 46 & \\
\hline & 2 & F40T8 & 1 & ELECT & Electronic & 79 & \\
\hline & 3 & F40T8 & 1 & ELECT & Electronic & 112 & \\
\hline \multirow{7}{*}{$\begin{array}{l}3 \text { foot Fluorescent } \\
\text { Rapid Start T12 } \\
\text { ("Energy-Saving" 25W) }\end{array}$} & 1 & F30T12/ES & 1 & MAG STD & Mag. Stand. & 42 & \\
\hline & 2 & F30T12/ES & 1 & MAG STD & Mag. Stand. & 74 & \\
\hline & 3 & F30T12/ES & 1.5 & MAG STD & Mag. Stand. & 111 & $\begin{array}{l}\text { Tandem } \\
\text { wired }\end{array}$ \\
\hline & 3 & F30T12/ES & 2 & MAG STD & Mag. Stand. & 116 & \\
\hline & 2 & F30T12/ES & 1 & MAG. & Mag. Energy Efficient & 66 & \\
\hline & 1 & F30T12/ES & 1 & ELECT & Electronic & 26 & \\
\hline & 2 & F30T12/ES & 1 & ELECT & Electronic & 53 & \\
\hline \multirow{7}{*}{$\begin{array}{l}3 \text { foot Fluorescent } \\
\text { Rapid Start T12 } \\
\text { ("Stand." 30W) }\end{array}$} & 1 & F30T12 & 1 & MAG STD & Mag. Stand. & 46 & \\
\hline & 2 & F30T12 & 1 & MAG STD & Mag. Stand. & 79 & \\
\hline & 3 & F30T12 & 1.5 & MAG STD & Mag. Stand. & 118 & $\begin{array}{l}\text { Tandem } \\
\text { wired }\end{array}$ \\
\hline & 3 & F30T12 & 2 & MAG STD & Mag. Stand. & 125 & \\
\hline & 2 & F30T12 & 1 & MAG. & Mag. Energy Efficient & 73 & \\
\hline & 1 & F30T12 & 1 & ELECT & Electronic & 30 & \\
\hline & 2 & F30T12 & 1 & ELECT & Electronic & 60 & \\
\hline \multirow{7}{*}{$\begin{array}{l}4 \text { foot Fluorescent } \\
\text { Rapid Start T12 } \\
\text { ("Energy-Saving } \\
\text { Plus"32W) }\end{array}$} & 1 & F40T12/ES Plus & 0.5 & MAG. & Mag. Energy Efficient & 34 & $\begin{array}{l}\text { Tandem } \\
\text { wired }\end{array}$ \\
\hline & 1 & F40T12/ES Plus & 1 & MAG. & Mag. Energy Efficient & 41 & \\
\hline & 2 & F40T12/ES Plus & 1 & MAG. & Mag. Energy Efficient & 68 & \\
\hline & 3 & F40T12/ES Plus & 1 & MAG. & Mag. Energy Efficient & 99 & \\
\hline & 3 & F40T12/ES Plus & 1.5 & MAG. & Mag. Energy Efficient & 102 & $\begin{array}{l}\text { Tandem } \\
\text { wired }\end{array}$ \\
\hline & 3 & F40T12/ES Plus & 2 & MAG. & Mag. Energy Efficient & 109 & \\
\hline & 4 & F40T12/ES Plus & 2 & MAG. & Mag. Energy Efficient & 136 & $\begin{array}{l}\text { (2) Two-lamp } \\
\text { ballasts }\end{array}$ \\
\hline
\end{tabular}

$\mathrm{RO}=$ ballast factor 70 to $85 \% \quad \mathrm{NO}=$ ballast factor 85 to $100 \% \quad \mathrm{HO}=$ ballast factor $>100 \%$ 
Table NB-9 - Fluorescent Rapid Start T-12

\begin{tabular}{|c|c|c|c|c|c|c|c|}
\hline \multirow[t]{2}{*}{ Type } & \multicolumn{2}{|r|}{ Lamps } & \multicolumn{3}{|c|}{ Ballasts } & \multirow{2}{*}{$\begin{array}{l}\text { System } \\
\text { Watts }\end{array}$} & \multirow[t]{2}{*}{ Comment } \\
\hline & Number & Designation & Number & Designation & Description & & \\
\hline \multirow{27}{*}{$\begin{array}{l}4 \text { foot Fluorescent } \\
\text { Rapid Start T12 } \\
\text { ("Energy-Saving"34W) }\end{array}$} & 1 & F40T12/ES & 0.5 & MAG STD ${ }^{\star \star}$ & Mag. Stand. & 42 & $\begin{array}{l}\text { Tandem } \\
\text { wired }\end{array}$ \\
\hline & 1 & F40T12/ES & 1 & MAG STD** & Mag. Stand. & 48 & \\
\hline & 2 & F40T12/ES & 1 & MAG STD** & Mag. Stand. & 82 & \\
\hline & 3 & F40T12/ES & 1.5 & MAG STD** & Mag. Stand. & 122 & $\begin{array}{l}\text { Tandem } \\
\text { wired }\end{array}$ \\
\hline & 3 & F40T12/ES & 2 & MAG STD ${ }^{\star *}$ & Mag. Stand. & 130 & \\
\hline & 4 & F40T12/ES & 2 & MAG STD ${ }^{\star \star}$ & Mag. Stand. & 164 & $\begin{array}{l}\text { (2) Two-lamp } \\
\text { ballasts }\end{array}$ \\
\hline & 1 & F40T12/ES & 0.5 & MAG. & Mag. Energy Efficient & 36 & $\begin{array}{l}\text { Tandem } \\
\text { wired }\end{array}$ \\
\hline & 1 & F40T12/ES & 1 & MAG. & Mag. Energy Efficient & 43 & \\
\hline & 2 & F40T12/ES & 1 & MAG. & Mag. Energy Efficient & 72 & \\
\hline & 3 & F40T12/ES & 1 & MAG. & Mag. Energy Efficient & 105 & \\
\hline & 3 & F40T12/ES & 1.5 & MAG. & Mag. Energy Efficient & 108 & $\begin{array}{l}\text { Tandem } \\
\text { wired }\end{array}$ \\
\hline & 3 & F40T12/ES & 2 & MAG. & Mag. Energy Efficient & 112 & \\
\hline & 4 & F40T12/ES & 2 & MAG. & Mag. Energy Efficient & 144 & $\begin{array}{l}\text { (2) Two-lamp } \\
\text { ballasts }\end{array}$ \\
\hline & 2 & F40T12/ES & 1 & MAG HC & Mag. Heater Cutout & 58 & \\
\hline & 3 & F40T12/ES & 1.5 & MAG HC & Mag. Heater Cutout & 87 & $\begin{array}{l}\text { Tandem } \\
\text { wired }\end{array}$ \\
\hline & 4 & F40T12/ES & 2 & MAG HC & Mag. Heater Cutout & 116 & $\begin{array}{l}\text { (2) Two-lamp } \\
\text { ballasts }\end{array}$ \\
\hline & 2 & F40T12/ES & 1 & MAG HC FO & $\begin{array}{l}\text { Mag. Heater Cutout } \\
\text { Full Light }\end{array}$ & 66 & \\
\hline & 3 & F40T12/ES & 1.5 & MAG HC FO & $\begin{array}{l}\text { Mag. Heater Cutout } \\
\text { Full Light }\end{array}$ & 99 & $\begin{array}{l}\text { Tandem } \\
\text { wired }\end{array}$ \\
\hline & 4 & F40T12/ES & 2 & MAG HC FO & $\begin{array}{l}\text { Mag. Heater Cutout } \\
\text { Full Light }\end{array}$ & 132 & $\begin{array}{l}\text { (2) Two-lamp } \\
\text { ballasts }\end{array}$ \\
\hline & 1 & F40T12/ES & 0.5 & ELECT & Electronic & 30 & $\begin{array}{l}\text { Tandem } \\
\text { wired }\end{array}$ \\
\hline & 1 & F40T12/ES & 1 & ELECT & Electronic & 31 & \\
\hline & 2 & F40T12/ES & 1 & ELECT & Electronic & 62 & \\
\hline & 3 & F40T12/ES & 1 & ELECT & Electronic & 90 & \\
\hline & 3 & F40T12/ES & 1.5 & ELECT & Electronic & 93 & $\begin{array}{l}\text { Tandem } \\
\text { wired }\end{array}$ \\
\hline & 3 & F40T12/ES & 2 & ELECT & Electronic & 93 & \\
\hline & 4 & F40T12/ES & 1 & ELECT & Electronic & 121 & \\
\hline & 4 & F40T12/ES & 2 & ELECT & Electronic & 124 & $\begin{array}{l}\text { (2) Two-lamp } \\
\text { ballasts }\end{array}$ \\
\hline
\end{tabular}




\begin{tabular}{|c|c|c|c|c|c|c|c|}
\hline \multirow[t]{5}{*}{ Type } & \multicolumn{2}{|r|}{ Lamps } & \multicolumn{3}{|c|}{ Ballasts } & \multirow{2}{*}{$\begin{array}{l}\text { System } \\
\text { Watts }\end{array}$} & \multirow[t]{2}{*}{ Comment } \\
\hline & Number & Designation & Number & Designation & Description & & \\
\hline & 2 & F40T12/ES & 1 & ELECT AO & $\begin{array}{l}\text { Elec. Adjustable } \\
\text { Output (to 15\%) }\end{array}$ & 60 & \\
\hline & 3 & F40T12/ES & 1.5 & ELECT AO & $\begin{array}{l}\text { Elec. Adjustable } \\
\text { Output (to } 15 \% \text { ) }\end{array}$ & 90 & $\begin{array}{l}\text { Tandem } \\
\text { wired }\end{array}$ \\
\hline & 4 & F40T12/ES & 2 & ELECT AO & $\begin{array}{l}\text { Elec. Adjustable } \\
\text { Output (to } 15 \% \text { ) }\end{array}$ & 120 & $\begin{array}{l}\text { (2) Two-lamp } \\
\text { ballasts }\end{array}$ \\
\hline \multirow{10}{*}{$\begin{array}{l}4 \text { foot Fluorescent } \\
\text { Rapid Start Stand. } \\
(40 \mathrm{~W})\end{array}$} & 1 & F40T12 & 0.5 & MAG. & Mag. Energy Efficient & 44 & $\begin{array}{l}\text { Tandem } \\
\text { wired }\end{array}$ \\
\hline & 1 & F40T12 & 1 & MAG. & Mag. Energy Efficient & 46 & \\
\hline & 2 & F40T12 & 1 & MAG. & Mag. Energy Efficient & 88 & \\
\hline & 3 & F40T12 & 1 & MAG. & Mag. Energy Efficient & 127 & \\
\hline & 3 & F40T12 & 1.5 & MAG. & Mag. Energy Efficient & 132 & $\begin{array}{l}\text { Tandem } \\
\text { wired }\end{array}$ \\
\hline & 3 & F40T12 & 2 & MAG. & Mag. Energy Efficient & 134 & \\
\hline & 4 & F40T12 & 2 & MAG. & Mag. Energy Efficient & 176 & $\begin{array}{l}\text { (2) Two-lamp } \\
\text { ballasts }\end{array}$ \\
\hline & 2 & F40T12 & 1 & MAG HC & Mag. Heater Cutout & 71 & \\
\hline & 3 & F40T12 & 1.5 & MAG HC & Mag. Heater Cutout & 107 & $\begin{array}{l}\text { Tandem } \\
\text { wired }\end{array}$ \\
\hline & 4 & F40T12 & 2 & MAG HC & Mag. Heater Cutout & 142 & $\begin{array}{l}\text { (2) Two-lamp } \\
\text { ballasts }\end{array}$ \\
\hline \multirow{13}{*}{$\begin{array}{l}4 \text { foot Fluorescent } \\
\text { Rapid Start Stand. } \\
(40 \mathrm{~W}) \text { cont. }\end{array}$} & 2 & ${ }^{\circ} \mathrm{F} 40 \mathrm{~T} 12$ & 1 & $\mathrm{MAG}^{\circ} \mathrm{F} F \mathrm{~F}$ & $\begin{array}{l}\text { Mag. Heater Cutout } \\
\text { Full Light }\end{array}$ & 80 & \\
\hline & 3 & ${ }^{\circ} \mathrm{F} 40 \mathrm{~T} 12$ & 1.5 & $M A G^{\circ} \mathrm{F} F O$ & $\begin{array}{l}\text { Mag. Heater Cutout } \\
\text { Full Light }\end{array}$ & 120 & $\begin{array}{l}\text { Tandem } \\
\text { wired }\end{array}$ \\
\hline & 4 & ${ }^{\circ} \mathrm{F} 40 \mathrm{~T} 12$ & 2 & $M A G^{\circ} \mathrm{F} F O$ & $\begin{array}{l}\text { Mag. Heater Cutout } \\
\text { Full Light }\end{array}$ & 160 & $\begin{array}{l}\text { (2) Two-lamp } \\
\text { ballasts }\end{array}$ \\
\hline & 1 & ${ }^{\circ} \mathrm{F} 40 \mathrm{~T} 12$ & 0.5 & ELECT & Electronic & 36 & $\begin{array}{l}\text { Tandem } \\
\text { wired }\end{array}$ \\
\hline & 1 & ${ }^{\circ} \mathrm{F} 40 \mathrm{~T} 12$ & 1 & ELECT & Electronic & 37 & \\
\hline & 2 & ${ }^{\circ} \mathrm{F} 40 \mathrm{~T} 12$ & 1 & ELECT & Electronic & 72 & \\
\hline & 3 & ${ }^{\circ} \mathrm{F} 40 \mathrm{~T} 12$ & 1 & ELECT & Electronic & 107 & \\
\hline & 3 & ${ }^{\circ} \mathrm{F} 40 \mathrm{~T} 12$ & 1.5 & ELECT & Electronic & 108 & $\begin{array}{l}\text { Tandem } \\
\text { wired }\end{array}$ \\
\hline & 3 & ${ }^{\circ} \mathrm{F} 40 \mathrm{~T} 12$ & 2 & ELECT & Electronic & 109 & \\
\hline & 4 & ${ }^{\circ} \mathrm{F} 40 \mathrm{~T} 12$ & 1 & ELECT & Electronic & 135 & \\
\hline & 4 & ${ }^{\circ} \mathrm{F} 40 \mathrm{~T} 12$ & 2 & ELECT & Electronic & 144 & $\begin{array}{l}\text { (2) Two-lamp } \\
\text { ballasts }\end{array}$ \\
\hline & 2 & ${ }^{\circ} \mathrm{F} 40 \mathrm{~T} 12$ & 1 & ELECT RO & $\begin{array}{l}\text { Electronic Reduce } \\
\text { Output }(75 \%)\end{array}$ & 61 & \\
\hline & 3 & ${ }^{\circ} \mathrm{F} 40 \mathrm{~T} 12$ & 1 & ELECT RO & $\begin{array}{l}\text { Electronic Reduce } \\
\text { Output }(75 \%)\end{array}$ & 90 & \\
\hline
\end{tabular}




\begin{tabular}{|c|c|c|c|c|c|c|c|}
\hline \multirow[t]{2}{*}{ Type } & \multicolumn{2}{|r|}{ Lamps } & \multicolumn{3}{|c|}{ Ballasts } & \multirow{2}{*}{$\begin{array}{l}\text { System } \\
\text { Watts }\end{array}$} & \multirow[t]{2}{*}{ Comment } \\
\hline & Number & Designation & Number & Designation & Description & & \\
\hline & 3 & ${ }^{\circ} \mathrm{F} 40 \mathrm{~T} 12$ & 1.5 & ELECT RO & $\begin{array}{l}\text { Electronic Reduce } \\
\text { Output }(75 \%)\end{array}$ & 92 & $\begin{array}{l}\text { Tandem } \\
\text { wired }\end{array}$ \\
\hline & 4 & ${ }^{\circ} \mathrm{F} 40 \mathrm{~T} 12$ & 2 & ELECT RO & $\begin{array}{l}\text { Electronic Reduce } \\
\text { Output }(75 \%)\end{array}$ & 122 & $\begin{array}{l}\text { (2) Two-lam } \\
\text { ballasts }\end{array}$ \\
\hline & 2 & ${ }^{\circ} \mathrm{F} 40 \mathrm{~T} 12$ & 1 & ELECT TL & $\begin{array}{l}\text { Elec. Two Level (50 \& } \\
100 \%)\end{array}$ & 69 & \\
\hline & 3 & ${ }^{\circ} \mathrm{F} 40 \mathrm{~T} 12$ & 1.5 & ELECT TL & $\begin{array}{l}\text { Elec. Two Level (50 \& } \\
100 \%)\end{array}$ & 104 & $\begin{array}{l}\text { Tandem } \\
\text { wired }\end{array}$ \\
\hline & 4 & ${ }^{\circ} \mathrm{F} 40 \mathrm{~T} 12$ & 2 & ELECT TL & $\begin{array}{l}\text { Elec. Two Level (50 \& } \\
100 \%)\end{array}$ & 138 & $\begin{array}{l}\text { (2) Two-lam } \\
\text { ballasts }\end{array}$ \\
\hline & 2 & ${ }^{\circ} \mathrm{F} 40 \mathrm{~T} 12$ & 1 & ELECT AO & $\begin{array}{l}\text { Elec. Adjustable } \\
\text { Output (to } 15 \% \text { ) }\end{array}$ & 73 & \\
\hline & 3 & ${ }^{\circ} \mathrm{F} 40 \mathrm{~T} 12$ & 1.5 & ELECT AO & $\begin{array}{l}\text { Elec. Adjustable } \\
\text { Output (to } 15 \% \text { ) }\end{array}$ & 110 & $\begin{array}{l}\text { Tandem } \\
\text { wired }\end{array}$ \\
\hline & 4 & ${ }^{\circ} \mathrm{F} 40 \mathrm{~T} 12$ & 2 & ELECT AO & $\begin{array}{l}\text { Elec. Adjustable } \\
\text { Output (to } 15 \% \text { ) }\end{array}$ & 146 & $\begin{array}{l}\text { (2) Two-lam } \\
\text { ballasts }\end{array}$ \\
\hline & 2 & ${ }^{\circ} \mathrm{F} 40 \mathrm{~T} 12$ & 1 & ELECT DIM & $\begin{array}{l}\text { Electronic Dimming (to } \\
1 \% \text { ) }\end{array}$ & 83 & \\
\hline & 3 & ${ }^{\circ} \mathrm{F} 40 \mathrm{~T} 12$ & 1.5 & ELECT DIM & $\begin{array}{l}\text { Electronic Dimming (to } \\
1 \% \text { ) }\end{array}$ & 125 & $\begin{array}{l}\text { Tandem } \\
\text { wired }\end{array}$ \\
\hline & 4 & ${ }^{\circ} \mathrm{F} 40 \mathrm{~T} 12$ & 2 & ELECT DIM & $\begin{array}{l}\text { Electronic Dimming (to } \\
1 \% \text { ) }\end{array}$ & 166 & $\begin{array}{l}\text { (2) Two-lam } \\
\text { ballasts }\end{array}$ \\
\hline
\end{tabular}

$\mathrm{RO}=$ ballast factor 70 to $85 \% \quad \mathrm{NO}=$ ballast factor 85 to $100 \% \quad \mathrm{HO}=$ ballast factor $>100 \%$ 
Table NB-10 - Fluorescent Rapid Start High Output (HO) T8 \& T12, $8 \mathrm{ft}$

Type

\begin{tabular}{|c|c|c|c|c|c|c|}
\hline \multirow[t]{2}{*}{ ype } & \multicolumn{2}{|r|}{ Lamps } & \multicolumn{3}{|c|}{ Ballasts } & \multirow{2}{*}{$\begin{array}{l}\text { System Comment } \\
\text { Watts }\end{array}$} \\
\hline & Number & Designation & Number & Designation & Description & \\
\hline \multirow{2}{*}{$\begin{array}{l}8 \text { foot Fluorescent } \\
\text { Rapid Start T8 High } \\
\text { Output ( } 86 \mathrm{~W})\end{array}$} & 1 & F96T8/HO & 1 & ELECT & Electronic & 88 \\
\hline & 2 & F96T8/HO & 1 & ELECT & Electronic & 160 \\
\hline \multirow{4}{*}{$\begin{array}{l}8 \text { foot Fluorescent } \\
\text { Rapid Start T12 High } \\
\text { Output ("Energy- } \\
\text { Saving" 95W) }\end{array}$} & 1 & F96T12/HO/ES & 1 & MAGSTD & Mag. Stand. & 125 \\
\hline & 2 & F96T12/HO/ES & 1 & MAG STD** & Mag. Stand. & 227 \\
\hline & 2 & F96T12/HO/ES & 1 & MAG. & Mag. Energy Efficient & 208 \\
\hline & 2 & F96T12/HO/ES & 1 & ELECT & Electronic & 170 \\
\hline \multirow{5}{*}{$\begin{array}{l}8 \text { foot Fluorescent } \\
\text { Rapid Start T12 High } \\
\text { Output ("Stand." 110W) }\end{array}$} & 1 & $\mathrm{~F} 96 \mathrm{~T} 12 / \mathrm{HO}$ & 1 & MAG STD & Mag. Stand. & 140 \\
\hline & 2 & $\mathrm{~F} 96 \mathrm{~T} 12 / \mathrm{HO}$ & 1 & MAG STD ${ }^{\star *}$ & Mag. Stand. & 252 \\
\hline & 2 & $\mathrm{~F} 96 \mathrm{~T} 12 / \mathrm{HO}$ & 1 & MAG. & Mag. Energy Efficient & 237 \\
\hline & 1 & $\mathrm{~F} 96 \mathrm{~T} 12 / \mathrm{HO}$ & 1 & ELECT & Electronic & 119 \\
\hline & 2 & $\mathrm{~F} 96 \mathrm{~T} 12 / \mathrm{HO}$ & 1 & ELECT & Electronic & 205 \\
\hline \multirow{2}{*}{$\begin{array}{l}8 \text { foot Fluorescent } \\
\text { Rapid Start T12 Very } \\
\text { High Output ("Energy- } \\
\text { Saving" 195W) }\end{array}$} & 1 & F96T12/NHO/ES & 1 & MAG STD & Mag. Stand. & 200 \\
\hline & 2 & F96T12/NHO/ES & 1 & MAG STD & Mag. Stand. & 325 \\
\hline \multirow{2}{*}{$\begin{array}{l}8 \text { foot Fluorescent } \\
\text { Rapid Start T12 Very } \\
\text { High Output ("Stand." } \\
215 \text { W) }\end{array}$} & 1 & Stand.96T12NHO & 1 & $\begin{array}{l}\text { MAG } \\
\text { STAND. }\end{array}$ & Mag. Stand. & 230 \\
\hline & 2 & Stand.96T $12 \mathrm{NHO}$ & 1 & $\begin{array}{l}\text { MAG } \\
\text { STAND. }\end{array}$ & Mag. Stand. & 440 \\
\hline
\end{tabular}

$\mathrm{RO}=$ ballast factor 70 to $85 \% \quad \mathrm{NO}=$ ballast factor 85 to $100 \% \quad \mathrm{HO}=$ ballast factor $>100 \%$

Table NB-11 - Fluorescent Instant Start (single pin base "Slimline") T12, $4 \mathrm{ft}$

\begin{tabular}{|c|c|c|c|c|c|c|}
\hline \multirow[t]{2}{*}{ Type } & \multicolumn{2}{|r|}{ Lamps } & \multicolumn{3}{|c|}{ Ballasts } & \multirow{2}{*}{$\begin{array}{l}\text { System } \\
\text { Watts }\end{array}$} \\
\hline & Number & Designation & Number & Designation & Description & \\
\hline \multirow{2}{*}{$\begin{array}{l}4 \text { foot Fluorescent } \\
\text { Slimline Energy-Saving } \\
\text { T12 }(32 \mathrm{~W})\end{array}$} & 1 & Stand.48T12/ES & 1 & MAG STAND. & Mag. Stand. & 51 \\
\hline & 2 & Stand.48T12/ES & 1 & MAG STAND. & Mag. Stand. & 82 \\
\hline \multirow{2}{*}{$\begin{array}{l}4 \text { foot Fluorescent } \\
\text { Slimline Stand. Stand. } \\
(39 W)\end{array}$} & 1 & Stand. $48 \mathrm{~T} 12$ & 1 & MAG Stand. & Mag. Stand. & 59 \\
\hline & 2 & Stand.48T12 & 1 & MAG Stand. & Mag. Stand. & 98 \\
\hline
\end{tabular}

RO = balast factor 70 to $85 \%$ NO ballost factor 85 to $100 \%$


Table NB-12 - Fluorescent Instant Start (single pin base "Slimline") T8 \& T12, 8 ft.

Lamps Ballasts

System Comment

Watts

\begin{tabular}{|c|c|c|c|c|c|c|c|}
\hline & & & & & & & \\
\hline & Number & Designation & Number & Designation & Description & & \\
\hline \multirow{6}{*}{$\begin{array}{l}8 \text { foot Fluorescent T8 } \\
\text { Slimline (59W) }\end{array}$} & 1 & F96T8 & 1 & MAG. & Mag. Stand. & 58 & \\
\hline & 2 & F96T8 & 1 & MAG. & Mag. Stand. & 120 & \\
\hline & 2 & F96T8 & 1 & ELECT NO & $\begin{array}{l}\text { Electronic Normal } \\
\text { Output }\end{array}$ & 110 & \\
\hline & 1 & F96T8 & 1 & ELECT HO & Electronic High Output & 72 & $\mathrm{BF} \sim 1.10$ \\
\hline & 2 & F96T8 & 1 & ELECT HO1 & Electronic High Output & 140 & $\mathrm{BF} \sim 1.10$ \\
\hline & 2 & F96T8 & 1 & ELECT HO2 & Electronic High Output & 151 & $\mathrm{BF} \sim 1.20$ \\
\hline \multirow{5}{*}{$\begin{array}{l}8 \text { foot Fluorescent T12 } \\
\text { Slimline ("Energy- } \\
\text { Saving" } 60 \mathrm{~W} \text { ) }\end{array}$} & 1 & F96T12/ES & 1 & MAG STD & Mag. Stand. & 74 & \\
\hline & 2 & F96T12/ES & 1 & MAG STD ${ }^{\star *}$ & Mag. Stand. & 131 & \\
\hline & 2 & F96T12/ES & 1 & MAG. & Mag. Energy Efficient & 112 & \\
\hline & 1 & F96T12/ES & 1 & ELECT & Electronic & 70 & \\
\hline & 2 & F96T12/ES & 1 & ELECT & Electronic & 107 & \\
\hline \multirow{5}{*}{$\begin{array}{l}8 \text { foot Fluorescent T12 } \\
\text { Slimline ("Stand." } 75 \mathrm{~W} \text { ) }\end{array}$} & 1 & F96T12 & 1 & MAG STD & Mag. Stand. & 92 & \\
\hline & 2 & F96T12 & 1 & MAG STD ${ }^{\star \star}$ & Mag. Stand. & 158 & \\
\hline & 2 & F96T12 & 1 & MAG. & Mag. Energy Efficient & 144 & \\
\hline & 1 & F96T12 & 1 & ELECT & Electronic & 85 & \\
\hline & 2 & F96T12 & 1 & ELECT & Electronic & 132 & \\
\hline
\end{tabular}

$\mathrm{RO}=$ ballast factor 70 to $85 \% \quad \mathrm{NO}=$ ballast factor 85 to $100 \% \quad \mathrm{HO}=$ ballast factor $>100 \%$

Appendix NB - Illuminance Categories and Luminaire Power 
Table NB-13 - High Intensity Discharge

\begin{tabular}{|c|c|c|c|c|c|c|c|}
\hline \multirow[t]{2}{*}{ Type } & \multicolumn{2}{|r|}{ Lamps } & \multicolumn{3}{|c|}{ Ballasts } & \multirow{2}{*}{$\begin{array}{l}\text { System } \\
\text { Watts }\end{array}$} & \multirow[t]{2}{*}{ Comment } \\
\hline & Number & Designation & Number & Designation & Description & & \\
\hline \multirow[t]{8}{*}{ Mercury Vapor } & 1 & $\mathrm{H} 40$ & 1 & MAG STD & Mag. Stand. & 51 & \\
\hline & 1 & $\mathrm{H} 50$ & 1 & MAG STD & Mag. Stand. & 63 & \\
\hline & 1 & $\mathrm{H} 75$ & 1 & MAG STD & Mag. Stand. & 88 & \\
\hline & 1 & $\mathrm{H} 100$ & 1 & MAG STD & Mag. Stand. & 119 & \\
\hline & 1 & $\mathrm{H} 175$ & 1 & MAG STD & Mag. Stand. & 197 & \\
\hline & 1 & $\mathrm{H} 250$ & 1 & MAG STD & Mag. Stand. & 285 & \\
\hline & 1 & $\mathrm{H} 400$ & 1 & MAG STD & Mag. Stand. & 450 & \\
\hline & 1 & $\mathrm{H} 1000$ & 1 & MAG STD & Mag. Stand. & 1080 & \\
\hline \multirow[t]{28}{*}{ Metal Halide } & 1 & M35/39 & 1 & MAG STD & Mag. Stand. & 48 & \\
\hline & 1 & M35/39 & 1 & ELECT & Electronic & 44 & \\
\hline & 1 & M50 & 1 & MAG STD & Mag. Stand. & 68 & \\
\hline & 1 & M50 & 1 & ELECT & Electronic & 58 & \\
\hline & 1 & M70 & 1 & MAG STD & Mag. Stand. & 92 & \\
\hline & 1 & M70 & 1 & ELECT & Electronic & 86 & \\
\hline & 1 & M100 & 1 & MAG STD & Mag. Stand. & 122 & \\
\hline & 1 & M100 & 1 & ELECT & Electronic & 110 & \\
\hline & 1 & M125 & 1 & MAG STD & Mag. Stand. & 150 & \\
\hline & 1 & M150 & 1 & MAG STD & Mag. Stand. & 186 & \\
\hline & 1 & M150 & 1 & ELECT & Electronic & 168 & \\
\hline & 1 & M175 & 1 & MAG STD & Mag. Stand. & 205 & \\
\hline & 1 & M200 & 1 & MAG STD & Mag. Stand. & 232 & \\
\hline & 1 & $\mathrm{M} 225$ & 1 & MAG STD & Mag. Stand. & 258 & \\
\hline & 1 & M250 & 1 & MAG STD & Mag. Stand. & 295 & \\
\hline & 1 & M320 & 1 & MAG STD & Mag. Stand. & 365 & \\
\hline & 1 & M320 & 1 & MAG LR & 277v Linear Reactor & 345 & \\
\hline & 1 & M360 & 1 & MAG STD & Mag. Stand. & 422 & \\
\hline & 1 & M360 & 1 & MAG LR & 277v Linear Reactor & 388 & \\
\hline & 1 & M400 & 1 & MAG STD & Mag. Stand. & 461 & \\
\hline & 1 & M400 & 1 & MAG LR & 277v Linear Reactor & 426 & \\
\hline & 1 & M450 & 1 & MAG STD & Mag. Stand. & 502 & \\
\hline & 1 & M450 & 1 & MAG LR & $277 v$ Linear Reactor & 478 & \\
\hline & 1 & M750 & 1 & MAG STD & Mag. Stand. & 820 & \\
\hline & 1 & M900 & 1 & MAG STD & Mag. Stand. & 990 & \\
\hline & 1 & M1000 & 1 & MAG STD & Mag. Stand. & 1080 & \\
\hline & 1 & M1500 & 1 & MAG STD & Mag. Stand. & 1650 & \\
\hline & 1 & M1650 & 1 & MAG STD & Mag. Stand. & 1810 & \\
\hline
\end{tabular}




\begin{tabular}{|c|c|c|c|c|c|c|c|}
\hline \multirow[t]{2}{*}{ Type } & \multicolumn{2}{|r|}{ Lamps } & \multicolumn{3}{|c|}{ Ballasts } & \multirow{2}{*}{$\begin{array}{l}\text { System } \\
\text { Watts }\end{array}$} & \multirow[t]{2}{*}{ Comment } \\
\hline & Number & Designation & Number & Designation & Description & & \\
\hline \multirow[t]{8}{*}{ High Pressure Sodium } & 1 & S35 & 1 & MAG STD & Mag. Stand. & 44 & \\
\hline & 1 & S50 & 1 & MAG STD & Mag. Stand. & 61 & \\
\hline & 1 & $\mathrm{~S} 70$ & 1 & MAG STD & Mag. Stand. & 93 & \\
\hline & 1 & $\$ 100$ & 1 & MAG STD & Mag. Stand. & 116 & \\
\hline & 1 & $\mathrm{~S} 150$ & 1 & MAG STD & Mag. Stand. & 173 & \\
\hline & 1 & $\mathrm{~S} 200$ & 1 & MAG STD & Mag. Stand. & 240 & \\
\hline & 1 & $\mathrm{~S} 250$ & 1 & MAG STD & Mag. Stand. & 302 & \\
\hline & 1 & $\$ 400$ & 1 & MAG STD & Mag. Stand. & 469 & \\
\hline $\begin{array}{l}\text { High Pressure Sodium } \\
\text { cont. }\end{array}$ & 1 & $\mathrm{~S} 1000$ & 1 & MAG STD & Mag. Stand. & 1090 & \\
\hline \multirow[t]{6}{*}{ Low Pressure Sodium } & 1 & LPS18 & 1 & MAG STAND. & Mag. Stand. & 30 & \\
\hline & 1 & LPS35 & 1 & MAG STAND. & Mag. Stand. & 60 & \\
\hline & 1 & LPS55 & 1 & MAG STAND. & Mag. Stand. & 80 & \\
\hline & 1 & LPS90 & 1 & MAG STAND. & Mag. Stand. & 125 & \\
\hline & 1 & LPS135 & 1 & MAG STAND. & Mag. Stand. & 178 & \\
\hline & 1 & LPS180 & 1 & MAG STAND. & Mag. Stand. & 220 & \\
\hline
\end{tabular}

$\mathrm{RO}=$ ballast factor 70 to $85 \% \quad \mathrm{NO}=$ ballast factor 85 to $100 \% \quad \mathrm{HO}=$ ballast factor $>100 \%$ 
Table NB-14 - 12 Volt Tungsten Halogen Lamps Including MR16, Bi-pin, AR70, AR111, PAR36 Type

\begin{tabular}{|c|c|c|c|c|c|c|}
\hline & Lamps & & & asts & System & Comment \\
\hline Number & Designation & Number & Designation & Description & & \\
\hline 1 & 20 watt lamp & 1 & ELECT & $\begin{array}{l}\text { Electronic Power } \\
\text { Supply }\end{array}$ & 23 & \\
\hline 1 & 25 watt lamp & 1 & ELECT & $\begin{array}{l}\text { Electronic Power } \\
\text { Supply }\end{array}$ & 28 & \\
\hline 1 & 35 watt lamp & 1 & ELECT & $\begin{array}{l}\text { Electronic Power } \\
\text { Supply }\end{array}$ & 38 & \\
\hline 1 & 37 watt lamp & 1 & ELECT & $\begin{array}{l}\text { Electronic Power } \\
\text { Supply }\end{array}$ & 41 & \\
\hline 1 & 42 watt lamp & 1 & ELECT & $\begin{array}{l}\text { Electronic Power } \\
\text { Supply }\end{array}$ & 45 & \\
\hline 1 & 50 watt lamp & 1 & ELECT & $\begin{array}{l}\text { Electronic Power } \\
\text { Supply }\end{array}$ & 54 & \\
\hline 1 & 65 watt lamp & 1 & ELECT & $\begin{array}{l}\text { Electronic Power } \\
\text { Supply }\end{array}$ & 69 & \\
\hline 1 & 71 watt lamp & 1 & ELECT & $\begin{array}{l}\text { Electronic Power } \\
\text { Supply }\end{array}$ & 75 & \\
\hline 1 & 75 watt lamp & 1 & ELECT & $\begin{array}{l}\text { Electronic Power } \\
\text { Supply }\end{array}$ & 80 & \\
\hline 1 & 100 watt lamp & 1 & ELECT & $\begin{array}{l}\text { Electronic Power } \\
\text { Supply }\end{array}$ & 106 & \\
\hline 1 & 20 watt lamp & 1 & MAG & Mag. Transformer & 24 & \\
\hline 1 & 25 watt lamp & 1 & MAG & Mag. Transformer & 29 & \\
\hline 1 & 35 watt lamp & 1 & MAG & Mag. Transformer & 39 & \\
\hline 1 & 37 watt lamp & 1 & MAG & Mag. Transformer & 42 & \\
\hline 1 & 42 watt lamp & 1 & MAG & Mag. Transformer & 46 & \\
\hline 1 & 50 watt lamp & 1 & MAG & Mag. Transformer & 55 & \\
\hline 1 & 65 watt lamp & 1 & MAG & Mag. Transformer & 70 & \\
\hline 1 & 71 watt lamp & 1 & MAG & Mag. Transformer & 76 & \\
\hline 1 & 75 watt lamp & 1 & MAG & Mag. Transformer & 81 & \\
\hline 1 & 100 watt lamp & 1 & MAG & Mag. Transformer & 108 & \\
\hline
\end{tabular}

